\title{
Comprehensive Survey on Nanobiomaterials for Bone Tissue Engineering Applications
}

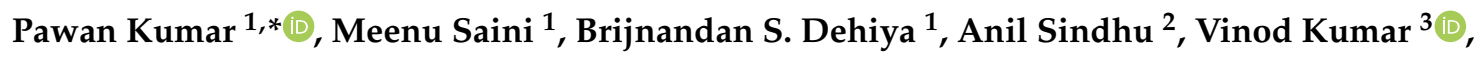 \\ Ravinder Kumar ${ }^{4, *}$, Luciano Lamberti ${ }^{5}$, Catalin I. Pruncu $6,7, * \mathbb{D}$ and Rajesh Thakur ${ }^{3}$ (D) \\ 1 Department of Materials Science and Nanotechnology, Deenbandhu Chhotu Ram University of Science \\ and Technology, Murthal 131039, India; meenu.rschmsn@dcrustm.org (M.S.); \\ drbrijdehiya.msn@dcrustm.org (B.S.D.) \\ 2 Department of Biotechnology, Deenbandhu Chhotu Ram University of Science and Technology, \\ Murthal 131039, India; sindhu.biotech@gmail.com \\ 3 Department of Bio and Nanotechnology, Guru Jambheshwar University of Science and Technology, \\ Hisar 125001, India; indoravinod2@gmail.com (V.K.); rtnano@gmail.com (R.T.) \\ 4 School of Mechanical Engineering, Lovely Professional University, Phagwara 144411, India \\ 5 Dipartimento di Meccanica, Matematica e Management, Politecnico di Bari, 70125 Bari, Italy; \\ luciano.lamberti@poliba.it \\ 6 Department of Design, Manufacturing \& Engineering Management, University of Strathclyde, \\ Glasgow G1 1XJ, UK \\ 7 Department of Mechanical Engineering, Imperial College London, London SW7 2AZ, UK \\ * Correspondence: pawankamiya@yahoo.in (P.K.); rav.chauhan@yahoo.co.in (R.K.); \\ catalin.pruncu@strath.ac.uk (C.I.P.)
}

Received: 1 September 2020; Accepted: 9 October 2020; Published: 13 October 2020

\begin{abstract}
One of the most important ideas ever produced by the application of materials science to the medical field is the notion of biomaterials. The nanostructured biomaterials play a crucial role in the development of new treatment strategies including not only the replacement of tissues and organs, but also repair and regeneration. They are designed to interact with damaged or injured tissues to induce regeneration, or as a forest for the production of laboratory tissues, so they must be micro-environmentally sensitive. The existing materials have many limitations, including impaired cell attachment, proliferation, and toxicity. Nanotechnology may open new avenues to bone tissue engineering by forming new assemblies similar in size and shape to the existing hierarchical bone structure. Organic and inorganic nanobiomaterials are increasingly used for bone tissue engineering applications because they may allow to overcome some of the current restrictions entailed by bone regeneration methods. This review covers the applications of different organic and inorganic nanobiomaterials in the field of hard tissue engineering.
\end{abstract}

Keywords: nano-biomaterials; nanotechnology; scaffolds; hard tissue engineering

\section{Introduction}

Nanobiomaterials denote nanometer-sized materials whose structures and constituents have significant and novel characteristics with a strong impact on healing and medicine [1,2]. They include metals, ceramics, polymers, hydrogels, and novel self-assembled materials [3]. Rapid developments in nanotechnology not only led to create new materials and tools for biomedical applications, but also changed the way of using these materials in science and technology [4,5].

Human bone is a dynamic tissue that can rebuild and remodel in the body throughout life [6]. The human bone is a hierarchical assembly of nano- to macro-scale organic and inorganic components involved in transmitting physio-chemical and mechano-chemical cues [7,8]. The schematic of Figure 1 
shows that normal human bone contains 30\% organic collagen fibrils and 70\% inorganic minerals [9-12], while $2 \%$ of the total volume is occupied by bone cells, osteoblasts, osteoclasts, lining cells, progenitor cells, and adipocytes $[13,14]$. Crystalline phases form $65 \%$ of the dry weight of the mineral matrix and most part of calcined fraction in calcium phosphate $[15,16]$.

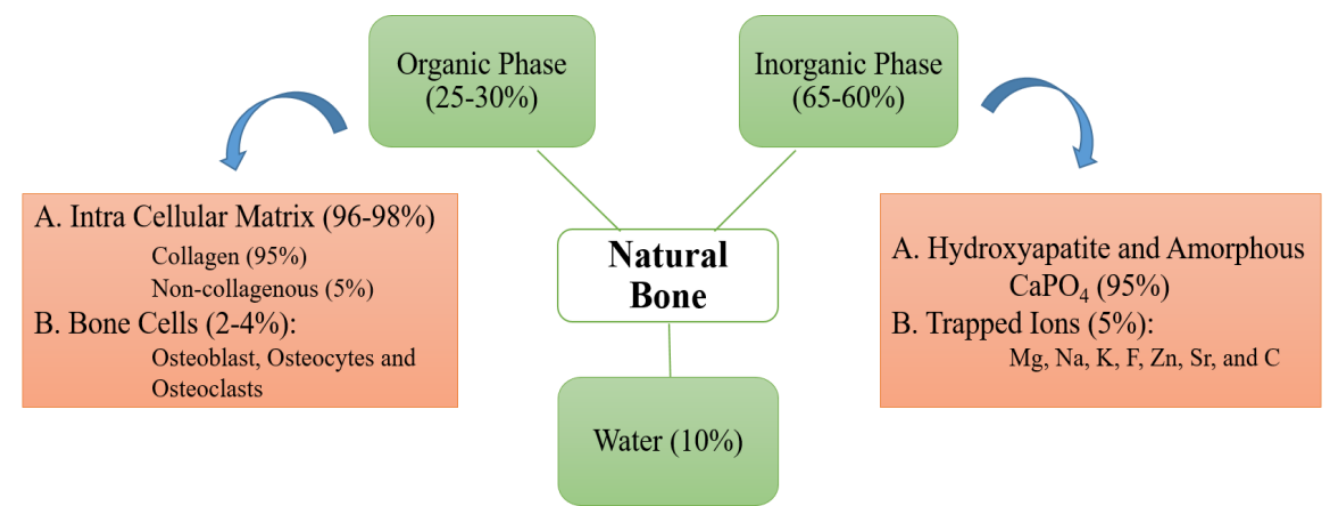

Figure 1. Composition of natural bone.

The continuously growing population and the higher complexity of human interactions have generated new bone-related diseases (e.g., bone tumors, bone infections, and bone loss). This requires effective handling and treatment for bone regeneration $[17,18]$. Tissue engineering has revolutionized orthopedic and surgical studies, providing a new direction in the field based on nanoscale surface modification to simulate properties of extracellular matrix (ECM) and new foundations of structural variables of autologous tissue $[19,20]$. Tissue engineering is used to generate, restore, and/or replace tissues and organs by using biomaterials and helps to produce similar native tissue or organ [21].

Nanotechnology solved many questions in tissue engineering by modifying regenerative strategies [22]. Biomedical applications of nanotechnology became a hot subject because different nanomaterials are utilized for the synthesis of scaffolds or implants [23,24]. These nanomaterials may be metallic [25], ceramic, or polymeric [26] with different structural forms such as tubes, rods, fibers, and spheres [27]. Various properties of materials such as physiochemical, electrical, mechanical, optical, catalytic, and magnetic properties can be improved at the nanoscale [28] and tailored to specific applications. Nanomaterials synthesized through top-down or bottom-up approaches [29] (Figure 2) have outstanding properties, which are used for biomedical applications particularly in tissue engineering [22].

Existing biomaterials often do not integrate with host tissue completely. This may cause infection and foreign body reactions that lead to implant failure [30]. Indeed, nanostructured biomaterials imitate the natural bone's extracellular matrix (ECM), producing an artificial microenvironment that promotes cell adhesion, proliferation and differentiation [31]. The specific biological, morphological, and biochemical properties of nanobiomaterials attract researchers to use them for the hard tissue engineering [32]. Nanostructured biomaterials can be used to fabricate high-performance scaffolds or implants with tailored physical, chemical, and biological properties. Several natural and synthetic nanostructured biomaterials are now available for the fabrication of scaffolds with decent bioactivity [33].

This survey article presents the most relevant applications of nanobiomaterials to bone tissue engineering, trying to highlight how organic and inorganic nanobiomaterials can deal with the above mentioned requirements on bone regeneration and the multiple challenges entailed by such a complicated subject. A broad overview of the various types of nanobiomaterials and their applications in the field of hard tissue engineering is provided. 


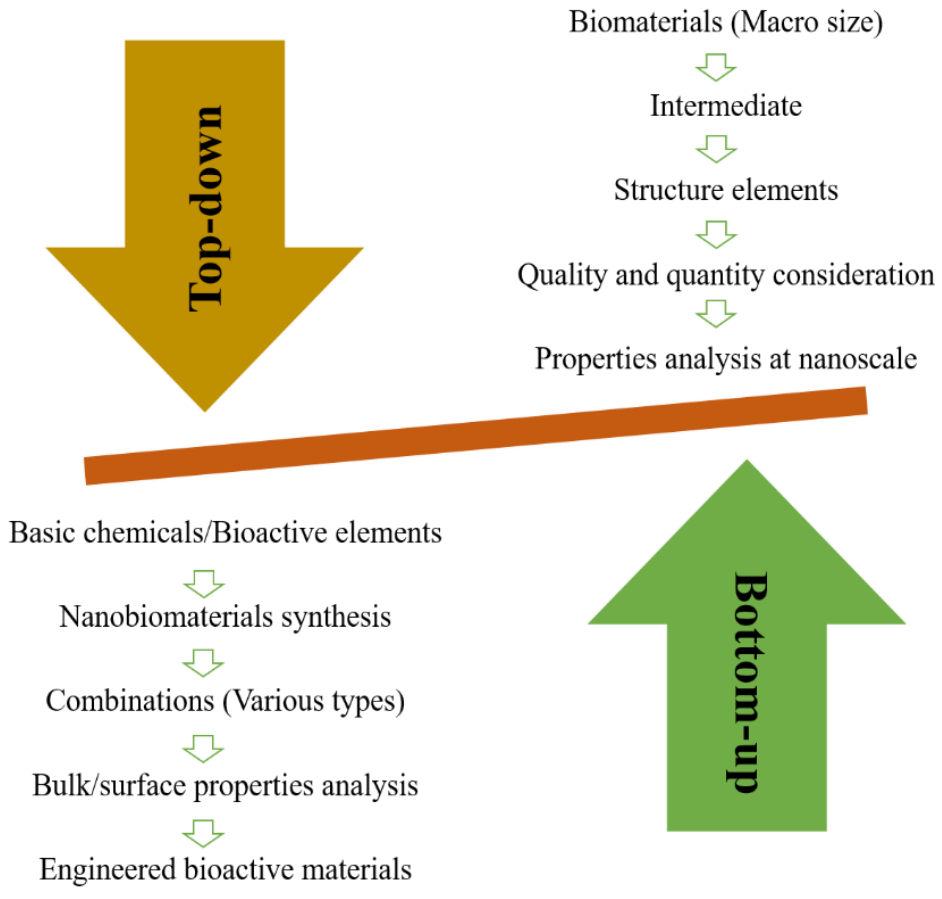

Figure 2. Design of bioactive materials based on top-down and bottom-up approaches.

Besides the introductory articles mentioned above and other general articles on topics related to nanomaterials and the different contexts where they operate, the present survey covers some 550 technical papers focusing on types, fabrication, and applications of nanobiomaterials. These articles have been selected using three widely used academic search engines: Scopus, Web of Science, and Google Scholar. For that purpose, keywords such as "tissue engineering", "bone tissue engineering", "tissue regeneration", "scaffolds", "nanomaterials", and "nanobiomaterials" as well as their combinations have been used as input for the search process. High priority is given to peer-reviewed journal articles with respect to book chapters and conference proceedings, which count for some 10 papers, less than $1.75 \%$ of the total number of surveyed articles. More detailed statistics on the articles surveyed for each topic will be reported at the end of the corresponding subsections.

The paper is structured as follows. Sections 2 and 3 describe the various types of organic and inorganic nanobiomaterials and their applications in bone tissue engineering/regenerative medicines, drug/gene delivery, anti-infection properties, coatings, scaffold fabrication, and cancer therapy; generalizing conclusions are given at the end of each section. The conclusion section summarizes the main findings of this survey.

\section{Nanobiomaterials}

Nanobiomaterials cover a wide variety of biomaterials including natural and artificial materials, used for various applications in tissue engineering [34-36]. These materials can be classified into two categories, i.e., organic nanobiomaterials and inorganic nanobiomaterials, where the former is characterized by the presence of carbon-containing constituents. Organic-inorganic hybrids are much more effective biomaterials than pure polymers, bioglasses, metals, alloys, and ceramics [37] as they try to combine best properties of constituents following the general concept of composite material. Section 2.1 will review the different types of organic nanobiomaterials, while Section 2.2 will review the different types of inorganic nanobiomaterials.

\subsection{Organic Nanobiomaterials}

Nanostructured materials have characteristics like biocompatibility, nontoxicity, and non-carcinogenicity. When used for replacement or restoration of body tissue, they are regarded as organic nanobiomaterials [38]. 
Several research groups have shifted their attention from metallic to organic nanomaterials, such as lipids, liposomes, dendrimers, and polymers including chitosan, gelatin, collagen, or other biodegradable polymers [39]. Organic materials are combinations of a few of the lightest elements, particularly hydrogen, nitrogen and oxygen, and carbon-containing chemical compounds located within living organisms [40]. Proteins, nucleic acids, lipids, and carbohydrates (the polysaccharides) are the basic types of organic materials [41].

Table 1 presents a general classification of organic nanobiomaterials and summarizes representative applications of each material in tissue engineering. The following subsections present a general description of each nanomaterial type listed in Table 1 and a detailed literature survey on the corresponding developments for tissue engineering.

Table 1. Types of organic nanobiomaterials with their applications.

\begin{tabular}{|c|c|c|c|}
\hline Types of Nanomaterials & Size (nm) & Applications & References \\
\hline Lipid & $<100$ & $\begin{array}{l}\text { Nanocarriers for anticancer } \\
\text { drug doxorubicin } \\
\text { Osteoblastic bone formation } \\
\text { Osteoporosis treatment }\end{array}$ & [42-45] \\
\hline Liposome & $>25$ & $\begin{array}{c}\text { High encapsulation of hydrophilic } \\
\text { drug (drug delivery) } \\
\text { Growth factor delivery } \\
\text { Therapeutic gene delivery } \\
\text { Used as a template }\end{array}$ & [46-48] \\
\hline Dendrimers & $<10$ & Multidrug delivery system & {$[46,49,50]$} \\
\hline Chitosan & $20-200$ & $\begin{array}{l}\text { Nano/microparticles or fiber-based scaffolds } \\
\text { Drug delivery } \\
\text { Support chondrocyte adhesion } \\
\text { Implant coating }\end{array}$ & [51-55] \\
\hline Collagen & - & $\begin{array}{l}\text { Drug Delivery } \\
\text { Scaffolds }\end{array}$ & [56] \\
\hline Gelatin & $<200$ & $\begin{array}{l}\text { Bone scaffold systems formation } \\
\text { Drug-loaded gelatin nanoparticles (DGNPs) } \\
\text { Promote cell growth }\end{array}$ & {$[24,57,58]$} \\
\hline Poly(lactic-co-glycolic acid) PLGA & $100-250$ & $\begin{array}{c}\text { Drug delivery } \\
\text { Scaffold system } \\
\text { Nanostructured Film } \\
\text { Enhanced cell attachment and growth }\end{array}$ & [59-62] \\
\hline Carbon Nanotubes & $20-100$ & $\begin{array}{c}\text { Drug delivery } \\
\text { Biosensing } \\
\text { Mechanically improved scaffold fabrication } \\
\text { Enhanced rat brain neuron response }\end{array}$ & [63-66] \\
\hline
\end{tabular}

\subsubsection{Lipids}

Lipids are small hydrophobic or amphiphilic molecules [67]. They can be classified as fatty lipids of acylglycerol, phospholipids such as glycerides, seduction lipids, sterols, demonstrations of lipids played, lipids, and polylactide Kane [68]. Lipids are essential agents for the physiological and pathophysiological functioning of cells [69]. Generally, 10-1000 $\mathrm{nm}$ sized spherical lipid nanoparticles are synthesized [70]. All organisms consist of lipids as basic components, among other ingredients. The use of these lipids in pharmaceutical and biomedical fields can solve the problem of biocompatibility and biodegradation [71]. Besides liposomes (lipids arranged in the formation), other unique structures (e.g., hexagonal, spongy, solid structure, etc.) resulting from lipid polymorphisms also are available $[72,73]$. The latter have better stability and production efficiency than liposomes [48]. Lipid nanocarriers are better than polymeric nanoparticles (NPs) in terms of biocompatibility and lower toxicity, production cost and scalability, and encapsulation efficiency of highly lipophilic actives [74,75]. Lipid nanocarriers such as solid lipid nanoparticles (SLN) [76], nanostructured lipid carriers (NLC) [77], lipid nanocapsules 
(LNC) [78], and drug-lipid conjugates [79] are used for various administration routes (i.e., parenteral, oral, and topical ones) [80]. Lipid polymer hybrid nanoparticles (LPHNs) can also be used in the area of bioimaging agents for medicinal diagnostics as delivery vehicles like iron oxide, quantum dots (QDs) fluorescent dyes, and inorganic nanocrystals [81].

\subsubsection{Liposomes}

Liposomes were discovered in the mid-1960s by A. D. Bangham [82]. The vesicle of the liposome is easily fabricated in a laboratory and made of one or more phospholipid bilayers [83] (Figure 3). These are self-assembled versatile particles with diameters ranging from nanometer to micrometer scale [84]. Resembling lipid cell membranes, the nature of phospholipid depends on the length of fatty acid chains [48]. They have the ability to encapsulate and carry hydrophobic aqueous agents [82]. They exhibit many advantages over other carrier systems $[85,86]$.

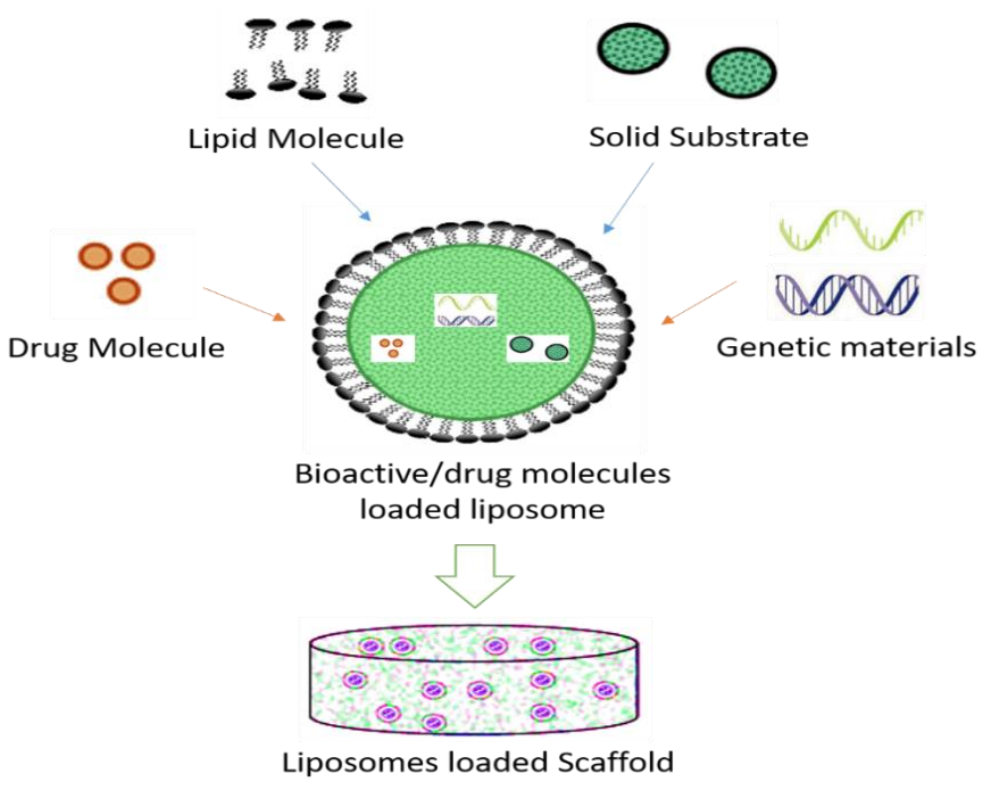

Figure 3. Fabrication of liposome loaded scaffold.

Bone morphogenetic protein-2 (BMP-2) is one of the most potent proteins in bone regeneration [87]. For this reason, encapsulation of BMP-2 in nanomaterials has attracted great interest. BMP-2-loaded liposomal-based scaffolds may possess better osteoinductivity and bone formation ability [88].

Liposomes can carry drugs directly to the site of action and sustain their levels without causing toxicity for long periods [89]. By changing the composition of lipids, liposome properties can change. Some liposome preparations for anticancer drugs have successfully released on the market by acquiring FDA's approval [83]. Gentamycin- and vancomycin-integrated liposome-loaded particles are employed for manufacturing of scaffolds [90]. The integration of bioactive aspirin into a liposome delivery system would have a beneficial impact on stem cell osteoblast differentiation [91]. The initial drug amount and the chemical and physical drug properties are considerable factors for the encapsulation efficiency [92]. DOXIL ${ }^{\circledR}$, the first FDA-approved nanodrug, which consists of liposomes encapsulating doxorubicin, was prepared by this remote loading method [93]. This method can also be used for preparing liposomes encapsulating other drugs such as daunorubicin and vincristine [94]. Liposomal systems are highly used despite being the oldest of the non-viralgene-delivery vehicles [95]. Scaffolds used as delivery vehicles for bioactive agents offer many advantages such as enhanced and extended gene expression, and the ability to control a localized delivery of cargo [96] (see Figures 3 and 4). 


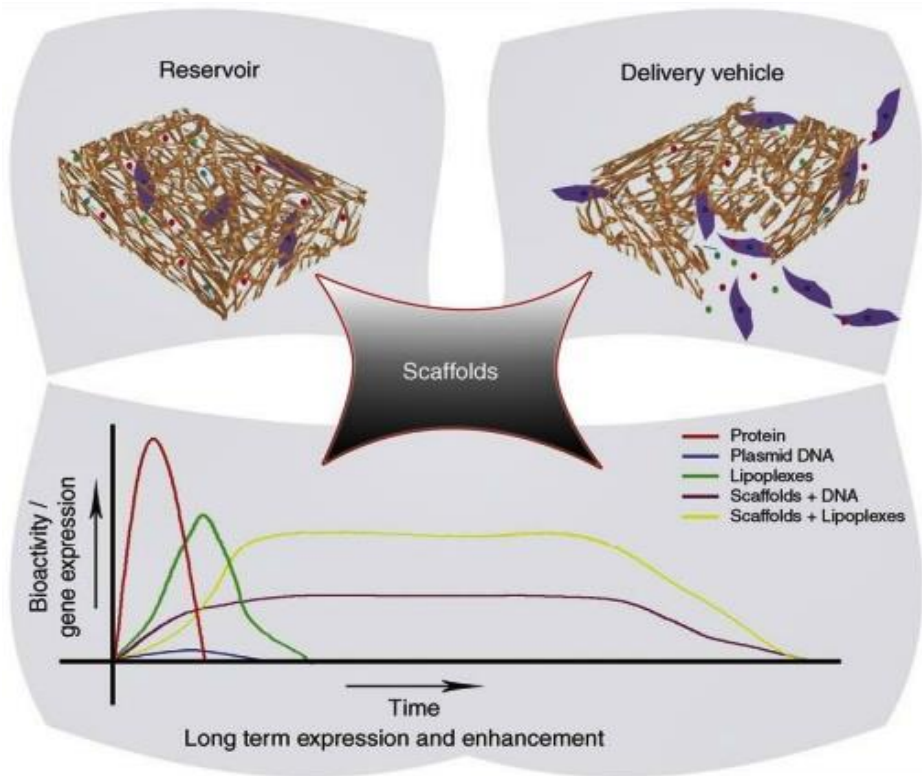

Figure 4. Schematic depiction of the role of tissue-engineered scaffolds in gene delivery [96] (adapted with permission from Elsevier (C) 2009).

\subsubsection{Dendrimers}

Dendrimers are the newest class of highly-defined macromolecules, which differs from simple polymers by branching at each repeating unit [97]. Their step-by-step controlled synthesis is used worldwide for molecular chemistry, while their repeating structure made of monomers relate them to the world of polymers $[98,99]$. The repetitively branched nanometer-scale dimension of dendrimers is an ideal candidate for a variety of tissue engineering [100], molecular imaging [101], and drug delivery [102] applications. Dendrimers can be a main component of scaffolds mimicking cross-linkers, chemical surface modifiers, and charge modifiers, as well as natural extracellular matrices [103].

The combination of dendrimers with other conventional structural polymers, such as proteins, carbohydrates and linear synthetic polymers, leads to obtain new physical, mechanical and biochemical properties of hybrid structures $[100,104]$. The center of dendrimer may be composed of polypropylimine (PPI), di-aminobutyl (DAB), polyamidoamine (PAMAM), and ethylenediamine (EDA), along with various surface residues such as amine, carboxyl, and alcoholic groups [105]. A dendrimer can be synthesized for particular use in different parts with controlled properties like solubility and thermal stability [106].

Dendrimer-drug conjugation is a better approach to the encapsulation of cytotoxic pharmaceuticals. In this way, numerous cytotoxic and anticancer drugs, and targeted individuals such as monoclonal antibodies, peptides, and folic acid, can be conjugated to a single dendrimer molecule [107]. The drug is covalently conjugated to the dendrimer rather than complexed (Figure 5) [108] and these conjugates are relatively more stable.

Dendrimers are a good choice for hydrophobic moieties and poorly water-soluble drugs [109]. PAMAM dendrimer/DNA complexes were employed to encapsulate functional fast biodegradable polymer films used for substrate-mediated gene delivery [110].

The physicochemical characteristics, such as solubility and pharmacokinetics, of dendrimers are better than those of linear polymers. Therefore, dendrimers are ideal candidates for incorporation into scaffolds used for tissue engineering applications [111,112]. A few scaffolds were fabricated with dendrimers such as poly(caprolactone) chains conjugated to a poly(L-lysine) dendritic core to fabricate an HA-composite [113], linear PCL/n-HA hybrids [114], N-hydroxy succinimide/1-ethyl-3-(3-dimethyl aminopropyl) carbodiimide (NHS/EDC) cross-linked scaffold [115], and dexamethasone carboxymethyl chitosan/PAMAM [116] for in vitro bone regeneration. 


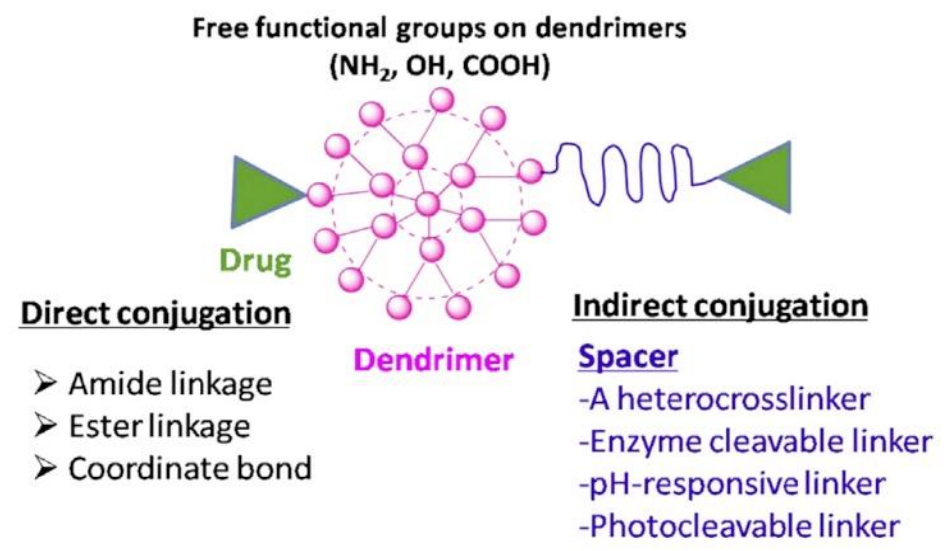

Figure 5. Structure of a typical dendrimer-drug conjugate (Reused with permission from Elsevier [108].)

\subsubsection{Polymeric Nanomaterials}

Polymeric nanoparticles of size range $10 \mathrm{~nm}$ to $1 \mu \mathrm{m}$ are the most advanced noninvasive approaches to tissue engineering and drug delivery applications [117]. They are comprised of repeating units of chain-like macromolecules with multiple structures and compositions [118]. In general, polymeric nanoparticles can be used for different applications by changing the physicochemical properties of nanoparticles. Polymers are differently processed to produce nanofibers [119], spherical nanoparticles [120] and polymeric micelles [121] for specific applications.

There are several techniques to synthesize polymer-based nanoparticles, applied in tissue engineering [122]. Gelation [123], emulsion-solvent evaporation [124], nanoprecipitation [125], salting-out [122], and desolvation process [126] are generally preferred for natural polymers, like proteins and polysaccharides. Similar to other nanoparticle systems, polymer-based nanoparticles or nanocomposites can be functionalized to perform active targeting [127].

Polymeric nanoparticles alter and may enhance the pharmacokinetic and pharmacodynamic properties used for various drug types because they show controlled and sustained release properties [128]. They offer a variety of benefits ranging from the administration of non-soluble drugs to protection of unstable compounds [129]. These nanoparticles can be loaded with therapeutic or bioactive molecules (Figure 6) either by dispersion or adsorption within the polymer matrix, or encapsulation $[130,131]$.

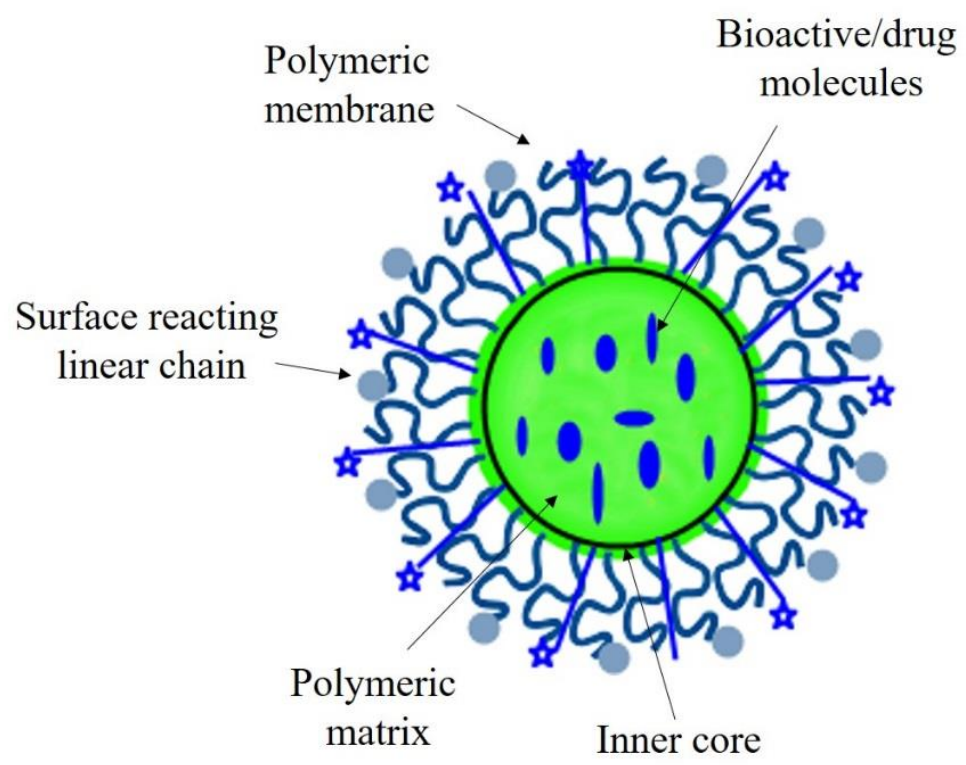

Figure 6. Bioactive/drug molecules loaded polymeric nanoparticles. 
Drug release may occur directly from nanoparticles through diffusion and polymeric nanoparticles may dissociate into monomers [132]. Polymers used for nanoparticle fabrication should be degradable via enzymatic or non-enzymatic routes under common metabolic pathways [133,134]. Drug-containing polymeric nanoparticles must be stable during migration to the plasma, that is, at almost neutral $\mathrm{pH}$ [135].

Chitosan, collagen, gelatin, hyaluronic acid, alginate, and albumin are representative examples of natural biopolymers $[136,137]$. Polymeric nanoparticles are one of the fastest-growing platforms for the applications in tissue engineering because of their biocompatibility, biodegradability, low cytotoxicity, high permeation, ability to deliver poorly soluble drugs, and retaining bioactivity after degradation [117]. Some newly designed polymeric nanoparticles are sensitive to $\mathrm{pH}$, temperature, oxidizing/reducing agents, and magnetic field which support a high efficiency and specificity for tissue engineering applications $[138,139]$. Due to good biocompatibility and adjustable chemical composition, and their ability to reorganize, polymeric nanoparticles are very promising as nanobiomaterials for the fabrication of scaffolds or bone substitutes [140]. Plasma protein-based nanoparticles have shown high biodegradability, bioavailability, long in vivo half-lives, and long shelf lives without any toxicity. Blood plasma is a complex mixture of 100,000 proteins, but only two of these proteins have been used in drug administration and tissue regeneration [141,142].

\section{Chitosan}

Chitosan is a natural and nontoxic linear biopolymer synthesized from alkaline $\mathrm{N}$-deacetylation of chitin [143]. It can be extracted from exoskeleton of crustacean shells (i.e., crabs and shrimps) some microbes, yeast, and fungi [144]. It has different molecular weights and is soluble in various organic solutions at $\mathrm{pH} 6.5$ and below. The shape of the chitosan nanoparticles is affected by the degree of deacetylation $[145,146]$. The presence of amine and hydroxyl group leads the use of these compounds in many research areas $[147,148]$. Chitosan has outstanding biochemical properties, making it very attractive for applications in many areas including tissue engineering and/or regenerative medicine (Figure 7) [149]. Chitosan nanoparticles carry well therapeutic agents and biomolecules because of their high biocompatibility and biodegradability. Because of their small size, they can pass through biological barriers in vivo and deliver the drugs at the targeted site [150].

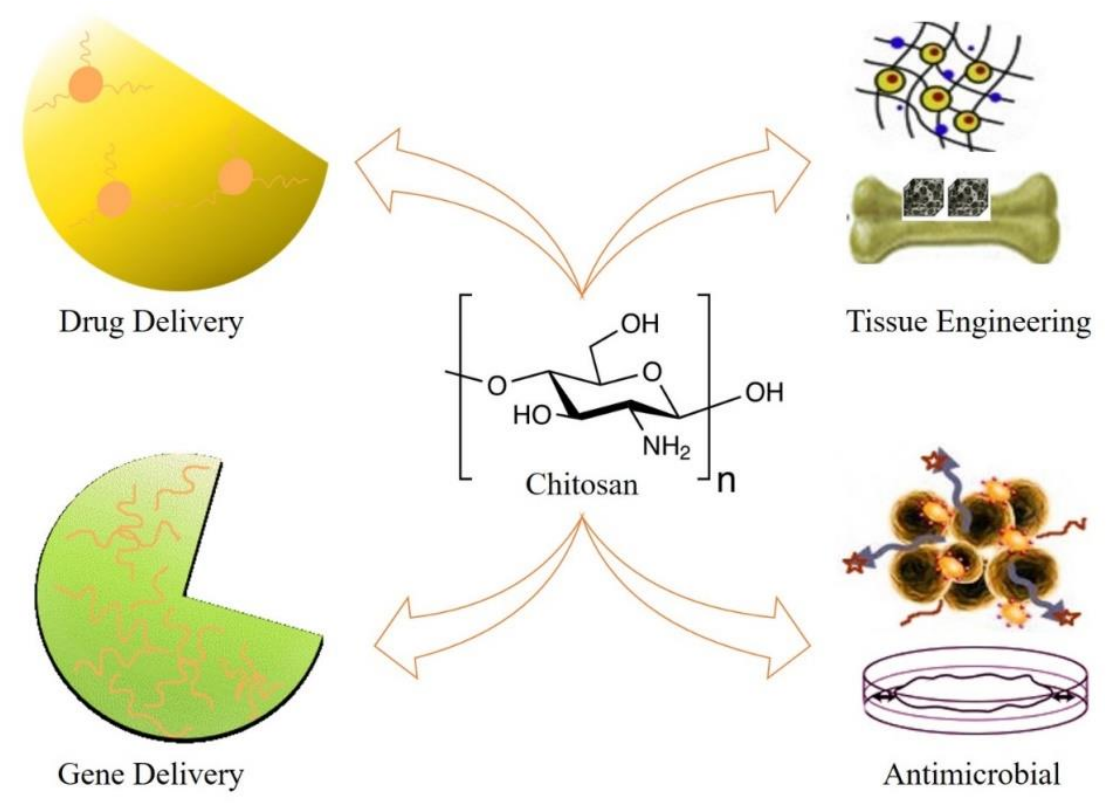

Figure 7. Prospective applications of chitosan. 
Applications of Chitosan: Scaffolds prepared from chitosan and ceramics, especially hydroxyapatite, may have superior osteocond uctive properties [151]. Bone morphogenetic protein-2 (BMP-2)-loaded chitosan nanoparticles used for the coating of Ti implants were selected in order to examine bone regeneration in mice [55]. Chitosan and growth factor (BMP-7) were used to functionalize a thick electrospun poly( $\varepsilon$-caprolactone) nanofibrous implant (from $700 \mu \mathrm{m}$ to $1 \mathrm{~cm}$ thick), which produced a fish scale-like chitosan/BMP-7 nano-reservoir. This nanofibrous implant mimicked the extracellular matrix and enabled in vitro colonization and bone regeneration [152]. There, the polycationic nature of chitosan entails an antimicrobial behavior at nanoscale [153]. Besides the orthodontic field, there are relevant applications of chitosan in skin healing, nerve regeneration, and oral mucosa [39]. Nanobioglass incorporated chitosan-gelatin scaffolds showed excellent cytocompatibility and ability to accelerate the crystallization of bone-like apatite in vitro [154,155]. The nanocomposite of chitosan/hydroxyapatite-zinc oxide (CTS/HAp-ZnO) supporting organically modified montmorillonite clay (OMMT) was synthesized and used for hard tissue engineering applications [156]. BMP-2 and BMP-7 loaded poly(3-hydroxybutyrate-co3-hydroxyvalerate) nanocapsules were used for the fabrication of chitosan-poly(ethylene oxide) scaffolds [157]. Mili et al. [158] used nerve growth factor (NGF) loaded chitosan nanoparticles for neural differentiation of canine mesenchymal stem cells. Freeze-dried nano- $\mathrm{TiO}_{2} /$ chitosan scaffolds showed high biocompatibility and antibacterial effects [159]. Chitosan-poly(vinyl alcohol)-gum tragacanth (CS/PVA/GT) hybrid nanofibrous scaffolds showed $20 \mathrm{MPa}$ ultimate tensile strength and supported L929 fibroblast cells growth [160]. Collagen-chitosan-calcium phosphate microsphere scaffolds fused with glycolic acid did not show relevant differences in their degradation, cytocompatibility, porosity, and Young's modulus [160,161].

\section{Collagen}

The main constituents of living human bone are collagen type-1 (protein) and calcium phosphate or hydroxyapatite (mineral) [162]. Collagen is the major structural protein of the soft and hard tissues in living organisms [163]. It can have a significant role in preserving biological and structural integrity of extracellular matrix (ECM) [164]. It is a versatile material that is widely used in the biomedical field (Figure 8) due to advantages including high biocompatibility and biodegradability [165]. Collagen is mainly used as a carrier for drug delivery as well as osteogenic and bone filling material [166]. Collagen matrix was also used to deliver gene promoting bone synthesis [167]. Collagen with recombinant human bone morphogenetic protein-2 was used to monitor bone formation [168].

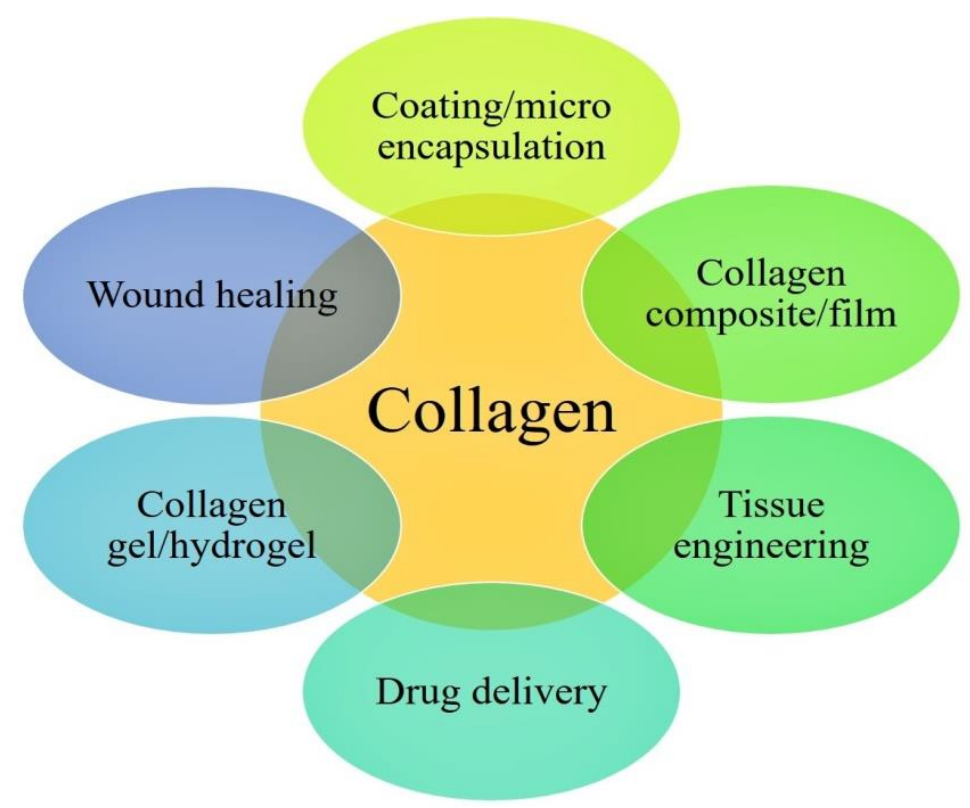

Figure 8. Biomedical applications of collagen. 
Bone morphogenic protein (BMP)-loaded collagen activates osteoinduction in the host tissue [169]. Collagen-based nanospheres/nanoparticles can be used as a systematic delivery carrier for various therapeutic agents or biomolecules [166]. As collagen type-I and hydroxyapatite are a basic part of the bone, hydroxyapatite and collagen were used to fabricate scaffolds that enhance osteoblast differentiation and accelerate osteogenesis [170].

Collagen-based biomaterials in various formats such as 3-D scaffolds have been employed for tissue engineering [171]. The combination of collagen with elastin was successfully fabricated and in vitro tests proved the adhesion and proliferation of cells without any cytotoxicity [172]. Collagen-based inks were used for 3D bioprinting employed for tissue repairing and scaffold fabrication. The collagen-based ink was extruded with a temperature stage of $-40^{\circ} \mathrm{C}$, followed by freeze-drying and cross-linking by using 1-ethyl-(3-3-dimethylaminopropyl) hydrochloride solution [173].

Gelatin

Gelatin represents a derivative of collagen, extracted by collagen hydrolysis from the skin, bones, and/or connective tissues of animals. It is a cost effective, biocompatible, and biodegradable polymer, which supports cross-linking of functional groups. Gelatin is a versatile polymer that is known for his wealth merits [174]. Pharmaceutical or medical grade gelatin has fragility and transparency for tablet coatings, suspensions, capsule formulations, and nano-formulations (Figure 9).

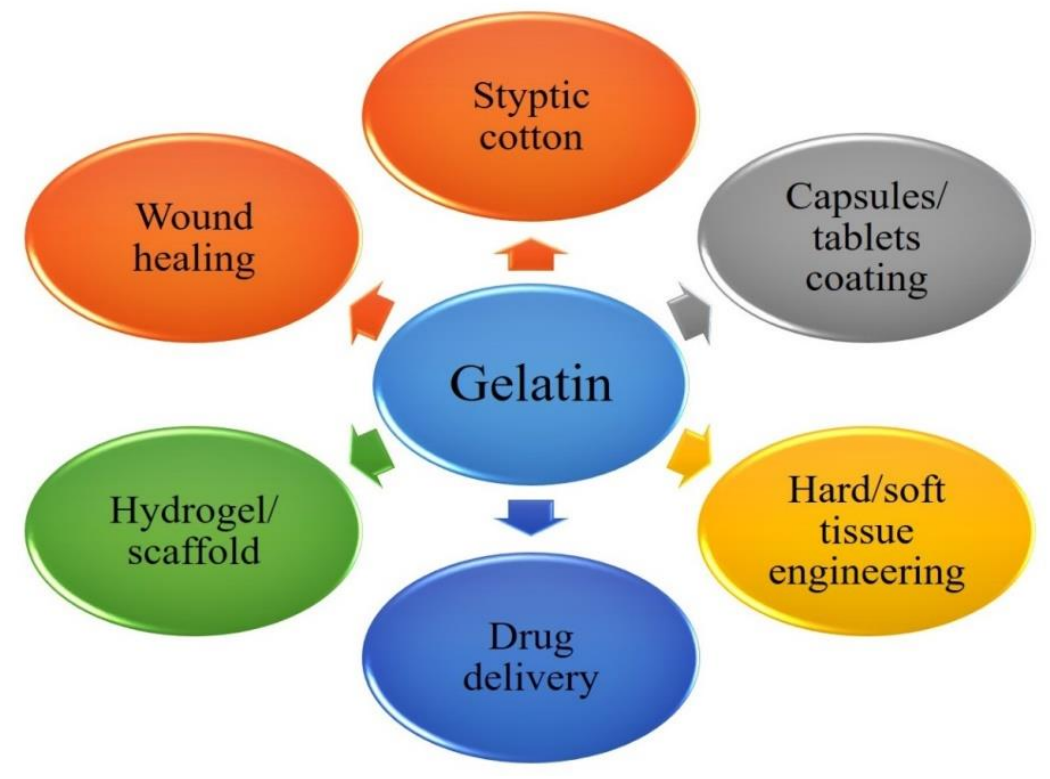

Figure 9. Biomedical and pharmaceutical uses of gelatin.

Because of their great biocompatibility, the injected gelatin-loaded nanoparticles have been reported in the skeletal system $[24,175,176]$. It is a polyampholyte at pH 9 (gelatin A) and pH 5 (gelatin B). Gelatin nanoparticles are used as a biomaterial for the delivery of biomolecules and therapeutic agents [177]. However, digestive process of gelatin showed low antigenicity, with the formation of harmless metabolic products. In order to prevent infectious disease transmission, genetic engineering approaches were used for the production of human recombinant gelatin [178,179].

At the nanoscale, gelatin shows high biocompatibility, biodegradability, and low immunogenicity [180]. The presence of a higher number of functional groups on polymer backbone helps with crosslinking and chemical modification [181]. The cross-linking is necessary to stabilize the macromolecular structure of gelatin is not stable at normal body temperature due to the low melting temperature [182,183].

Gelatin methacryloyl (GelMA) hybrid hydrogel demonstrated a wide range of tissue engineering applications. When exposed to light irradiation, GelMA scaffolds convert into hydrogels with tunable mechanical properties [184]. Gelatin enables therapeutic cell adhesion without comprising cell 
phenotypes [185]. Porous HA-gelatin microparticles (1 to $100 \mu \mathrm{m})$ support human osteoblast-like Saos-2 cells growth and cell delivery [186]. A mechanically strong gelatin-silk hydrogel composite was prepared by direct blending of gelatin with amorphous Bombyxmori silk fibroin (SF) [187]. Gelatin coated polyamide (PA) scaffold showed good biomechanical, cell attachment, and wound healing characteristics while being transplanted to nude rats [188]. Poly(lactide-co-glycolide) (PLGA)-gelatin fibrous scaffolds possess the highest Young's modulus $(770 \pm 131 \mathrm{kPa})$ and tensile strength $(130 \pm 7 \mathrm{kPa})$ [189]. Methacrylamide-modified gelatin (GelMOD) 3D CAD scaffolds showed excellent stability in culture medium and support porcine mesenchymal stem cell adhesion and subsequent proliferation [190].

Gelatin-based microcarriers used embryonic stem cell delivery for the applications in tissue engineering [191]. The magnetic nanoparticles were assembled with magnetic gelatin membranes to produce 3D multilayered scaffolds (Figure 10), which are used for controlled distribution of magnetically labeled stem cells [192].

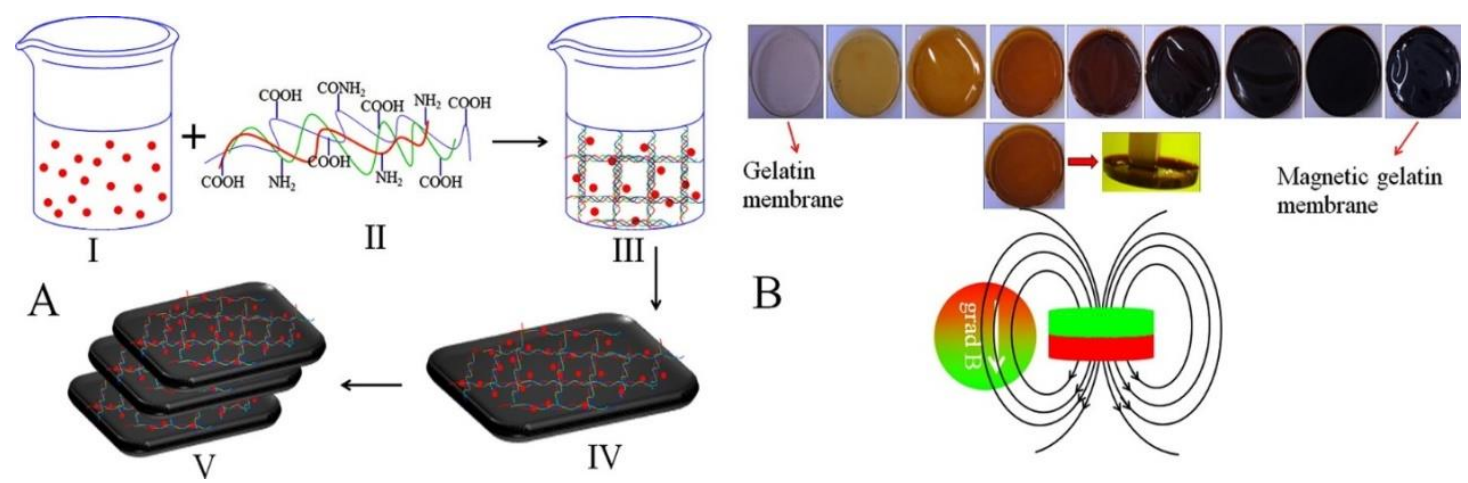

Figure 10. (A) Fabrication of a multilayered magnetic gelatin scaffold. (B) Magnetic gelatin membranes with increasing MNPs concentration from left to right as well as a representation of the properties of the magnetic gradient. (Adapted with permission from (C) 2015 American Chemical Society [192]).

Poly (Lactic-co-glycolic) acid (PLGA)

PLGA is considered as one of the most efficient tissue engineering materials due to its (i) high biocompatibility, (ii) biodegradability, (iii) potential to interact with biological materials, and (iv) clinical use approved by FDA [193]. Biodegradable biomolecule-loaded PLGA nanoparticles can be used for the preparation of a drug delivery system, which can be further utilized in scaffold fabrications [194-196]. These nanoparticles may increase the mechanical properties of the scaffolds but decrease swelling behavior without changing the morphology of the scaffold [197]. Afterward, this system is effective to prepare a controlled release platform for model drugs that favors the bio-distribution and development of clinically relevant therapies [198]. Different methods such as gas foaming [199], porogen leaching [200], solid freedom fabrication [201], and phase separation [202] can be used for PLGA scaffolds fabrication.

\subsubsection{Carbon Nanostructures}

Carbon nanomaterials are great candidate materials for bone tissue engineering due to their conductivity, lightweight, stability and strength [203]. Nanostructures such as fullerenes, carbon nanotubes, carbon nanofibers, and graphene are the most common structures (Figure 11) [204,205].

Han et al. [205] pointed out that carbon is biocompatible and can be used in many clinical applications, such as prosthetic heart valves. However, a pure form of carbon nanomaterials cannot be used as a substrate for bone tissue [206]. Therefore, carbon-based materials are used in combined form to fabricate scaffolds [207]. Carbon nanostructures doped or reinforced compositions became more popular due to their high performance and compatibility with bone tissues [203]. 
Carbon nanofibers (CNF) are cylindrical or conical structures of various diameters and lengths. The interior structure of the CNF contains an improved layout of graphene sheets. Graphene is a single-layer two-dimensional material composed of long-edged reactive carbon atoms. Graphene leaves are characterized by stable dispersion and orientation of nanofillers [208-210].

Carbon nanotubes (CNT) enhance mechanical and electrical properties, which helps to generate innovative products. CNTs are one of the ideal and favorable materials used for designing novel polymer composites [211]. Many authors focused on the progress of composite materials fabrication-integrating CNTs to enhance its applications in biomedical field [212-216].

Nanodiamonds (4-10 $\mathrm{nm})$ are typically different from other nanostructures as they are $\mathrm{sp}^{3}$ hybridized [203]. They show admirable protein binding ability and can be used as a carrier for some biomolecules such as BMP-2 [217]. The carbon nanotube/gold hybrids are employed commonly for the delivery of the anticancer drug doxorubicin hydrochloride into A549 lung cancer cell line [218].

Nanoscaffolds can be produced by electrospinning poly( $\varepsilon$-caprolactone) (PCL) and different types of carbon nanomaterials such as carbon nanotubes, graphene, and fullerene [219]. Mesoporous silica $\left(\mathrm{mSiO}_{2}\right)$ decorated carbon nanotubes (CNTs) hybrid composite were used for the simultaneous applications of gentamicin and protein cytochrome C delivery and imaging [220]. Single-walled carbon nano-horns encapsulated with positively charged lipids complex were used for targeted drug and protein delivery [221].
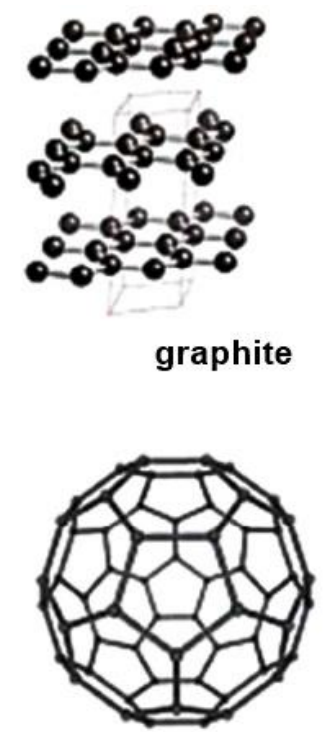

fullerene

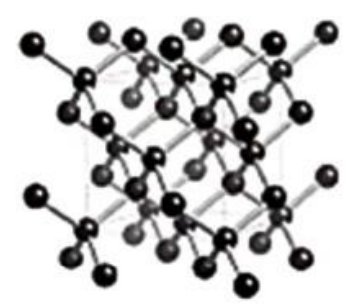

diamond

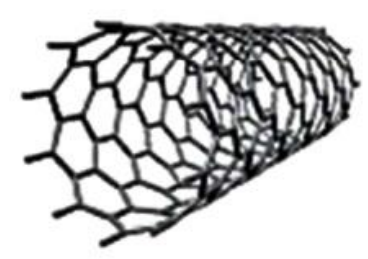

nanotube

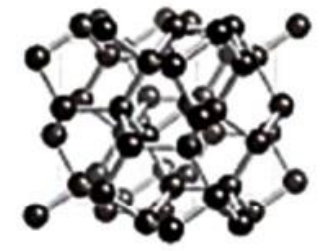

BCB

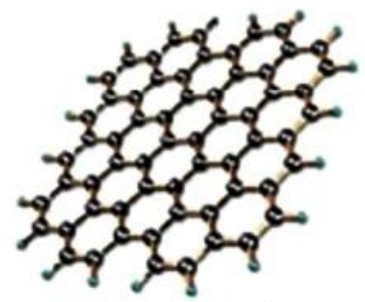

graphene

Figure 11. Structure of various allotropes of carbon (adapted with permission from Royal Society of Chemistry [205]). In the figure, "BCB" stands for "benzocyclobutene".

\subsubsection{Summary and Statistical Analysis of the Survey on Organic Nanobiomaterials}

The survey on organic nanobiomaterials presented in Section 2.1 regarded some 200 articles. Polymeric nanomaterials, carbon nanostructures, and nanocomposite materials are the most widely investigated subject (60.8\% of the studies), followed by dendrimers (21.1\%) and lipids/liposomes (18.1\%). While dendrimers and lipid/liposomes are mainly utilized as nanocarriers, the other nanomaterials cover a much broader spectrum of applications. The development of new nanomaterials (especially carbon nanomaterials or materials including natural bone constituents such as, for example, collagen) that can improve tissue regeneration, cell growth, and drug/protein delivery currently represents the main research area in the field of organic nanobiomaterials with a strong tendency to design hybrid materials and improve fabrication techniques of the resulting nanocomposite materials/scaffolds/structures. Such a trend has become very clear in the last 5-6 years. However, much work remains to be done 
in order to fully understand interactions between different phases of nanocomposite materials and cell/tissues to be repaired/treated. Another important issue strictly related to the above mentioned one is how to "optimize" the composition of the nanocomposite for the specific purposes on which the material itself is designed.

\subsection{Inorganic Nanobiomaterials}

Inorganic biomaterials are those lacking carbon element and they are widely employed for in vivo and in vitro biomedical research [222]. These crystalline or glass structured nanomaterials are used to replace or restore a body tissue [36]. The main applications of inorganic biomaterials, including bioceramics and bioglasses, are for orthopedics and dentistry. Modifications in composition and fabrication techniques may produce a range of biocompatible materials such as bioceramics [223]. Natural bone also includes inorganic materials like calcium $(\mathrm{Ca})$ and phosphorus $(\mathrm{P})$ in the form of hydroxyapatite (HA) crystals, as well as carbonate $\left(\mathrm{CO}_{3}{ }^{2-}\right)$, potassium $(\mathrm{K})$, fluoride $(\mathrm{F})$, chlorine $(\mathrm{Cl})$, sodium $(\mathrm{Na})$, magnesium $(\mathrm{Mg})$, and some trace elements including copper $(\mathrm{Cu})$, zinc $(\mathrm{Zn})$, strontium (Sr), iron (Fe), and silicon (Si) [224]. Therefore, it is very logical to investigate on nanomaterials based on these inorganic constituents.

Table 2 presents a general classification of inorganic nanobiomaterials and summarizes representative applications of each material in tissue engineering. The following subsections present a general description of each nanomaterial type listed in Table 2 and a detailed literature survey on the corresponding developments for tissue engineering.

Table 2. Types of inorganic nanomaterials with their applications.

\begin{tabular}{|c|c|c|c|}
\hline Types of Nanomaterials & Size (nm) & Applications & References \\
\hline Nano Silica & $10-100$ & $\begin{array}{c}\text { Composite-based scaffold } \\
\text { Bio-imaging } \\
\text { Drug delivery } \\
\text { Enhanced osteogenic differentiation }\end{array}$ & [225-227] \\
\hline $\begin{array}{l}\text { Gold nanostructured } \\
\text { materials }\end{array}$ & $5-50$ & $\begin{array}{c}\text { Bioinorganic hybrid nanostructures } \\
\text { Thin film scaffold } \\
\text { Bio-imaging }\end{array}$ & [228-230] \\
\hline $\begin{array}{l}\text { Magnetic nanomaterials } \\
\text { and nanoparticles }\end{array}$ & 10 & $\begin{array}{l}\text { Drug and gene delivery } \\
\text { Improved cell adhesion } \\
\text { Cell tracking }\end{array}$ & {$[21,231,232]$} \\
\hline Bioactive Glasses & $20-500$ & $\begin{array}{l}\text { Improved scaffolds performance } \\
\text { Drug and gene delivery }\end{array}$ & {$[233,234]$} \\
\hline Silver nanoparticles & $1-100$ & $\begin{array}{l}\text { Tissue repair and regeneration } \\
\text { Antibacterial action }\end{array}$ & [235-237] \\
\hline Nanostructured Titanium & $<300$ & $\begin{array}{l}\text { Nano tubular anodized titanium } \\
\text { Improved mechanical properties } \\
\text { Enhanced chondrocyte adhesion } \\
\text { Support osteoblast adhesion and proliferation } \\
\text { Orthopedic coating }\end{array}$ & [238-243] \\
\hline Hydroxyapatite & $\begin{array}{c}20-80 \\
\sim 200-500\end{array}$ & $\begin{array}{l}\text { Enhanced osteoblast functioning } \\
\text { Increase bone apatite formation }\end{array}$ & {$[244,245]$} \\
\hline Zirconia nanoparticles & $<100$ & $\begin{array}{l}\text { Enhanced osteointegration } \\
\text { Antibacterial implants formation }\end{array}$ & {$[246,247]$} \\
\hline Alumina nanoparticles & $<80$ & $\begin{array}{c}\text { Enhanced bone cells adhesion and } \\
\text { proliferation } \\
\text { Calcium phase deposition }\end{array}$ & {$[245,248]$} \\
\hline Copper nanoparticles & $<100$ & Antimicrobial implant fabrication & [25] \\
\hline
\end{tabular}

\subsubsection{Nano Silica}

A huge amount of investigations on biomedical applications of silica nanostructures have been carried out in the past decade [249]. The ability to synthesize uniform, porous and dispersible 
nanoparticles, together with the fact that particles' size and shape can be easily controlled [226], certainly favored the variety of applications of silica in tissue engineering [250]. Furthermore, as silica is biocompatible and chemically stable [251,252], it has been used also for biomedical imaging and medication administration [225], either itself or as a coating of other compounds [251].

Mesoporous silica nanoparticles (MSNPs) have been used as a drug delivery vehicle [253] and to improve mechanical properties of biological materials. It was noted their use as well as for sustained and prolonged release or administration of intracellular genes in bone tissue engineering [226]. MSNPs work as efficient biocompatible nanocarriers due to (i) high visibility, (ii) dispersibility, (iii) binding capability to a target tissue, (iv) ability to load and deliver large concentrations of cargos, and (v) triggered or controlled release of cargos [250]. The functioning of MSNPs can be tailored by modifying the silanol group present within the pore interiors and on the outer surface. These positive chemical moieties are adsorbed by negatively charged $\mathrm{SiO}^{-}$groups at neutral $\mathrm{pH}$, through electrostatic interactions (Figure 12).

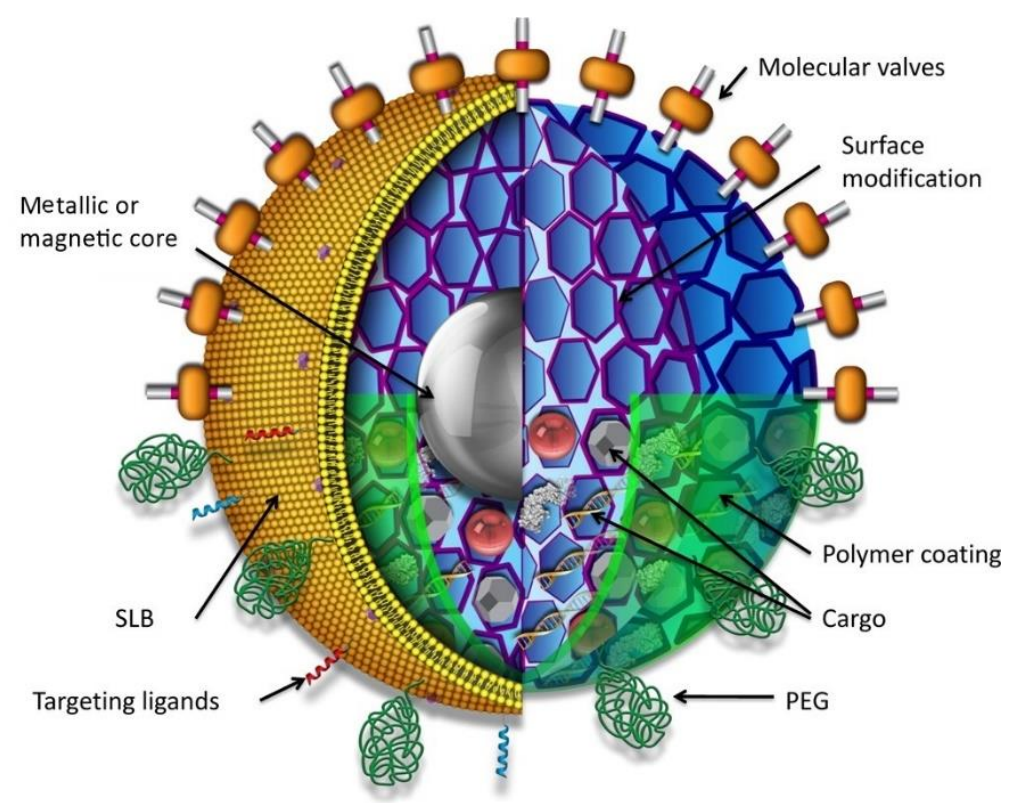

Figure 12. Schematic of a multifunctional mesoporous silica nanoparticle showing possible core/shell design, surface modifications, and multiple types of cargos. (Adapted with permission from (C) 2013 American Chemical Society [250]).

Anitha et al. [254] reported a composite matrix containing crystalline rod-shaped core with uniform amorphous silica sheath (Si-n HA), which showed good biocompatibility, osteogenic differentiation, vascularization, and bone regeneration potential. Silicate containing hydroxyapatite stimulates cell viability of human mesenchymal stem cells for extended proliferation [255]. Zhou et al. [256] synthesized PLGA-SBA15 composite membranes with different silica contents by electrospinning method; these membranes showed better osteogenic initiation then the pure PLGA membranes. Ding et al. [257] successfully fabricated levofloxacin (LFX)-loaded polyhydroxybutyrate/ poly( $\varepsilon$-caprolactone) (PHB/PCL) and PHB/PCL/sol-gel-derived silica (SGS) scaffolds, which support the growth of MG-63 osteoblasts. A microfluidic device was used to generate photo-cross-linkable gelatin microgels (GelMA), coupled with providing a protective silica hydrogel layer for applications in injectable tissue constructs [258]. Dexamethasone (DEX)-loaded aminated mesoporous silica nanoparticles (MSNs-NH2) were prepared via electrophoretic deposition (EPD) and successfully incorporated within poly(l-lactic acid)/poly( $\varepsilon$-caprolactone) (PLLA/PCL) matrix to fabricate composite nanofibrous scaffolds for bone tissue engineering applications [259]. 


\subsubsection{Nano Bioglass}

Bioglasses (BG) have been intensively investigated as biomaterials since their discovery in 1969 and first developments in the 1970s made by L. Hench [260]. Compared to common glass, bioglass contains less silica and higher amounts of calcium and phosphorous. As a biomaterial for tissue engineering, bioglass is applied independently or in combination with a number of polymers [261] (Figure 13). BG can arouse fibroblasts with higher bioactivity by accelerating bioactive growth factors and proteins as compared to untreated fibroblasts [262].

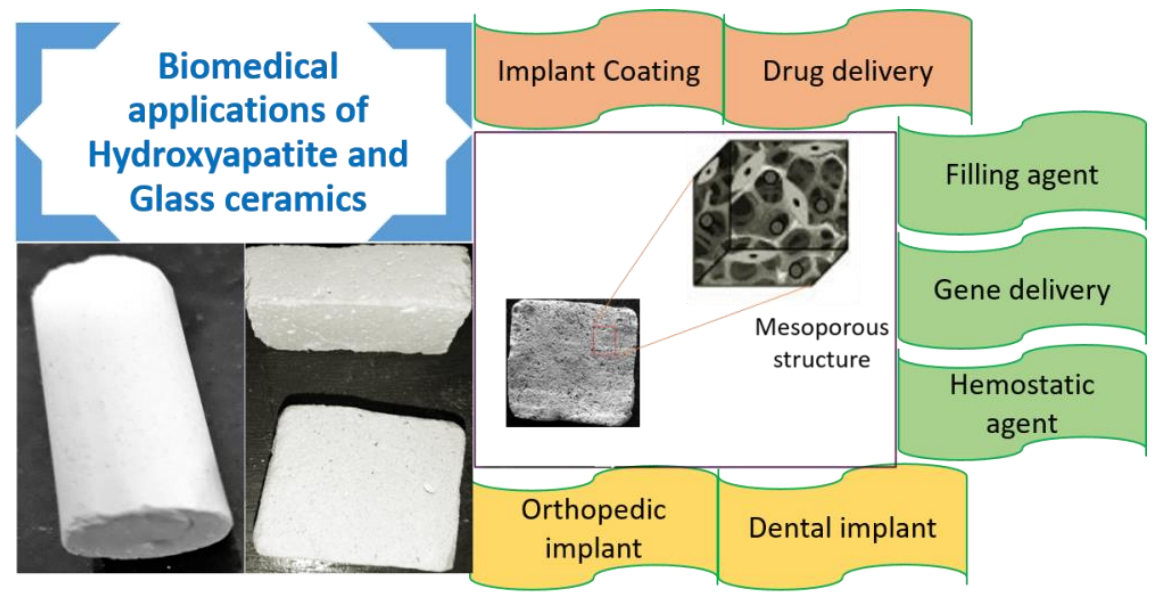

Figure 13. Biomedical applications of hydroxyapatite and glass ceramics.

BG degrade slowly when implanted into the targeted patient's site and release ions, which favors the biosynthesis of hydroxyapatite [263]. The silica-rich surface of bioglass promotes the exchange of $\mathrm{Ca}^{2+}$ and $\mathrm{PO}_{4}{ }^{3-}$ with physiological fluid, which leads to the generation of a Ca-P layer [264,265]. This biodegradation may be enhanced by the presence of a $\mathrm{SiO}_{2}$ network, which forms non-bridging silicon-oxygen bonds [266]; the low connectivity of the $\mathrm{SiO}_{2}$ network enhances dissolution of bioglass while the presence of $\mathrm{Na}$ and $\mathrm{Ca}$ forms $\mathrm{Si}-\mathrm{O}-\mathrm{Si}$ bonds and reduces dissolution rate. Mesoporous BG can be fabricated using the sol-gel method, which can be a good carrier for targeted drug delivery [267]. The sol-gel method was also used by Kumar et al. [268] to develop bioglass nanoparticles with a higher content of silica, which are suited for bone tissue applications.

Bioglass nanoparticles show high biocompatibility and surface area, which can enhance in vitro osteoconductivity as compared to layer and microsized particles of bioglass [269]. The size of the particles can be modified by changing the synthesis parameters and techniques. However, because of its brittleness, the glass alone cannot be used to heal large bone defects [270]. In order to solve this issue, Bioglass 4555 was used with poly(D,L-lactide) (PDLLA), a biodegradable polymer, to form a composite scaffold with enhanced biomechanical characteristics [271]. The early failure of a bioglass composite at the interface occurs because of nonuniform mechanical strength, phase separation, nonhomogeneous mixture, and different degradation properties of two compounds. A hybrid composite of poly(methyl methacrylate) (PMMA) and bioactive glass was manufactured via the sol-gel method (Figure 14) to enhance physicochemical and mechanical properties [272].

An elastin-like polypeptidic and bioglass (ELP/BG) hydrogel was also fabricated that is mechanically robust, injectable, and self-healable. This ELP/BG biocomposite can be useful for drug delivery and tissue engineering purposes [273]. A 3D construct of type-I collagen and 45S5 Bioglass meets the basic requirements of a scaffold including biocompatibility, osteoconductivity, osteoinductivity, and biodegradability [274]. Bioglass nanoparticles were also used with bacterially derived poly(3-hydroxybutyrate) to fabricate bioactive composite film using a fermentation technique [275]. Different glass modifiers $\left(\mathrm{Mg}^{2+}, \mathrm{Ca}^{2+}\right.$, and $\left.\mathrm{Sr}^{2+}\right)$ were used to prepare borosilicate bioactive glasses through a melt-quenching technique which showed good antibacterial properties [276]. 
Poly(propylene fumarate) (PPF) was used to functionalize bioglass particles that enhance the bioactivity and cell adhesion, proliferation, and bone regeneration [277].

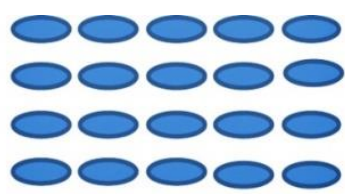

MMA monomers

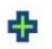

MPMA
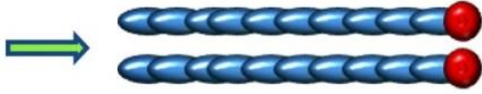

PMMA-co-MPMA

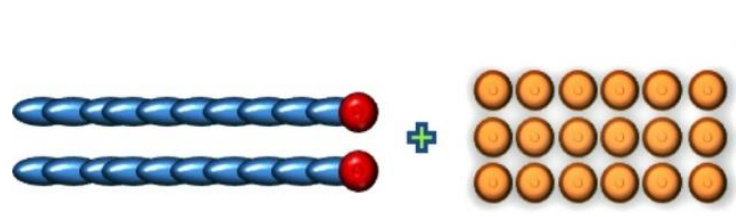

Hydrolysed silica (silica sol)

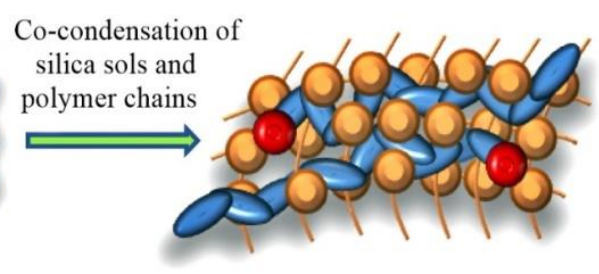

3D structure of PMMA-bioglass hybrid

Figure 14. Schematic procedure for the fabrication of a PMMA-bioglass class II hybrid (Adapted with permission from (C) 2013 American Chemical Society [272]).

\subsubsection{Nano Hydroxyapatite}

Hydroxyapatite $\left(\mathrm{Ca}_{10}\left(\mathrm{PO}_{4}\right)_{6}(\mathrm{OH})_{2}\right)$ is a significant natural mineral constituent of bones $(70 \%$ wt.) and teeth $(96 \%$ wt.) $[278,279]$. Synthetic HA is a biocompatible ceramic material, used for biomedical applications (Figure 13) because it may replicate the behavior of mineral part of the bone $[280,281]$. It shows outstanding biocompatibility with bones, teeth, skin, and muscles, both in vitro and in vivo $[282,283]$. The stoichiometric molar ratio $\mathrm{Ca} / \mathrm{P}$ in synthetic $\mathrm{HA}$ of 1.67 is not the actual ratio in the hydroxyapatite of normal bones, because of the presence of other elements such as $\mathrm{C}, \mathrm{N}, \mathrm{Fe}$, $\mathrm{Mg}$, and $\mathrm{Na}$ [284]. Hydroxyapatite (HA) can be easily synthesized by using different methods such as hydrothermal, sol-gel, and co-precipitation methods [285]. The comparison of mineral compositions of hydroxyapatite, bone and teeth is shown in Table $3[286,287]$.

Table 3. Mineral composition of hydroxyapatite, bone, and teeth.

\begin{tabular}{ccccccc}
\hline Types & $\mathbf{C a}$ & $\mathbf{P}$ & $\mathbf{C a} / \mathbf{P}$ & Total Inorganic (\%) & Total Organic (\%) & Water (\%) \\
\hline HA & 39.6 & 18.5 & 1.67 & 100 & - & - \\
\hline Dentine & 35.1 & 16.9 & 1.61 & 70 & 20 & 10 \\
\hline Bone & 34.8 & 15.2 & 1.71 & 65 & 25 & 10 \\
\hline Enamel & 36.5 & 17.1 & 1.63 & 97 & 1.5 & 1.5 \\
\hline
\end{tabular}

HA shows such excellent biocompatibility, bio-inertia and bioactivity without toxicity, immunogenicity [288,289]. It has a good ability to make bonds with bone directly and it is primarily used in therapeutic applications such as implants and fillers for bones and teeth in different forms [290]. To overcome the low mechanical strength of hydroxyapatite scaffolds, a large number of natural and synthetic polymers were combined with HA such as collagen, polyethylene, polylactic acid, alginates, poly(methyl methacrylate), and polycaprolactone [136].

Woodard et al. [291] compared the activity of nano- and microsized ceramic materials in the body. Their studies demonstrated a substantial increase in osteoblast adhesion and protein adsorption in nanomaterials. The major components of the inorganic nanostructure can have a higher biological activity than micro-components [245]. Polydopamine (pDA)-templated hydroxyapatite (tHA) was introduced into polycaprolactone (PCL) matrix to make bioactive tHA/PCL composite based fibrous 
scaffold; in vitro and in vivo investigations (Figure 15) showed a favorable cytocompatibility at a given concentration of tHA (0-10\% wt.) [292].

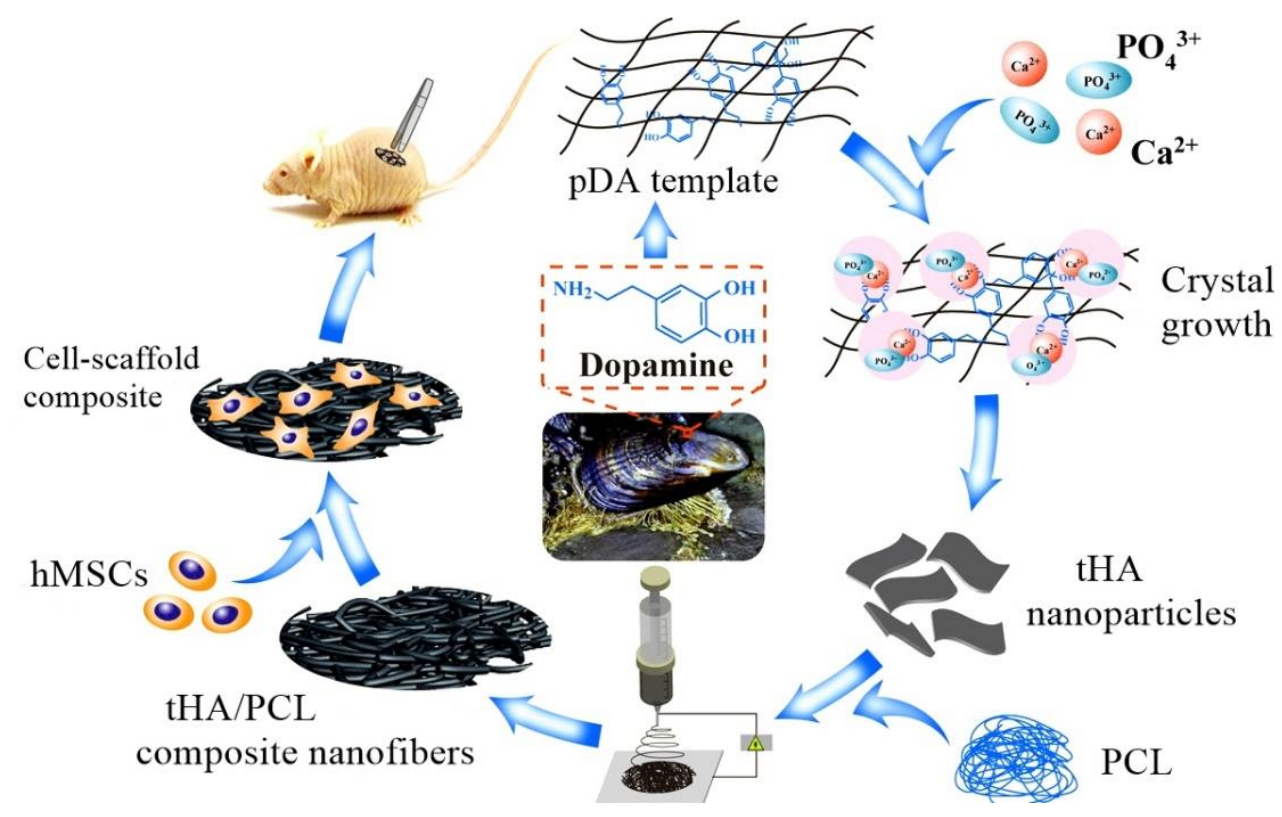

Figure 15. Schematic illustration of preparation and evaluation of tHA/PCL composite nanofibers. (Adapted with permission from (C) 2016 American Chemical Society [292].)

A new type of scaffold with bamboo fiber (5\%) incorporated nano-hydroxyapatite/poly(lactic -co-glycolic) (30\%) was fabricated via freeze-drying; bamboo fibers improved biomechanical properties of n-HA/PLGA composite scaffolds thus developing a superior potential for bone tissue engineering [293]. Sol-gel synthesized hydroxyapatite- $\mathrm{TiO}_{2}$-based nanocomposites synthesized in supercritical $\mathrm{CO}_{2}$ have better Young's and flexural moduli than PCL/HAp composites [294]. A set of techniques including molding/particle leaching and plasma-treated surface deposition were used to fabricate bilayered PLGA/PLGA-HAp composite scaffold [295]; the in vivo rat model experiment proved that the new composite is suitable for osteochondral tissue engineering applications. Electrospinning mediated

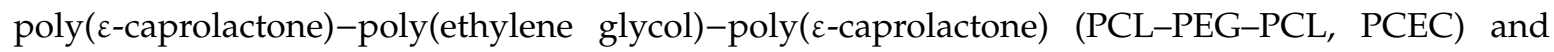
nano-hydroxyapatite (n-HA) composite scaffolds showed good biocompatibility and nontoxicity [296]. Hydroxyapatite/ $\mathrm{Na}(\mathrm{Y} / \mathrm{Gd}) \mathrm{F}_{4}: \mathrm{Yb}^{3+}, \mathrm{Er}^{3+}$ composite fibers [297], and gadolinium-doped mesoporous strontium hydroxyapatite nanorods [298] were successfully used in drug storage/release applications.

\subsubsection{Silver Nanoparticles}

Silver proved its bactericidal activities against many bacteria since 1000 B.C. Now silver is used as an antiseptic, antibacterial, and antitumor agent [299]. Because of their strong antibacterial activity against both Gram-positive and Gram-negative bacterial strains, silver nanoparticles were widely used for fabricating antibacterial nanocomposite-based scaffolds and coated implants [235,237]. Furthermore, silver may be combined with different materials such as CNT [300], chitosan, HA [301], and manganite [302] to get a specific function. Ag-doped or coated implants allow reducing the number of bacterial infections without interfering with bone cell growth in the body (Figure 16 [303]). The antimicrobial activity of Ag has been reported against Escherichia coli [304], Candida albicans [11], Vibrio cholera [305], and Staphylococcus aureus [306]. 


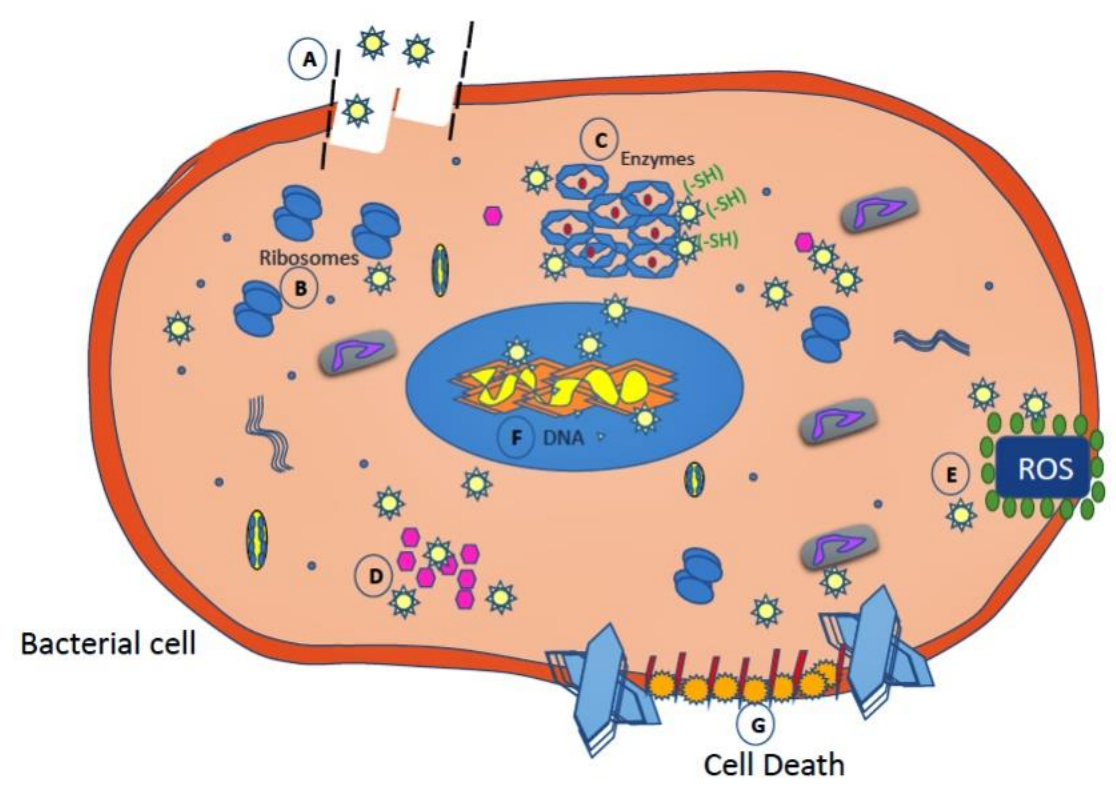

Figure 16. Schematic diagram representing mechanisms of action of Ag nanoparticles for antibacterial action (adapted with permission from Elsevier (C) 2018 [303]). (A) AgNP diffusion and uptake into the bacterial cell. (B) Destabilization of ribosomes. (C) Enzyme interaction. (D) Interruption of electron transfer chain. (E) Reactive oxygen species (ROS). (F) DNA damage. (G) Cell death.

In addition to antibacterial activity, Ag nanoparticles promote wound healing, reduce scar formation, and reduce inflammation [307]. Silver nanoparticles have many applications as antimicrobial agents when combined with different biological substances [308]. A micrometer-sized surface-enhanced Raman spectroscopy (SERS) substrate, core-shell microparticles composed of solid carbonate core coated with silver nanoparticles, and polyhedral multishell fullerene-like structure were developed for biomedical applications [309]. Soft poly(vinyl alcohol) (PVA) hydrogel films containing silver particles prepared on solid biodegradable poly(l-lactic acid) (PLLA) exhibit both antibacterial and reduced cell adhesion properties [310]. Biocompatible maleimide-coated silver nanoparticles (Ag NPs) can be used as co-cross-linkers for the preparation of a nanocomposite gelatin-based hydrogel. Covalently bound Ag nanoparticles support swelling and drug release properties of composite hydrogel without producing toxicity [311]. In situ fabricated Ag NPs (4-19 nm) and immobilized on titanium by using a plasma immersion ion implantation process motivated osteoblast differentiation in rat bone marrow stem cells (BMSCs) [312]. Patrascu et al. [313] fabricated collagen/hydroxyapatite-silver nanoparticles (COLL/HA-Ag)-based antiseptic composite for biomedical applications.

\subsubsection{Gold Nanoparticles}

Gold nanoparticles (GNPs) are defined as a colloid of nanometer-sized particles with better properties than bulk gold. They are produced in different shapes such as spheres [314], rods [315], star-like [316], and cages [317]. GNPs possess unique characteristics, such as easy-to-control, nanoscale size, easy preparation, high surface area, easy functionalization, and excellent biocompatibility, that make them highly suited for many tissue engineering and more in general for biotechnology applications [318,319]. GNPs are definitely superior over other types of nanoparticles in terms of low toxicity and colloidal stability. Furthermore, they present an outstanding physicochemical behavior, which is related to local plasmon resonance phenomena.

Gold nanoparticles were utilized for biosensing [320], bioimaging [321-323], cancer therapy [324], gene delivery to enhance osteogenic differentiation [325], and photo-thermal therapy [229,314,316,323]. Gold nanoparticles were also combined with other materials such as silica (to produce core and shell nanoparticles) $[318,323]$ as well as natural polymers (to improve mechanical properties) and synthetic polymers (to enhance biocompatibility) [318]. 
Due to their excellent biocompatibility and chemical inertness, gold nanoparticles became the ideal choice for the preparation of scaffolds in many cases [318]. The mission of GNPs in tissue engineering and regenerative medicine is to act as a multimodal tool in order to improve scaffold properties, cell differentiation and intracellular growth factor delivery (Figure 17), while monitoring cellular events in real-time [326].

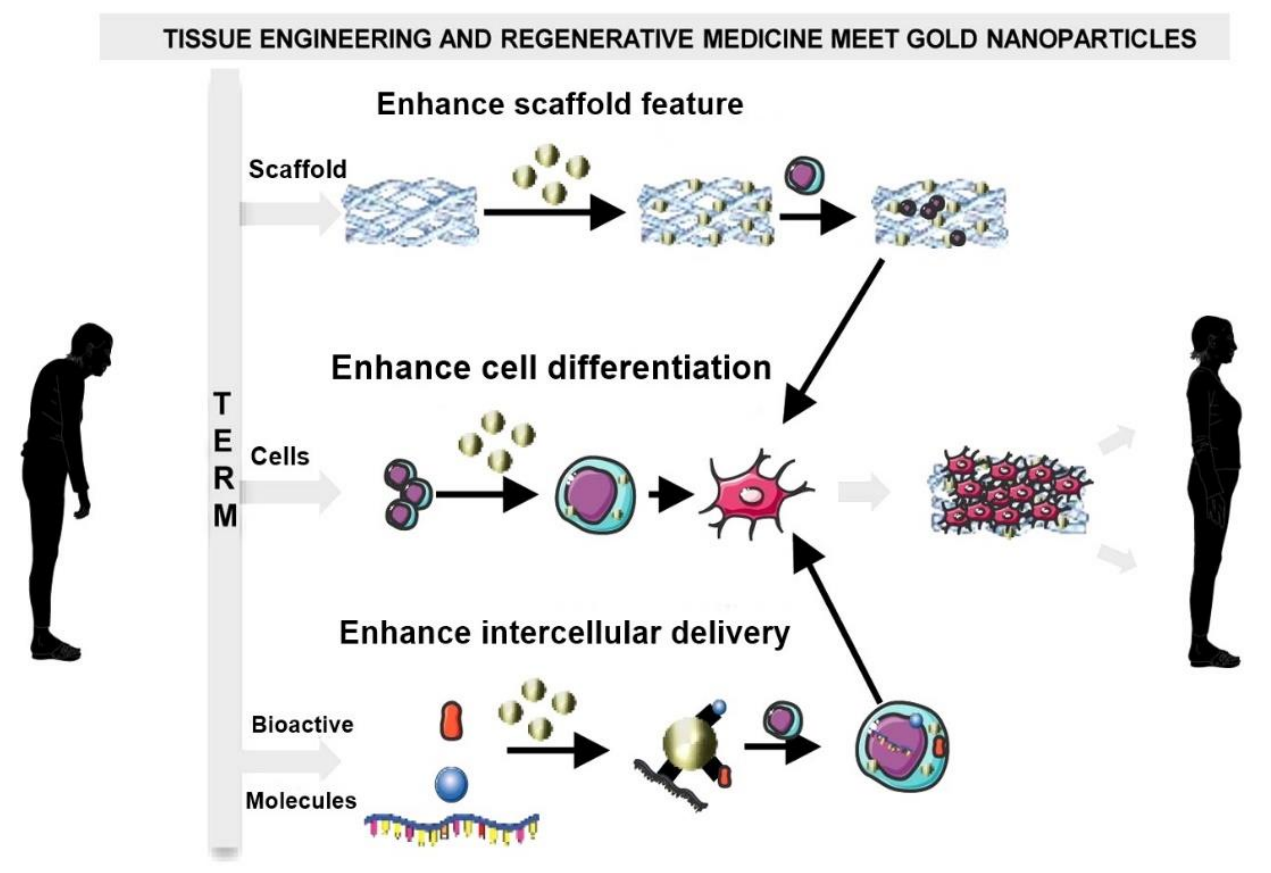

Figure 17. Scheme representing the importance of introducing GNPs in tissue engineering and the regenerative medicine (TERM) realm [326]. (Adapted with permission from Elsevier (C) 2017).

\subsubsection{Titanium Dioxide}

Titanium is widely used in many surgical applications (e.g., prostheses and implants) because of its excellent biocompatibility, good mechanical properties, and lower mass density than steel [327]. The low density and high specific strength of titanium results in lightweight implants with good mechanical properties $[238,239]$. Furthermore, the smooth surface of Ti mesh prevents bacterial contamination instead of adsorbate materials. Therefore, titanium mesh provides an excellent solution to guide bone regeneration [243].

Nanostructured $\mathrm{TiO}_{2}$ materials of various morphologies such as nanoparticles, nanorods, nanowires, nanotubes, and other hierarchical nanostructures can be produced using different techniques such as, for example, microwaves [328,329], hydrothermal/solvothermal processes [330,331], sol-gel [332,333], anode oxidation [334,335], chemical vapor deposition [336,337], sonochemical processes [338,339], and green synthesis [340-342].

As can be seen from Figure 18, nanostructured $\mathrm{TiO}_{2}$ is a multifunctional material for a wide range of applications in engineering and biomedical areas. Interestingly, $\mathrm{TiO}_{2}$ nanoparticles represent a miniature of electrochemical cells capable of light-induced redox chemistry. This quality can be used for manipulating biomolecules and cell metabolic processes. $\mathrm{TiO}_{2}$ nanoparticles prove to have a higher affinity for binding proteins and other cellular components when used within cellular environment $[343,344]$. $\mathrm{TiO}_{2}$ nanoparticles can also be used to enhance photodynamic therapy (PDT) and sonodynamic therapy (SDT) [345]. 


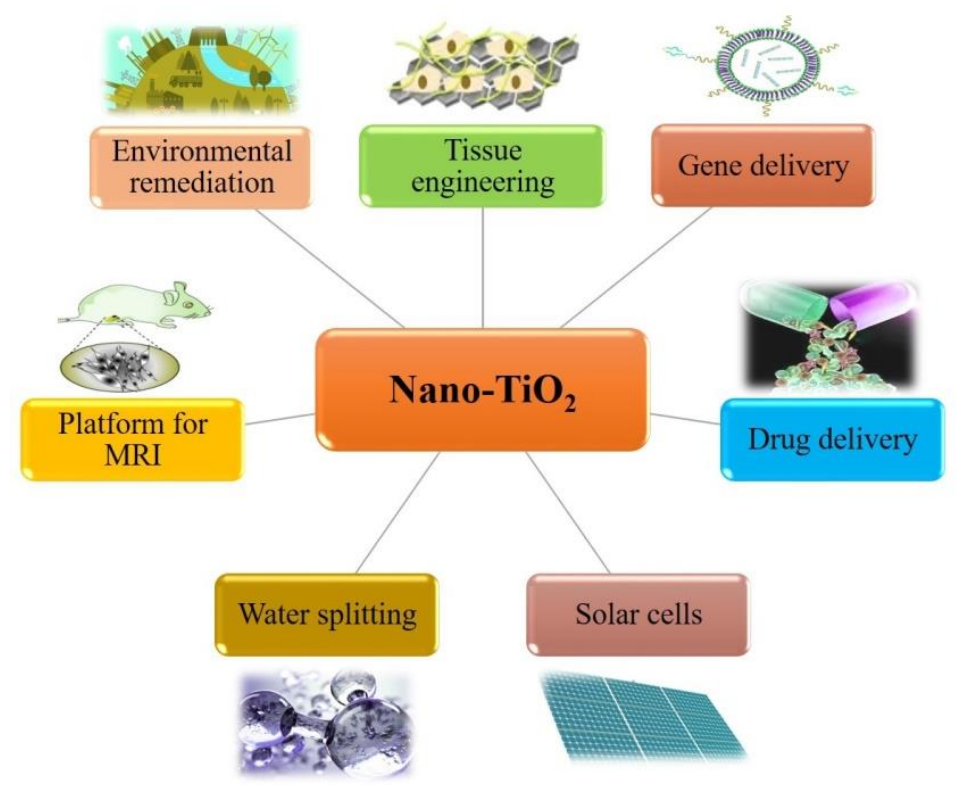

Figure 18. Schematic representation of the many fields of applications of nanostructured $\mathrm{TiO}_{2}$.

Titanium nanotubes (TNTs) possess excellent biocompatibility and drug-releasing performance. Furthermore, they can be generated on the surface of the existing medical implants [346,347]. The physical adsorption of the drugs promotes the anti-inflammatory properties of the TNTs, and with improved osteoblast adhesion, the drug-eluting technique is extended [348].

$\mathrm{TiO}_{2}$ based scaffolds are biocompatible, have good osteoconductive performance and antibacterial properties [349], and show high porosity, excellent interconnectivity, and sufficient mechanical strength [350,351]. Nanostructured $\mathrm{TiO}_{2}$ can be combined with several polymers including polylactic acid (PLA) [352]; poly(ether-ether ketone) (PEEK) [353]; poly(lactic-co-glycolic acid) (PLGA) [354]; and inorganic materials such as $\mathrm{SiO}_{2}$ [355], $\mathrm{Al}_{2} \mathrm{O}_{3}$ [356], bioglass [357], hydroxyapatite [358], graphene [359], and calcium phosphate [360].

Nano- $\mathrm{TiO}_{2}$ surface coated implants can limit autoimmune reactions between the underlying bone tissue surfaces and the implant [361]. However, material deterioration or generation of chronic inflammation in the implanted tissues may reduce success rate [361,362]. Various $\mathrm{TiO}_{2}$ nanostructures were used for loading and eluting cefuroxime as an antibiotic on orthopedic implants [363].

\subsubsection{Zirconia}

Zirconia was first recognized by M.H. Klaproth in 1789 and used as a pigment for ceramics for a long time [364]. Since the 1970s, zirconia received massive consideration as a biomedical material in association to its chemical and biological inertness [365]. Consequently, zirconia was also used to overcome the brittleness of alumina and the consequent failure of implants [366], and as a material for the repair and replacement of bones due to its unique biomechanical properties [367].

Investigations on zirconia biomaterials began in the 1960s. Classical orthopedics studied for many years have used zirconia in the area of hip replacement [368,369]. Zirconium oxide (zirconia) possesses improved mechanical properties and has become one of the most popular ceramic materials in the field of healthcare due to its high biocompatibility and low toxicity [364,370].

Zirconia is one of the most useful structured ceramics because it provides high resistance to bending and fracture. However, zirconium oxide with a low fracture toughness due to the presence of alumina abrasive grains [371] also was introduced as an alternative to having excellent wear resistance due to the unwanted release of orthopedic alumina. Porous zirconia stents can be manufactured by cutting CAD/CAM blocks in the desired shape, and zirconia stents assembled with HA significantly increase the volume of new bone formation in vivo [372]. 
While it might be concluded that zirconia has one of the best combinations of mechanical strength, fracture resistance, biocompatibility, and biological activity, its performance can be further enhanced via a proper modification of material's surface or by combining the material with some other bioactive ceramics and glass [367]. In addition, as a result of the introduction of Zr into the Ca-Si system, no toxicity was observed. Previous studies confirmed that the optimum content of zirconium and strontium increases the surface energy of the magnesium alloy and enhances the ability to stimulate bone formation around the implant $[373,374]$. Hydroxyapatite and fluorapatite slurry coated zirconia scaffolds induce osteoconductivity and enhance bonding strength up to $33 \mathrm{MPa}$ [375]. The dispersion of zirconia with alumina lead to produce $\mathrm{ZrO}_{2}$-toughened alumina $\left(\mathrm{Al}_{2} \mathrm{O}_{3}\right)$, known as zirconia-toughened alumina (ZTA) [376].

Zirconia $\left(\mathrm{ZrO}_{2}\right) / \beta$-tricalcium phosphate $(\beta-\mathrm{TCP})$ composite has shown excellent mechanical properties and supports osteoblast regeneration [377]. Silk fibroin-chitosan-zirconia (SF/CS/nano $\mathrm{ZrO}_{2}$ ) and chitin-chitosan/nano $\mathrm{ZrO}_{2}$ composites provide a suitable environment for cell infiltration and colonization [378,379]. Different temperature based hydroxyapatite-zirconium composites such as $873 \mathrm{~K}$ (HZ600), $923 \mathrm{~K}$ (HZ650), and $973 \mathrm{~K}$ (HZ700) demonstrated that osteoblast growth and mineralization were not influenced by any composite [380]. A new biphasic calcium phosphate (BCP) scaffold reinforced with zirconia $\left(\mathrm{ZrO}_{2}\right)$ was fabricated through the fused deposition modeling (FDM) technique. The $90 \% \mathrm{BCP}$ and $10 \% \mathrm{ZrO}_{2}$ scaffold thus created had significantly better mechanical properties than 100\% BCP and $0 \% \mathrm{ZrO}_{2}$ scaffold [381].

$\mathrm{ZrO}_{2}$ nanoparticle (NP)-doped CTS-PVA-HAP composites (ZrCPH I-III) showed improvement in the tensile strength of ZrCPH I-III with respect to the CTS-PVA-HAP scaffold [382]. Sol-gel cum solvothermal derived mesoporous titanium zirconium (TiZr) oxide nanospheres were used for ibuprofen, dexamethasone, and erythromycin drugs loading and in vitro release studies [383]. The excellent biocompatibility of Zr makes it a good material for metal-organic frameworks (MOFs). Surface functionalization of Zr-fumarate MOF (Figure 19) was used for dichloroacetate (DCA) drug loading, which is more efficient at transporting the drug mimic calcein into HeLa cells [384].

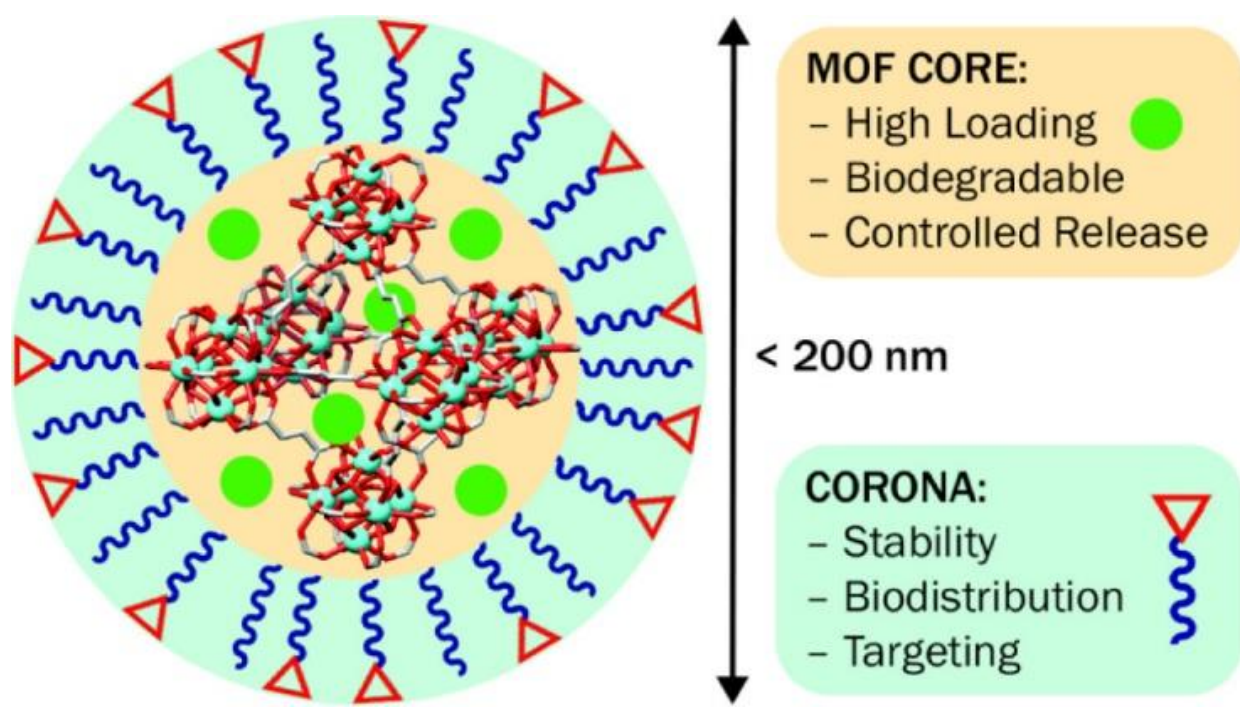

Figure 19. Schematic showing the Zr-fumarate structure with preferred properties of a metal-organic framework (MOF)-based drug delivery device (adapted with permission from (C) 2018 American Chemical Society [384]).

\subsubsection{Alumina}

Since 1975, the bio-inertness of alumina has been confirmed. Alumina has very high hardness and resistance to abrasion on the Moh scale next to diamond [385]. In addition, the crystalline nature of alumina makes it insoluble at room temperature in regular chemical reagents [386]. Alumina has been 
used in many fabrications of artificial implants since it was inserted into an artificial femur head in the 1970s [387]. Pure and densified alumina, $\alpha-\mathrm{Al}_{2} \mathrm{O}_{3}$ (corundum), was the first ceramic material used in the biomedical field for dental restorations, cochlear implants, and load-bearing hip prostheses [388]. As porous alumina does not degrade under in vitro and in vivo environments, it may be used for biosensing [389], good electrical insulation [390], and immune isolation [391].

Properties such as abrasion resistance, power and chemical inertness favor the use of alumina in hard tissue engineering [392]. If the alumina is implanted in bone marrow, no toxic effects are generated in the surrounding tissue [393]. However, the high stiffness of alumina may lead to have a high elastic incompatibility between the biological tissue and the implant [394]. The tensile strength of alumina can be increased by reducing grain size and increasing its density [395]. In view of their good mechanical behavior, alumina implants are characterized by long-time survival predictions [396].

A significant feature in applications involving open and aligned porous structures, such as bone tissue scaffolds, catalysts, and membranes, is the anisotropic nature of porous alumina ceramics [397]. The $\alpha$-alumina is the most stable oxide amongst transient and metastable types [398]. It should be noted that essential physico-chemical properties of alumina surface are significantly affected by the protein adsorption process. For example, the presence of liquid solutions nearby the implanted site can cause accelerated protein adsorption on the alumina's surface [399]. Piconi et al. [394] reported the in vitro biocompatibility of alumina with various cell lines such as fibroblasts and osteoblasts, and immunological cells with various cell environments.

The particle size of alumina may affect biocompatibility, particularly when using nanoparticles because of their high surface/volume ratio [400]. Alumina suspensions (70\% wt.) and wheat flour (20-30\% vol.) were used to synthesize different particle sized porous alumina ceramics [401]. Hydroxyapatite/alumina composite based foam was synthesized via a precipitation method under a variety of $\mathrm{pH}$ values that showed a good concentration of $\mathrm{Ca}^{2+}$ and $\mathrm{PO}_{4}{ }^{3-}$ contents [402]. The chemical modification of porous alumina surface with vitronectin and peptide (i.e., arginine-glycine-aspartic acid cysteine (RGDC)) enhanced bone cell adhesion and production of extracellular matrix [403].

Porous anodic alumina (PAA) can be fabricated on the surface of other materials through anodization process [404,405]. It can be considered a good nanocontainer to load active agents such as drugs or biomolecules [406]. Evaporation induced self-assembly derived mesoporous aluminum oxide was used for the delivery of poor-water soluble compound Telmisartan (anti-blood pressure drug) with $45 \%$ loading efficiency [407]. The drug is not loaded within the pores of the PAA completely, but the surface itself can hold some of this load, which can be quite high; this promotes another phase release $[408,409]$.

Calcium phosphate with $20 \%$ alumina $\left(\mathrm{Ca}_{3}\left(\mathrm{PO}_{4}\right)_{2}-\mathrm{Al}_{2} \mathrm{O}_{3}\right)$ bio-ceramic composite revealed enhanced biocompatibility and mechanical properties [410]. Using alumina nanowires reinforcement in polyhydroxy butyrate-chitosan (PHB-CTS/3\% $\mathrm{Al}_{2} \mathrm{O}_{3}$ ) scaffolds enhanced the mechanical properties of the scaffold. The addition of alumina increased by ten times the tensile strength of PHB-CTS/3\% $\mathrm{Al}_{2} \mathrm{O}_{3}$, which became higher than its counterpart for the original PHB-CTS scaffold [411].

$\mathrm{Al}_{2} \mathrm{O}_{3}$ coating was used for improving the performance of stainless steel $316 \mathrm{~L}$ and Ti-6Al-4V implants [412]. In general, coating materials are used to protect the surface of the implant material and the interface with the biological system at hand [413]. Nanorod-like HA-coated porous $\mathrm{Al}_{2} \mathrm{O}_{3} \mathrm{was}$ fabricated by anodic oxidation that revealed excellent biological activity in vitro [414].

\subsubsection{Copper}

Copper ions stimulate the proliferation of human vein endothelial cells and mesenchymal stem cells (MSCs) but not human dermal fibroblasts [415,416]. Copper nanoparticles can also act as antifungal and antibacterial agents [417]. Copper is commonly used in bone implants for its antimicrobial activity against a wide range of pathogens [418]. As copper is an essential component of the body, it may be more suitable for in vivo applications [25]. 
The importance of copper has been studied extensively because its deficiency can lead to osteoporosis [419]. $\mathrm{Cu}$ also stimulates angiogenesis and collagen deposition, which are key elements in wound healing [420]. The use of copper-based biomaterials is cost-effective compared to other vital materials based on gold and silver [421].

Copper ions were incorporated into biologically active scaffolds for controlled release to improve vascular strengthening and antimicrobial action for prolonged periods [422]. Copper-doped wollastonite $(\mathrm{Cu}-\mathrm{Ws})$ particles $(1184 \mathrm{~nm})$ have shown biocompatibility towards mouse mesenchymal stem cells (mMSC) up to $0.05 \mathrm{mg} / \mathrm{ml}$ concentration [423]. A freeze-dried chitosan/hydroxyapatite/copper-zinc alloy (CS/nHAp/nCu-Zn) composite-based scaffold showed lower degradation and higher protein adsorption without producing toxicity towards rat osteoprogenitor cells [422]. Collagen-copper-doped bioactive glass (CuBG-CS) scaffolds exhibited enhanced mechanical properties (up to 1.9-fold) and osteogenesis (up to 3.6-fold) than chitosan [424].

Copper nanoparticles were investigated also for wound healing applications. $1 \mu \mathrm{M}$ concentration of $80 \mathrm{~nm} \mathrm{CuNPs}$ was found not to be toxic to the cultured fibroblast, endothelial, and keratinocyte cells, and it supported endothelial cell migration and proliferation [425]. CuNPs may alter the structure of proteins and enzymes, affecting their normal functions and causing inactivation of bacterial functions at the injury site [426]. Chen et al. reported the cytotoxic effect of copper NPs towards human histolytic lymphoma (U937) and human cervical cancer cells by inducing apoptosis [427]. CuNPs were used to design a special drug delivery system for chemotherapy. For example, Figure 20 illustrates a mesoporous, upconversion, nanoparticles (mUCNPs)-based controlled-release drug carrier system exhibiting higher upconversion luminescence emission intensity [428].

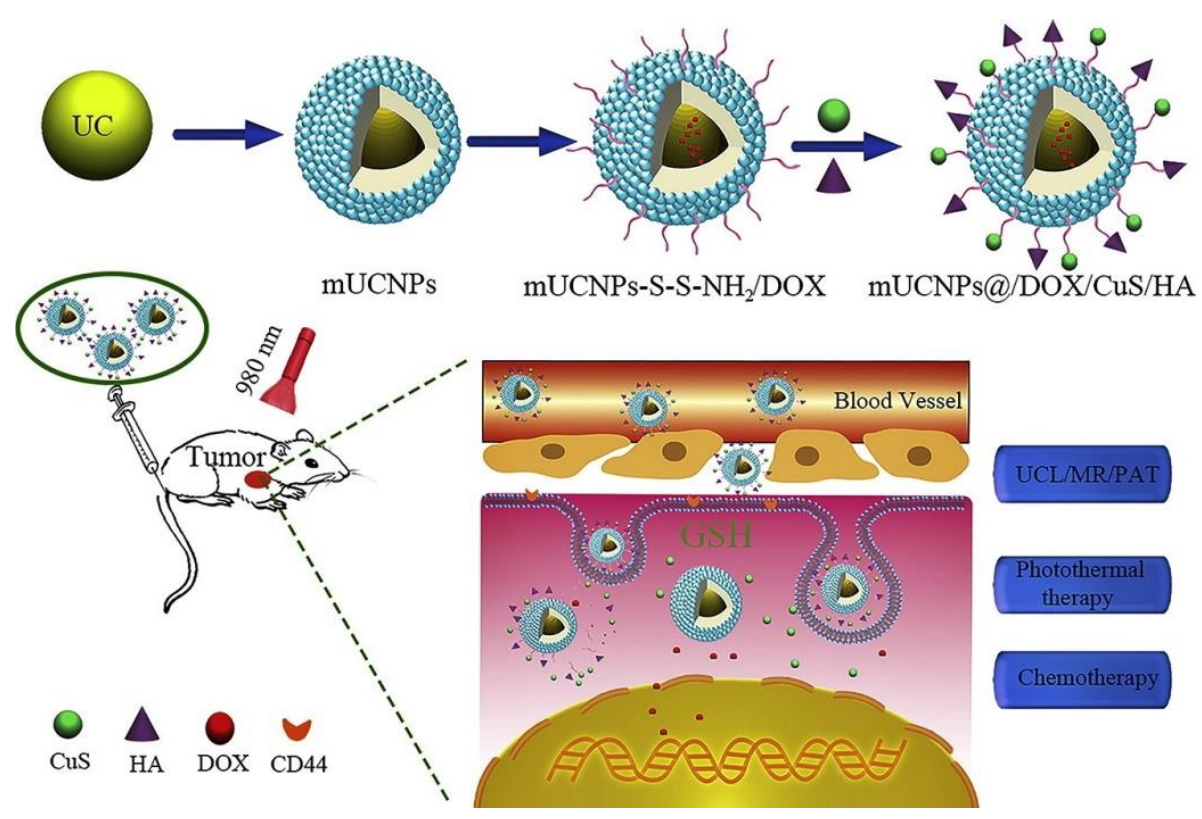

Figure 20. Schematic illustration of the mUCNPs-based redox-stimuli responsive drug delivery system for tumor diagnosis and synergetic chemo-phototherapy (adapted with permission from Elsevier (C) 2017 [428]).

\subsubsection{Magnetic Nanoparticles}

Magnetic elements (i.e., iron, nickel, cobalt, and their oxides) were utilized for the fabrication of nanomaterials for different medical applications [429,430] such as MRI, drug delivery, medical diagnostics, cancer therapy, biosensoring, and magneto-optic devices. Magnetic nanoparticles can be synthesized through different techniques including co-precipitation [431], microemulsion [432], hydrothermal synthesis [433], sol-gel process [434], polyol synthesis [435], flow injection [436], sonolysis/sonochemical methods [437], microwave irradiation [438], electrochemical synthesis [439], 
solvothermal method [440], chemical vapor deposition [441], laser pyrolysis [442], and green synthesis [443] using biomass or biotemplate.

Due to high magnetic flux density, magnetic nanoparticles were used for drug targeting [444] and bio-separation [445], including cell sorting [446]. Sun et al. [447] analyzed metallic, bi-metallic, magnetic cationic liposomes and superparamagnetic iron oxide nanoparticles for imaging and drug delivery. The surface of magnetic nanoparticles also needs to be functionalized to recognize specific targets (Figure 21) [448]. Polyethylene glycol (PEG) is one of the best polymers used for the functionalization of magnetic nanoparticles by surface modification [449]. Interestingly, surface modified magnetic nanoparticles reduce nonspecific interaction with biological molecules.

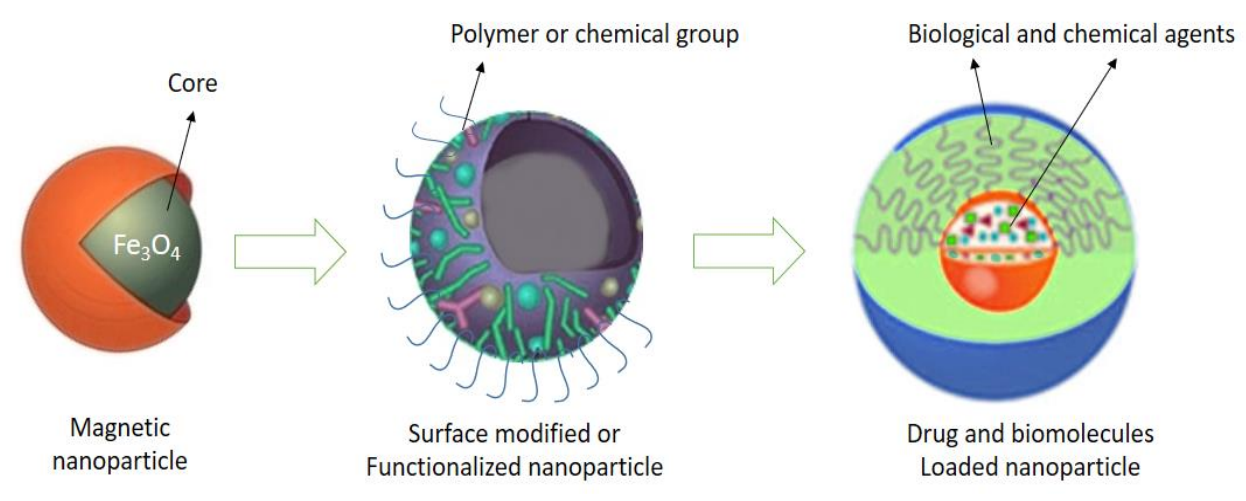

Figure 21. Surface modified magnetic nanoparticle.

Magnetic manipulation is another important advantage of magnetic nanoparticles [450]. It is done by labeling cells with magnetic nanoparticles that can easily be controlled by remote control or external magnetic field [451]. The magnetic nanoparticles, which are usually smaller than $10 \mathrm{~nm}$ can be easily transported through skin lipid matrix and hair follicles to the stratum granulosum, where it is condensing between corneocytes [452].

In orthopedic surgery, implant-associated infection is a serious issue, as stated in the previous sections. Infection around a bone graft can lead to serious illness or failure of surgery. Drug-loaded $\mathrm{Fe}_{3} \mathrm{O}_{4}$ composites promote cell adhesion, proliferation, and osteogenic differentiation of hBMSCs [453-455]. In stem cell therapy for bone regeneration, an application of these NPs is the magnetic targeting of stem cells to the deserved locations, known as magnetic homing of stem cells. For example, penetration of ferumoxide-labeled cells into porous hydroxyapatite ceramic implanted in a rabbit ulnar defect was significantly facilitated by this approach, which improved bone formation even in the chronic process [456].

\subsubsection{Summary and Statistical Analysis of the Survey on Inorganic Nanobiomaterials}

The survey on inorganic nanobiomaterials presented in Section 2.2 covered some 230 articles, practically the same as its counterpart for organic biomaterials not counting about 30 articles on fabrication techniques of silica and magnetic nanoparticles.

While the number of technical papers appears to be rather uniformly distributed among the ten types of inorganic nanomaterials considered in this survey, it should be noted that most studies focused on nanoparticles and their functionalization for drug/gene/therapy delivery, cell labeling, biosensing, and bioimaging $(75 \%)$, followed by studies on development and fabrication of new composite materials and scaffolds $(25 \%)$.

Gold and titania present the largest variety of nanostructures and the latter material may also be available in the form of nanotubes. Gold nanoparticles may represent the best solution for most applications in view of the possibility of controlling size and dimensions of nanostructures as well as for their special physical properties (for example, local plasmon resonance). However, massive 
utilization of GNPs is obviously limited by the high cost of gold. Silica and titania nanoparticles also are widely utilized as standalone materials or in combination with gold and silver nanoparticles.

Similar to what has been observed for organic nanobiomaterials, a rapidly growing research area in the field of inorganic nanobiomaterials for bone tissue engineering is to hybridize them with other materials (e.g., chitosan, PLA, PLGA, collagen, and hydroxyapatite) to enhance mechanical properties, biocompatibility and osteogenetic properties of the modified materials. Development of high-performance scaffolds comprised of multiple materials is the final stage of this complicated process.

\section{Applications of Nanobiomaterials}

Nanobiomaterials have outstanding mechanical, chemical, electrical and optical properties, which make them highly suited for a variety of biological applications [70]. Nanotechnologies made it possible to develop new nanoscale materials (nanobiomaterials) with upgraded surface area to volume ratio, enabling more surface interactions [457-459]. As nanobiomaterials possess very specific properties that may be tailored to specific targets (i.e., solubility (for otherwise insoluble drugs), carriers for hydrophobic entities, multifunctional capability, active and passive targeting, ligands (size exclusion), and reduced toxicity), they have tremendous potential for disease identification (as imaging tools), care delivery, and prevention in new ways [107]. Nanobiomaterials are special kinds of materials that are introduced into the body for the treatment of damaged hard tissues [460]. The huge variety of biomedical applications of nanobiomaterials are illustrated in Figure 22 [428,461-463].

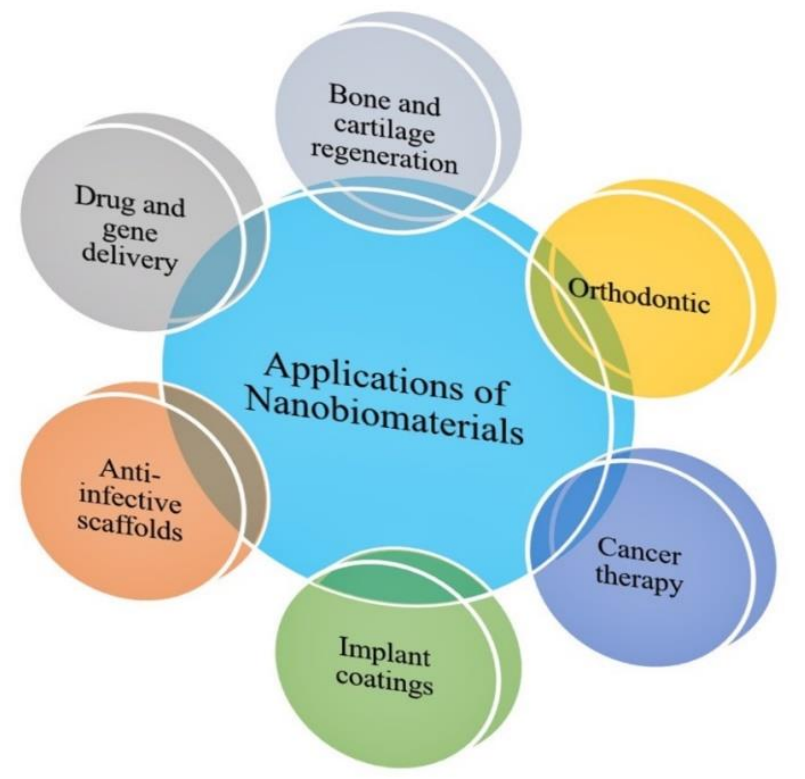

Figure 22. Applications of nanobiomaterials in the biomedical field.

Nanobiomaterials have well-defined nanostructures such as size, shape, channels, pore structure, and surface domain [464]. Nanoscale dimension enables nanobiomaterials to develop critical physical and chemical characteristics that enhance their performance $[465,466]$. The properties and behaviors of nanobiomaterials, therefore, allow the diagnosis, monitoring, treatment, and prevention of diseases [467]. Nano-size materials show more catalytic reactions at their surface than macro-sized or conventional materials [468]. The nanoscale biomaterials create biomimetic feature towards most of the proteins which support further biological reactions such as cell attachment, growth, proliferation and generation of new tissue [36]. 


\subsection{Bone Regeneration}

A perfect bone and cartilage repair scaffold materials should neither suppress the activity of normal cells nor induce toxicity during and after implantation [469]. Figure 23 illustrates the basic cycle of tissue regeneration using nanobiomaterials or derived scaffolds [255].

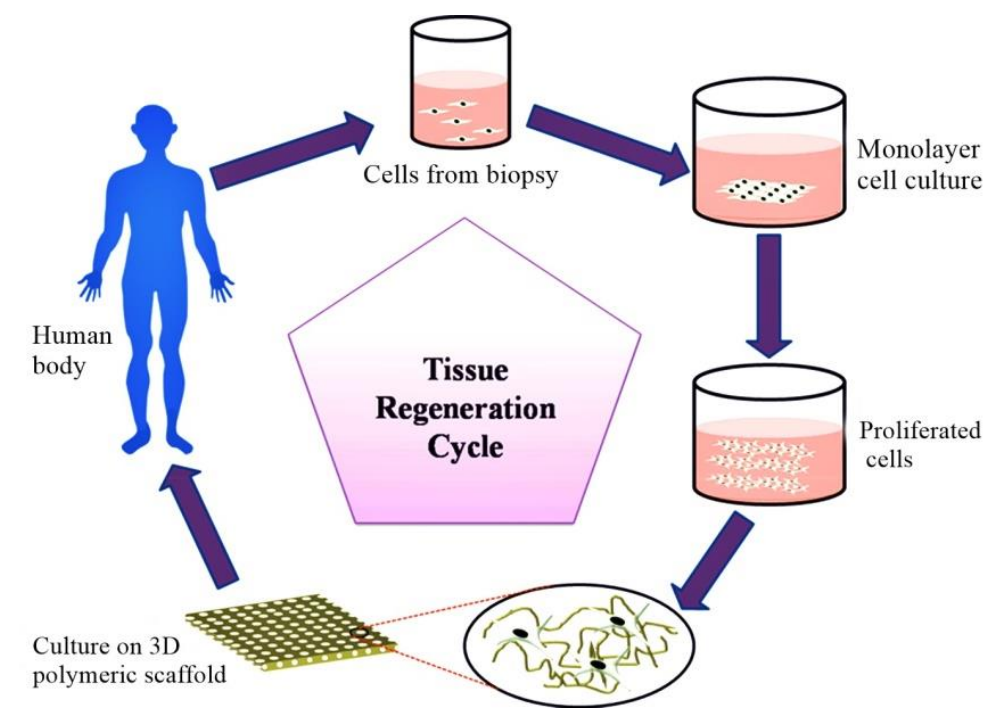

Figure 23. Basic principle procedures for tissue engineering. (Adapted with permission from @2019 American Chemical Society [255]).

The various synthetic nanostructured matrices are able to stimulate cell differentiation with a focus on preserving the structural features, composition, and biology of natural bone tissue [470]. The main constituents used so far in this regard are nano-hydroxyapatite [471], anodized titanium [472], collagen [473], and silver-incorporated calcium silicate. Nanobiomaterials (1-100 nm) generated from polymers, metals, ceramics, and composites act as effective constituents for hard tissue and play a significant role in osteointegration on nanostructured surfaces [474].

Alumina has been widely used for the fabrication of knee and hip joint prosthesis with low wear rates [475]. Bioactive glasses were used as a prosthesis for the restoration of the ossicular chain of the middle ear and oral implant to preserve the alveolar ridge from bone resorption [476,477]. Different metal oxides such as $\mathrm{ZnO}, \mathrm{Fe}_{2} \mathrm{O}_{3}, \mathrm{TiO}_{2}$, and $\mathrm{Al}_{2} \mathrm{O}_{3}$, and polymers such as PLA, PGA, and their copolymers were used with bioactive glass systems for hard tissue engineering applications [478,479].

\subsection{Drug Delivery}

As mentioned above, various nanobiomaterials can be used for bone regeneration, prevention of infections, and osteointegration [480,481]. A nanoparticle that functions as carrier can stabilize the bioactive molecules through encapsulation [482], facilitating targeting cellular delivery and targeted drug release $[483,484]$. Nanospheres, tubes and capsules are widely accepted tools for targeted and sustained release drug delivery because of their small size and high specific surface area, which encapsulates the drug molecules and shows high reactivity to the surrounding tissues [485]. The materials selected for nanosphere fabrication depend on application principles and requirements. Some factors in this regard include size, drug characteristics, surface properties, biodegradability and biocompatibility of materials and drug release profile [486]. The 2D and 3D structures of scaffolds can be useful for the drug (poorly soluble drugs) loading purpose in tissue engineering (Figure 24). 


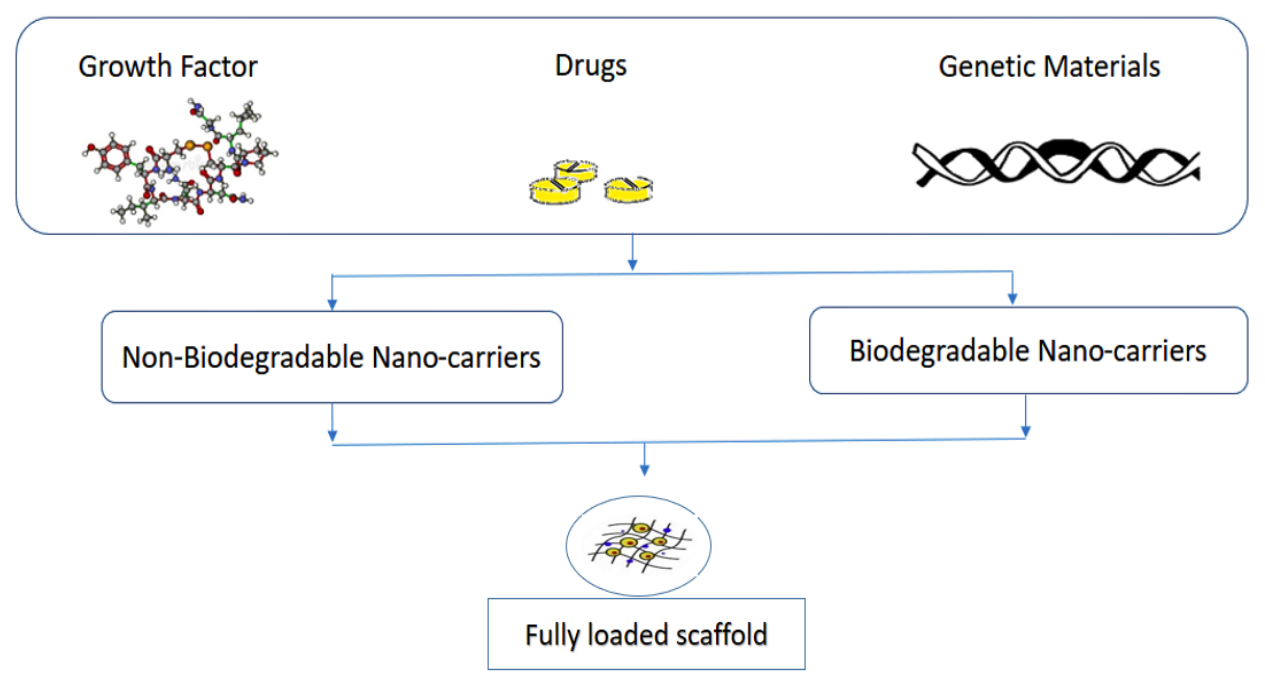

Figure 24. Drugs and biomolecules loaded scaffold for tissue engineering.

\subsection{Gene Delivery}

The rapid development of nanotechnology made available novel DNA and RNA delivery systems for gene therapy (Figure 25) that can be used instead of viral vectors [487]. Gene therapy collectively refers to therapies aimed at manipulating gene expression in living organisms by supplying exogenous DNA or RNA that is incorporated or not incorporated to cure or prevent diseases [488]. There is great incentive to work towards safer and targeted viral vectors and to engineer more effective non-viral systems that can achieve secure, effective gene therapy in humans because of the enormous potential for gene therapies to influence medicine.

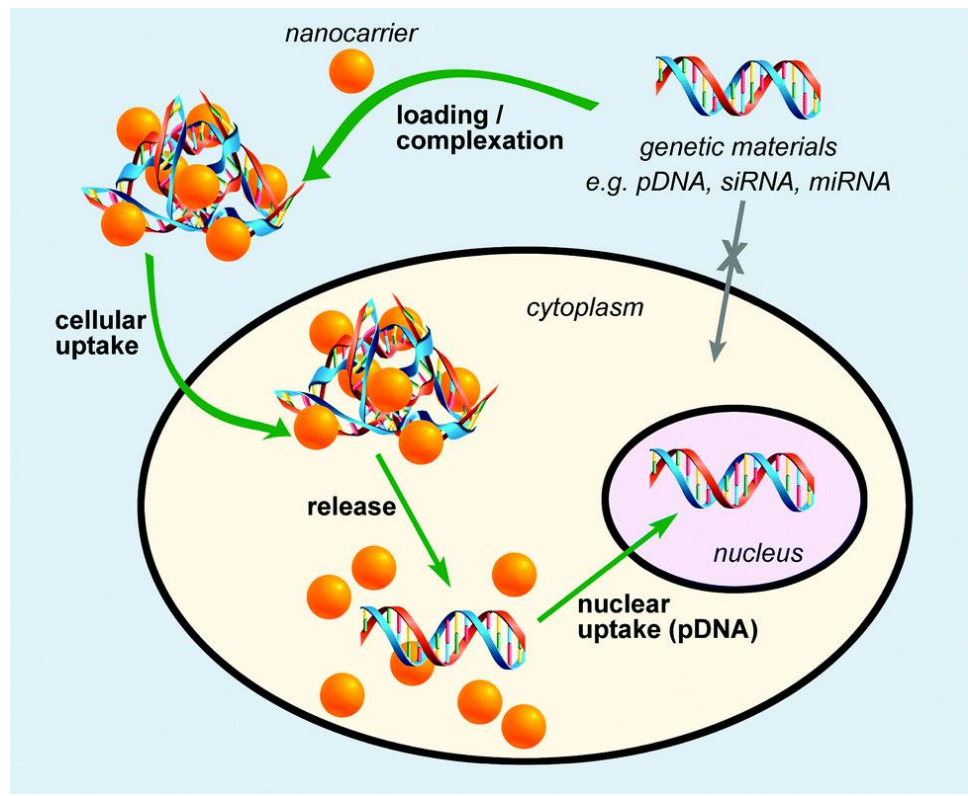

Figure 25. Fundamental steps of gene delivery by nanocarriers (orange spheres). (Adapted with permission from (C2016 Royal Society of Chemistry [489]).

There are a number of nanocarriers used for gene delivery (Figure 25) [489] applications which are based on lipids [490,491], liposomes [492-494], dendrimers [495], polymers [496,497], graphene [498,499], carbon nanotubes (CNTs) [500,501], mesoporous silica [502], gold nanoparticles [503,504], magnetic nanoparticles $[505,506]$, and other types of inorganic nanoparticles. 
The number of clinical trials for cancer [507], liver disease [508], hemophilia [509], and bone regeneration [510-512] is continuously increasing due to the promising opportunity to correct gene disorders. Nanomaterials are used for gene delivery because of their small size and superior stability [513]. Before the use of these nanomaterials, surfaces need to be functionalized with small biomolecules or polymers to adapt their physiochemical properties such as hydrophobicity, charge density, and binding affinity [514,515]. Factors including molecular weight, biodegradability, rigidity, charge density, pKa value, solubility, crystallinity, and hydrophobicity ensure effective and safe gene delivery $[516,517]$.

Surface-modified graphene oxide through cationic polymers such as polyethylenimine (PEI) provides a large surface area for the encapsulation of DNA molecules [518]. DNA/drug molecules attached graphene oxide conjugated provide an outstanding platform for the immobilization of nucleotides on its surface [519]. Mesoporous silica nanospheres (MSNs) and functionalized single-walled carbon nanotubes (SWCNT) represent an excellent gene delivery system [520]. In Figure 26, a potential route is recorded for the use of dendrimers as vectors of gene delivery. As plasmid DNA penetrates the cell membrane, it makes (in vitro) a complex between dendrimer and DNA (called dendriplex). This complex is transported through the blood system to the specific cell. Finally, the DNA moves through the cytoplasm to reach the nucleus for gene expression in series $[521,522]$.

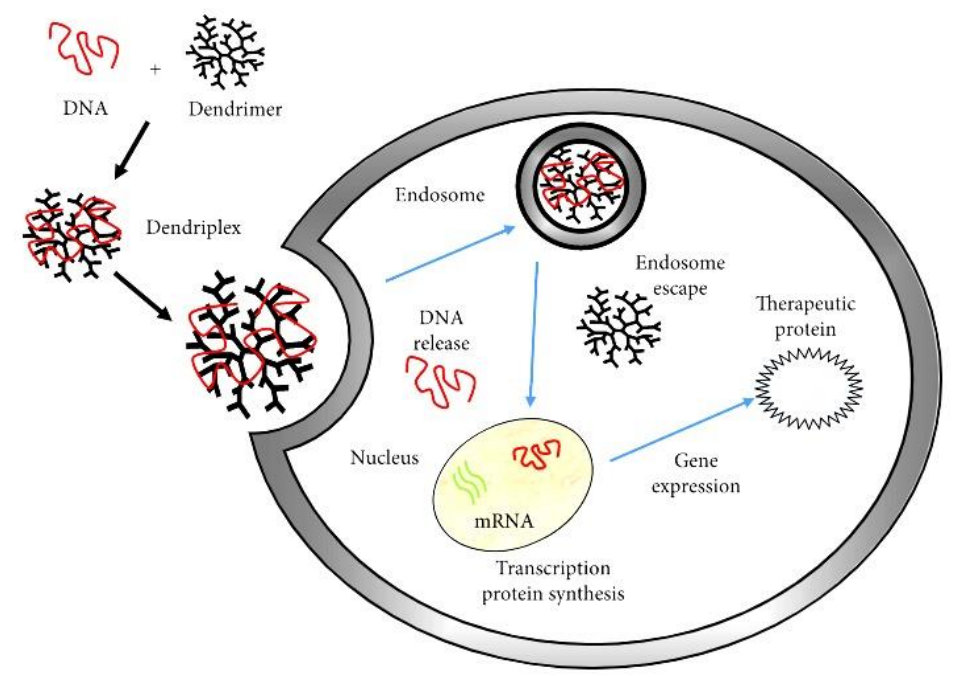

Figure 26. Schematic diagram for a possible route in the use of dendrimers as gene delivery vectors.

\subsection{Anti-Infective Nanobiomaterials}

Disease, injury, and trauma can lead to serious bacterial infections, which cause disease and adverse complications in host tissues and even death of patients [523]. Nanobiomaterials made from polymers, metals, and ceramics might be a potential source of infection when they are introduced into the body [524,525]. Virus and bacterial infections cause unregulated damage that leads to organ failure [526]. In polymeric biomaterials, the most common bacterial infections are powered by Staphylococcus epidermidis (S. epidermidis) from skin and Staphylococcus aureus (S. aureus), which may identified on metallic biomaterials [527]. Ceramics and metals can represent an alternative because of their resistance to infection. However, in presence of minor imperfections on the surface or microfractures, pathogens, such as bacteria, can form a colony [528]. Biomaterials from natural sources were used as alternative as scaffolds for promoting regeneration but they carry a risk for pathogenic transmission [529]. 


\subsection{Nanobiomaterials for Coating}

Micro/nanoscale tissue engineering scaffolds play a vital role on the organization of natural extracellular matrix [530]. Nanostructured 3D scaffolds enhance cell functioning, migration, differentiation, proliferation, and extracellular matrix formation [531].

Nanobiomaterials used for coatings include silica $\left(\mathrm{SiO}_{2}\right)$, titania $\left(\mathrm{TiO}_{2}\right)$, zirconia $\left(\mathrm{ZrO}_{2}\right)$, alumina $\left(\mathrm{Al}_{2} \mathrm{O}_{3}\right)$, zinc oxide $(\mathrm{ZnO}), \mathrm{CNT}$, graphene, and various combined oxides [532]. Simple calcium phosphate coating method on metals, glasses, inorganic ceramics and organic polymers (such as PLGA, PS, PP, and silicone), collagens, and silk fibers can improve biocompatibility or enhance the bioreactivity for orthopedic applications $[494,533] . \mathrm{TiO}_{2}$ and $\mathrm{Al}_{2} \mathrm{O}_{3}$ can be used as biologically active coating agents, supporting cell adhesion, growth, osteogenic differentiation, bone matrix production, and mineralization [534]. Nanostructured $\mathrm{TiO}_{2}$ has a positive effect on the performance of bone cells. $\mathrm{TiO}_{2}$ is available in the form of nanocrystals [535], nanofibers [536], nanoparticles [537], also immobilized on nanotubes [538]. $\mathrm{TiO}_{2}$ nanotube coating on any substrate enhances hydroxyapatite formation in SBF [539]. Nano silica coating on Ti-6Al-4V alloys generates apatite and supports adhesion and attachment of human osteoblast-like Saos-2 cells [540]. Nitinol coated stainless steel has shown enhanced biocompatibility but $\mathrm{Ni}$ ions produce an allergic response and toxicity [541]. Zirconia coated pure and yttrium-stabilized nanostructure promote deposition of apatite from SBF, which supports cell adhesion and growth [542]. Zinc oxide doped with alumina or functionalized with the silane coupling agent KH550 supports the proliferation of fibroblasts [543].

Carbon nanotubes have been used with various synthetic and natural polymers or minerals for the improvement of mechanical properties [544]. CNT and other nano-carbon forms stimulate cell adhesion and growth of osteogenic cells. Graphene-based films and composites used for biomaterial coatings can be obtained from pure or oxidized graphene. These graphene-based films improve the osteogenic differentiation manifested by collagen I and osteocalcin, high calcium phosphate deposition, and high alkaline phosphatase activity $[545,546]$. Due to the antimicrobial impression of graphene, graphene oxide (GO), and their derivatives, these materials can be used for implant coating [547]. Graphene oxide (GO) coating on the collagen scaffold induces morphological changes depending on GO concentration [548]. The application of GO improved physical properties like compressive strength as well as adsorption of $\mathrm{Ca}$ and proteins without changing porosity [549]. Graphene oxide-silk fibroin (GO-SF) composite used as an alternative to coating with collagen, showed improved biomechanical properties and proved could work in cellular environments [550].

HA can accelerate new bone formation by coating on titanium and tantalum scaffolds. It was demonstrated that after 6 weeks of implantation with titanium and tantalum scaffolds coated is possible to reach fully dense bone formation [551]. Calcium-phosphate-coated Fe foam showed better differentiation and proliferation rate of human mesenchymal stem cells than uncoated Fe foam [552]. Polymer-coated mesoporous silica nanoparticles are effective, cell-specific targeted chemotherapeutic agent delivery method [553]. In rat calvarial defects, HA-coated PLGA scaffolds alone promote bone regeneration and increased exposure to HA nanoparticles on the scaffold surface has been documented to result in accelerated bone deposition by local progenitors [554].

\subsection{Nanostructured Scaffolds}

Scaffolds are artificial constructs that provide support, tensile strength, and aid in tissue ingrowth [555]. They can also serve as carriers for growth factors, drugs and other required ingredients [556]. Scaffolds mimic the presence of extracellular matrix and allow the replacement of tissue without producing any harmful disturbance with respect to surrounding tissues. An ideal scaffold should be biocompatible, biodegradable, bioactive, non-toxic, mechanically stable, biodegradable, and bioresorbable (Figure 27) [557]. The amalgamation of organic and inorganic materials with scaffolds may enhance morphology and mechanical properties, thus supporting better cell attachment and proliferation [558]. 


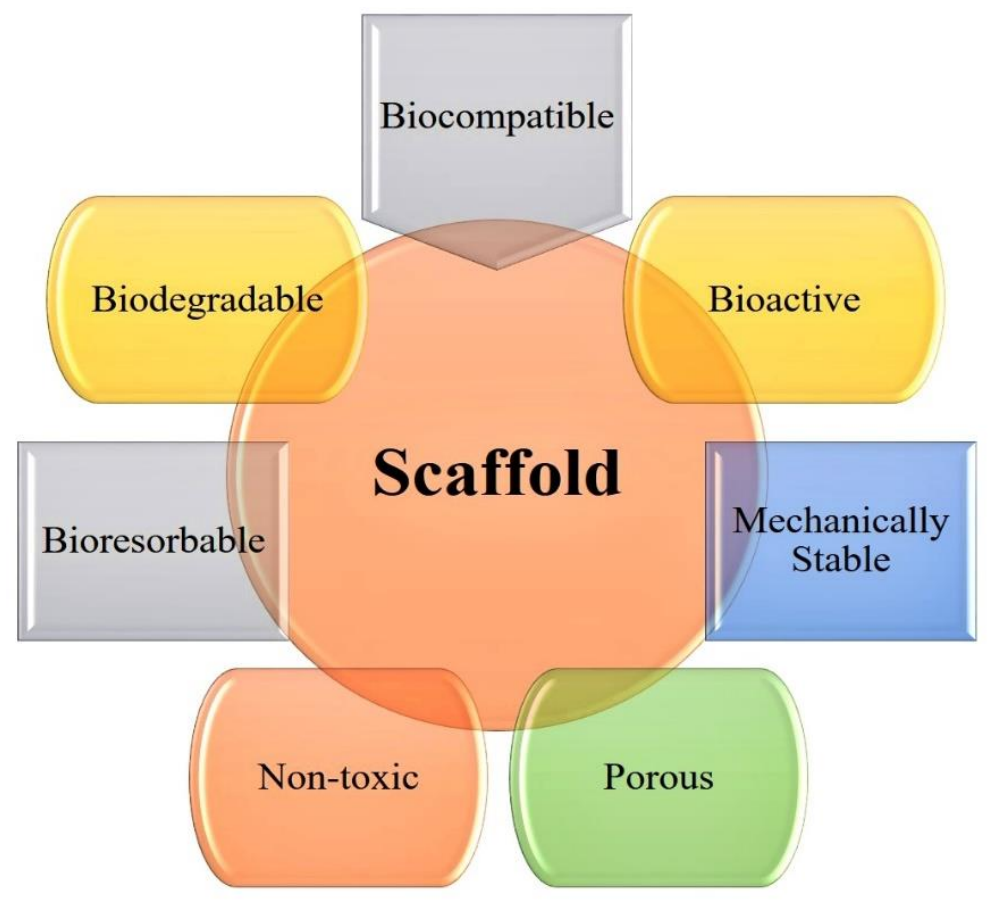

Figure 27. Desired properties of an ideal scaffold.

Scaffold properties can be improved by using nanoparticles because organic and inorganic minerals in natural bone have nanoscale structures [559]. Many studies found that the addition of titanium and iron improve biological and mechanical properties such as collagen synthesis and apatite generation [560,561]. In addition, engineered nanofibrous scaffolds are also suitable for loadbearing applications and can replace natural extracellular matrix (ECM) with artificial ECM. The nanofibrous scaffold can therefore get a much more suitable environment for cellular growth and eventual regeneration of the bone [562]. Nanofiber-based scaffolds have been fabricated by using different synthetic polymers including PCL [563-566], PLLA [567,568], copolymer [569], PLGA [61], and chitosan [569].

Different kinds of metallic nanoparticles can be used for the synthesis of composite-based scaffolds with enhanced mechanical characteristics, cell adhesion, and bone tissue generating capacity [12]. The incorporation of titanium, iron, and alumoxane in a scaffold can improve mechanical properties, collagen synthesis, calcium deposition, and alkaline phosphatase activity [561].

Graphene and its derivatives were used as reinforcement material for fibrous scaffolds, films, and hydrogels [570]. The graphene and graphene oxide incorporation into hydrogels yield enhancements in mechanical properties without producing adverse effects on encapsulated fibroblast cells [571]. Carbon-based nanomaterials can be used to improve mechanical strength of scaffolds [572]. Alumina, titania, bioglass, and hydroxyapatite support osteoblast adhesion and growth [573].

Nanobiomaterial-based composite structures are an efficient platform for the synthesis of engineered scaffolds and application in bone tissue engineering (Figure 28) [574]. Nanocomposite-based scaffolds exhibit inherent characteristics such as porous and rough surface and increased wettability, which promote fast bone regeneration. These nanocomposite-based scaffolds provide a porous structure for nutrients exchange and increased protein adsorption. Scaffolds exhibited micro/nano-scaled porous structural pathway for cell-scaffold interaction and integrin-triggered signaling pathway. The nanoscale features support bone cells (osteoblast) and bone-derived stem cells proliferation, migration, cell signaling, stem cell fate, and genetic cell fate. The nanobiomaterials based scaffold have notable mechanical and biological advantages and can induce bone tissue regeneration [531]. The nanostructured materials improve morphological characteristics of scaffolds that may enhance 
osteoinduction, bone cell attachment, differentiation, proliferation, and natural bone cell growth within the extracellular matrix [12].

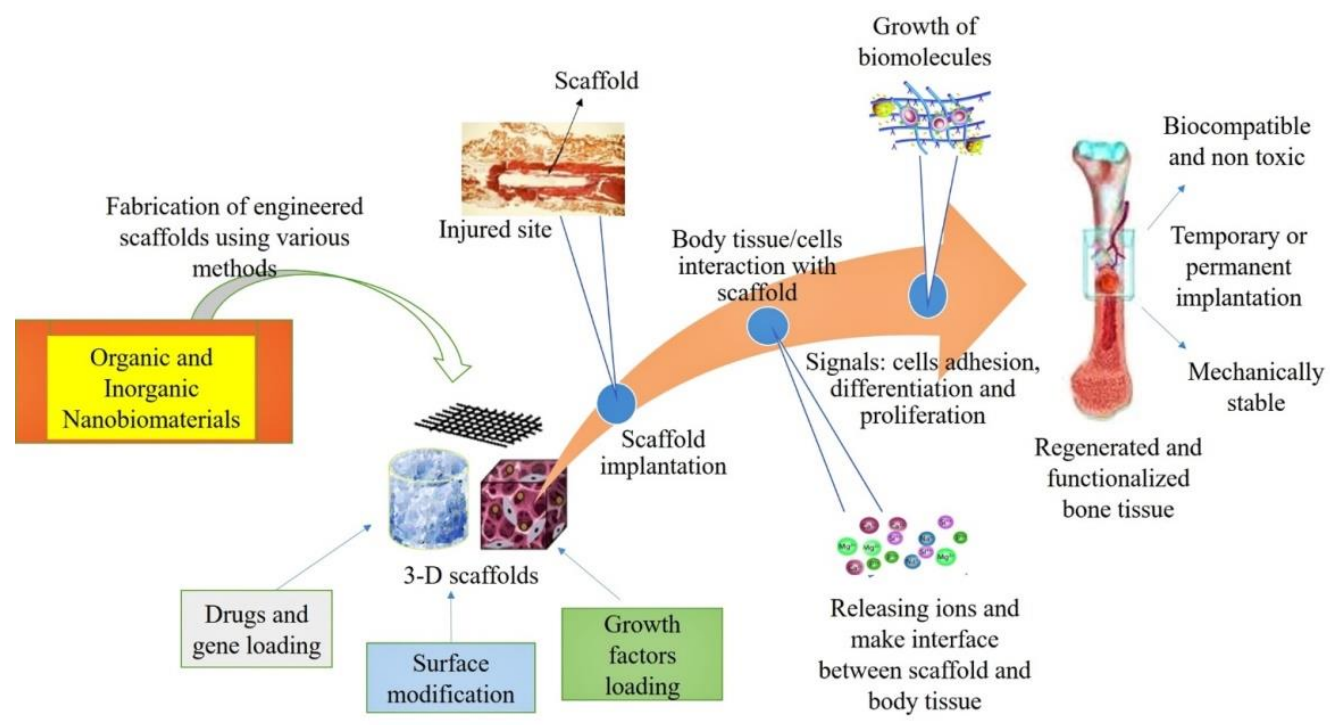

Figure 28. Engineered organic and inorganic nanobiomaterials for hard tissue engineering applications.

Hydroxyapatite (HA) has attracted attention because of its inherent biological compatibility and bone conduction as well as its similarity with bone minerals [575]. For this reason, HA was combined with a number of synthetic and natural polymers such as polycaprolactone [576], poly (lactic acid) (PLA) [577], polyethylene, poly(lactic-co-glycolic acid) (PLGA) [203], collagen [578], gelatin [148], and chitosan [579] to fabricate scaffolds. These composite based scaffolds showed improved mechanical properties, porosity and biocompatibility without or with significantly less adverse effects.

\subsection{Bone Cancer Therapy}

Cancer is the uncontrolled growth of tissues that could lead to invasion into other organs without proper regulation or differentiation [580]. Conventional cancer therapy is associated with multiple adverse side effects [581]. Bone metastases or "bone mets" occur when cancer cells from the primary tumor relocate to the bone and also spread in the prostate, breast, and lung, which leads to painful (75\% of patients) and devastating skeletal-related events (SREs) [582,583]. Depending on the stage of the disease, history, and the overall health of the patient, disease management includes a combination of therapies as shown in Figure 29 [584].

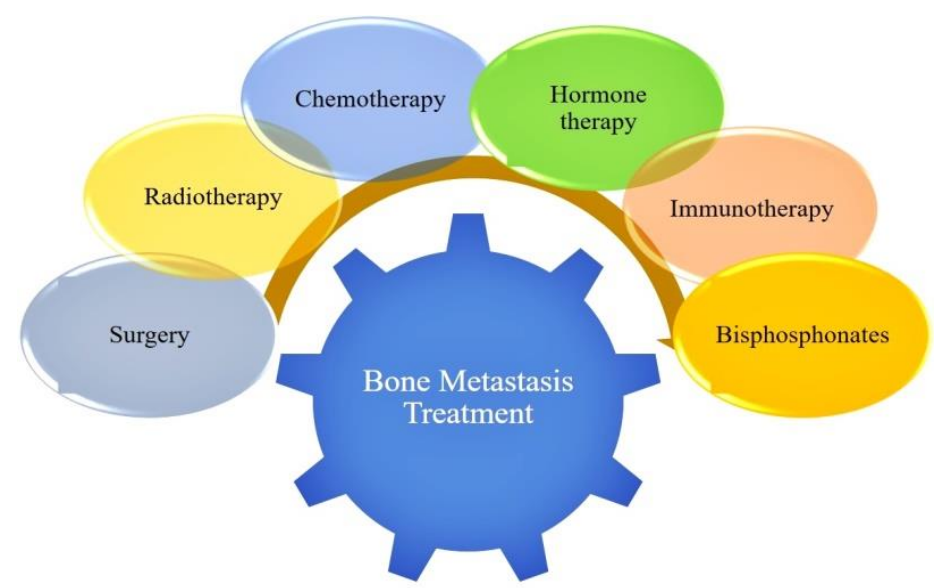

Figure 29. Bone metastasis management through combination of therapies. 
The different types of nanoparticles (NPs) used as carriers for small-molecule drugs, proteins, and nucleic acids [585] can be localized to specific disease locations for the treatment of bone metastasis [586]. Nanoparticles also improve the efficiency of other methods used for treating bone metastasis [587]. The effectiveness of NPs depends on their accumulation in vascularized solid tumors via the enhanced permeability and retention (EPR) effect [588]. A wide variety of nanomaterials have been developed in the 1 to $100 \mathrm{~nm}$ range and include various anti-tumor drugs (Figure 30) by fine-tuning the chemical structure, scale, and shape (morphology) that can regulate the nanomaterials' functionality [589].
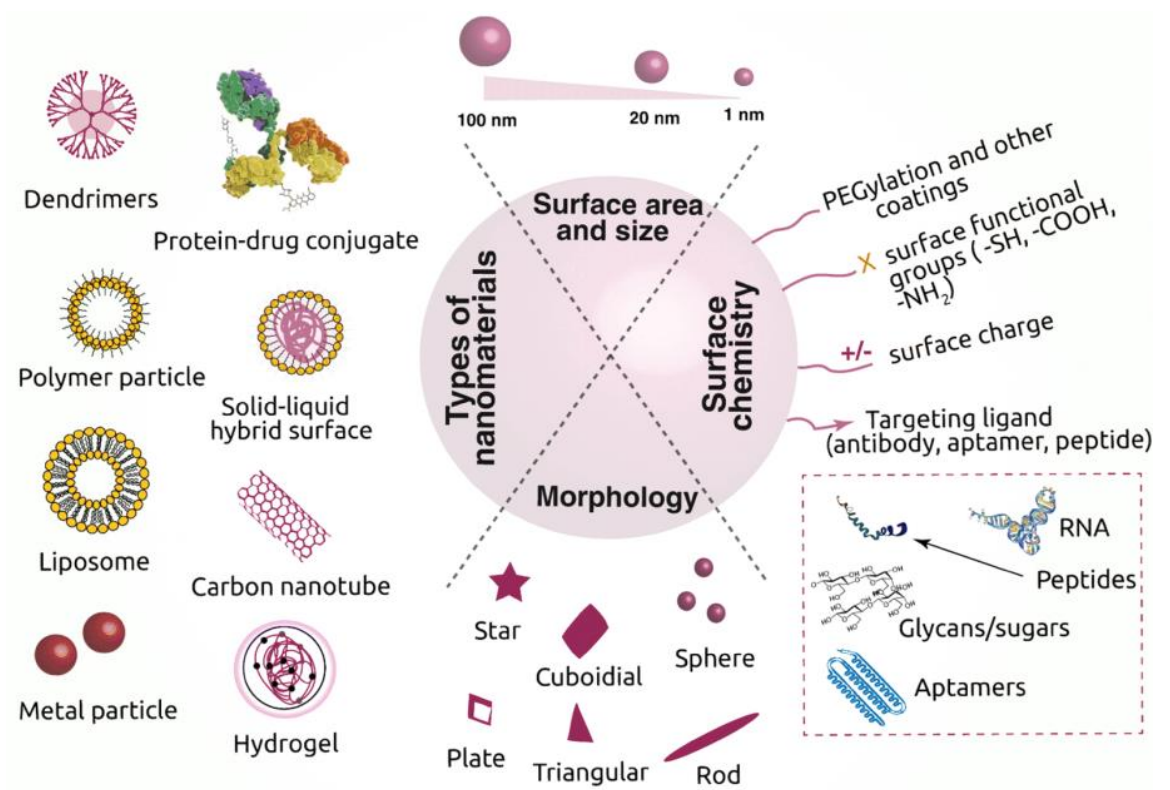

Figure 30. Schematic representation of different types of nanomaterials and their drug-loaded conjugates employed in cancer therapy. (Adapted with permission from (C2019 Springer [589]).

\section{Counter-Indications}

There is inevitably some sort of interaction between the organic or inorganic materials and the biological environment when individual or composite biomaterials are put in contact with the tissues and fluids of the human body. The basic clinical research may decide that the materials should not cause any local or systemic adverse reactions. Recent studies exposed that nanosized materials can easily penetrate biological membranes of normal cells and enter vascular system to facilitate redistribution in different tissues. Nanomaterials, which by themselves are not very harmful, could become toxic if are ingested in higher concentration. The toxicity of metal based biomaterials to the liver is an important basis for the safety assessment of nanosized materials. Metal based nanoparticles release ions which may enter the cells and affect the functions of organelles, leading to liver injury. Various factors including amount, composition, $\mathrm{pH}$, and fabrication techniques may decide the compatibility and cytotoxicity of biomaterials. The research is ongoing to improve the existing technologies which may produce highly compatible substitutes without producing adverse effects.

\section{Conclusions}

This review article provided a broad overview of the various types of organic and inorganic nanobiomaterials and their applications in the field of hard tissue engineering. Besides classifying nanobiomaterials, the survey covered several key aspects like bone/cartilage regeneration, drug/gene delivery, anti-infection properties, coatings, scaffold fabrication, and cancer therapy. A total of 550 articles selected by means of web search engines widely used in science and engineering were reviewed 
in this study. Interestingly, the number of reviewed articles was approximately the same for organic and inorganic biomaterials.

Biomaterials science is a highly multidisciplinary area. Developments in life science and nanotechnology enabled scientists and engineers to conceive new designs and improve the existing bone structure. For example, advances in nanotechnology allowed for the development of novel methods for fabricating new nanostructured scaffolds possessing a higher efficiency in tissue regeneration.

Nanomaterials represent an excellent tool for research and therapeutic approaches in bone tissue engineering. Organic nanomaterials are more biocompatible, nontoxic, and help more with cell regeneration than inorganic nanomaterials. However, inorganic nanomaterials provide better mechanical strength and inertness to chemical agent. From the references cited in this survey it appears that nanoparticles, graphene and nanocomposites are the most diffused types of nanostructures used for hard tissue applications. An important research trend which results in a rapidly growing number of published articles is the development of new composite nanobiomaterials especially for scaffold applications.

Interactions between bone cells and nanomaterials depend on the composition of nanoparticles. Proper selection of nanoparticles may result in faster bone regeneration and recovery. Besides composition, the overall performance of a nanobiomaterial depends on porosity, microstructure, mechanical properties and functionality. Nanomaterials-based scaffolds also play a major role in three-dimensional tissue growth. Nanostructural modifications provide a favorable environment for bone regeneration.

The survey presented in the article proved that tissue engineering supports (i) application of engineering design methods to functionally engineered tissues, (ii) development of novel biomaterials for constructing scaffolds that mimic extracellular matrix, and (iii) creating artificial microenvironments. Nanobiomaterials represent an excellent tool for research and therapeutic approaches in bone tissue engineering. However, further investigations should be aimed at producing advanced nanobiomaterials suitable for hard tissue engineering that can fill the gap between biomaterial fabrication and clinical implementation.

Funding: This research received no external funding.

Conflicts of Interest: The authors declare no conflict of interest.

\section{References}

1. Patra, J.K.; Das, G.; Fraceto, L.F.; Campos, E.V.R.; Rodriguez-Torres, M.d.P.; Acosta-Torres, L.-S.; Diaz-Torres, L.A.; Grillo, R.; Swamy, M.K.; Sharma, S.; et al. Nano based drug delivery systems: Recent developments and future prospects. J. Nanobiotechnol. 2018, 16, 71. [CrossRef]

2. Parratt, K.; Yao, N. Nanostructured biomaterials and their applications. Nanomaterials 2013, 3, $242-271$. [CrossRef] [PubMed]

3. Lei, Y.; Lijuan, Z.; Webster, T.J. Nanobiomaterials: State of the art and future trends. Adv. Eng. Mater. 2011, 13, B197-B217.

4. Ramos, A.P.; Cruz, M.A.E.; Tovani, C.B.; Ciancaglini, P. Biomedical applications of nanotechnology. Biophys. Rev. 2017, 9, 79-89. [CrossRef] [PubMed]

5. Capek, I.B.T.-S. Nanocomposite Structures and Dispersions; Elsevier: Amsterdam, The Netherlands, 2006; Chapter 1, Volume 23, pp. 1-69.

6. Florencio-Silva, R.; Rodrigues, G.; Sasso-Cerri, E.; Simões, M.J.; Cerri, P.S.; Cells, B. Biology of bone tissue: Structure, function, and factors that influence bone cells. BioMed Res. Int. 2015, 2015, 421746. [CrossRef]

7. Eliaz, N.; Metoki, N. Calcium phosphate bioceramics: A review of their history, structure, properties, coating technologies and biomedical applications. Materials 2017, 10, 334. [CrossRef]

8. McMahon, R.; Wang, L.; Skoracki, R.; Mathur, A. Development of nanomaterials for bone repair and regeneration. J. Biomed. Mater. Res. Part B Appl. Biomater. 2013, 101, 387-397. [CrossRef] [PubMed]

9. Kalenderer, Ö.; Turgut, A. Bone. In Musculoskeletal Research and Basic Science; Korkusuz, F., Ed.; Springer International Publishing: Cham, Switzerland, 2016; Chapter 18, pp. 303-321. 
10. Farbod, K.; Nejadnik, M.R.; Jansen, J.A.; Leeuwenburgh, S.C.G. Interactions between inorganic and organic phases in bone tissue as a source of inspiration for design of novel nanocomposites. Tissue Eng. Part B Rev. 2013, 20, 173-188. [CrossRef]

11. Feng, Q.L.; Wu, J.; Chen, G.Q.; Cui, F.Z.; Kim, T.N.; Kim, J.O. A mechanistic study of the antibacterial effect of silver ions on Escherichia coli and Staphylococcus aureus. J. Biomed. Mater. Res. 2000, 52, 662-668. [CrossRef]

12. Walmsley, G.G.; Mcardle, A.; Tevlin, R.; Momeni, A.; Atashroo, D.; Hu, M.S.; Feroze, A.H.; Wong, V.W.; Lorenz, P.H.; Longaker, M.T.; et al. Nanotechnology in bone tissue engineering. Nanomedicine 2015, 11, 1253-1263. [CrossRef]

13. Mohamed, A.M. An overview of bone cells and their regulating factors of differentiation. Malays. J. Med. Sci. 2008, 15, 4-12. [PubMed]

14. Kargozar, S.; Mozafari, M.; Hamzehlou, S.; Brouki Milan, P.; Kim, H.-W.; Baino, F. Bone tissue engineering using human cells: A Comprehensive review on recent trends, current prospects, and recommendations. Appl. Sci. 2019, 9, 174. [CrossRef]

15. Combes, C.; Cazalbou, S.; Rey, C. Apatite biominerals. Minerals 2016, 6, 34. [CrossRef]

16. Glimcher, M. Bone: Nature of the calcium phosphate crystals and cellular, structural, and physical chemical mechanisms in their formation. Rev. Miner. Geochem. 2006, 64, 223-282. [CrossRef]

17. Stevens, M.M. Biomaterials for bone tissue engineering. Mater. Today 2008, 11, 18-25. [CrossRef]

18. Liu, S.; Gong, W.; Dong, Y.; Hu, Q.; Chen, X.; Gao, X. The effect of submicron bioactive glass particles on in vitro osteogenesis. RSC Adv. 2015, 5, 38830-38836. [CrossRef]

19. Cheng, C.W.; Solorio, L.D.; Alsberg, E. Decellularized tissue and cell-derived extracellular matrices as scaffolds for orthopaedic tissue engineering. Biotechnol. Adv. 2014, 32, 462-484. [CrossRef]

20. Nie, X.; Wang, D.-A. Decellularized orthopaedic tissue-engineered grafts: Biomaterial scaffolds synthesised by therapeutic cells. Biomater. Sci. 2018, 6, 2798-2811. [CrossRef]

21. Amini, A.R.; Laurencin, C.T.; Nukavarapu, S.P. Bone tissue engineering: Recent advances and challenges. Crit. Rev. Biomed. Eng. 2012, 40, 363-408. [CrossRef]

22. Zhang, L.; Webster, T.J. Nanotechnology and nanomaterials: Promises for improved tissue regeneration. Nano Today 2009, 4, 66-80. [CrossRef]

23. Kim, S.; Kim, D.; Cho, S.W.; Kim, J.; Kim, J.-S. Highly efficient RNA-guided genome editing in human cells via delivery of purified Cas9 ribonucleoproteins. Genome Res. 2014, 24, 1012-1019. [CrossRef] [PubMed]

24. Wang, C.; Shen, H.; Tian, Y.; Xie, Y.; Li, A.; Ji, L.; Niu, Z.; Wu, D.; Qiu, D. Bioactive nanoparticle-Gelatin composite scaff old with mechanical performance comparable to cancellous bones. ACS Appl. Mater. Interfaces 2014, 6, 13061-13068. [CrossRef] [PubMed]

25. Dhivya, S.; Ajita, J.; Selvamurugan, N. Metallic nanomaterials for bone tissue engineering. J. Biomed. Nanotechnol. 2015, 11, 1675-1700. [CrossRef] [PubMed]

26. Moreno-Vega, A.I.; Gómez-Quintero, T.; Nuñez-Anita, R.E.; Acosta-Torres, L.S.; Castaño, V. Polymeric and ceramic nanoparticles in biomedical applications. J. Nanotechnol. 2012, 2012, 936041. [CrossRef]

27. Kim, N.J.; Lee, S.J.; Atala, A. Biomedical nanomaterials in tissue engineering. In Woodhead Publishing Series in Biomaterials; Gaharwar, A.K., Sant, S., Hancock, M.J., Hacking, S.A.B.T.-N., Eds.; Woodhead Publishing: Cambridge, UK, 2013; pp. 1e-25e.

28. Gajanan, K.; Tijare, S.N. Applications of nanomaterials. Mater. Today Proc. 2018, 5, 1093-1096. [CrossRef]

29. Wang, Y.; Xia, Y. Bottom-up and top-down approaches to the synthesis of monodispersed spherical colloids of low melting-point metals. Nano Lett. 2004, 4, 2047-2050. [CrossRef]

30. Saiz, E.; Zimmermann, E.A.; Lee, J.S.; Wegst, U.G.K.; Tomsia, A.P. Perspectives on the role of nanotechnology in bone tissue engineering. Dent. Mater. 2013, 29, 103-115. [CrossRef]

31. Gardin, C.; Ferroni, L.; Favero, L.; Stellini, E.; Stomaci, D.; Sivolella, S.; Bressan, E.; Zavan, B. Nanostructured biomaterials for tissue engineered bone tissue reconstruction. Int. J. Mol. Sci. 2012, 13, 737-757.

32. España-Sánchez, B.L.; Cruz-Soto, M.E.; Elizalde-Pena, E.A.; Sabasflores-Benitez, S.; Roca-Aranda, A.; Esquivel-Escalante, K.; Luna-Barcenas, G. Trends in Tissue Regeneration: Bio-nanomaterials. In Tissue Rigeneration; El-Sayed Kaoud, H.A., Ed.; IntechOpen: Rijeka, Croatia, 2018.

33. Nikolova, M.P.; Chavali, M.S. Recent advances in biomaterials for 3D scaffolds: A review. Bioact. Mater. 2019, 4, 271-292. [CrossRef] 
34. Zhao, Z.Y.; Liang, L.; Fan, X.; Yu, Z.; Hotchkiss, A.T.; Wilk, B.J.; Eliaz, I. The role of modified citrus pectin as an effective chelator of lead in children hospitalized with toxic lead levels. Altern. Ther. Health Med. 2008, 14, 34-38.

35. Zheng, K.; Balasubramanian, P.; Paterson, T.E.; Stein, R.; MacNeil, S.; Fiorilli, S.; Vitale-Brovarone, C.; Shepherd, J.; Boccaccini, A.R. Ag modified mesoporous bioactive glass nanoparticles for enhanced antibacterial activity in 3D infected skin model. Mater. Sci. Eng. C 2019, 103, 109764. [CrossRef]

36. Chen, F.-M.; Liu, X. Advancing biomaterials of human origin for tissue engineering. Prog. Polym. Sci. 2016, 53, 86-168. [CrossRef] [PubMed]

37. John, $€$. Selected developments and medical applications of organic-inorganic hybrid biomaterials based on functionalized spherosilicates. Mater. Sci. Eng. C 2018, 88, 172-181. [CrossRef] [PubMed]

38. Fattahi, P.; Yang, G.; Kim, G.; Abidian, M.R. Biomaterials: A review of organic and inorganic biomaterials for neural interfaces. Adv. Mater. 2014, 26, 1793. [CrossRef]

39. Virlan, M.J.R.; Miricescu, D.; Radulescu, R.; Sabliov, C.M.; Totan, A.; Calenic, B.; Greabu, M. Organic nanomaterials and their applications in the treatment of oral diseases. Molecules 2016, 21, 207. [CrossRef] [PubMed]

40. Chellan, P.; Sadler, P.J. The elements of life and medicines. Philos. Trans. R. Soc. A Math. Phys. Eng. Sci. 2015, 373, 20140182. [CrossRef] [PubMed]

41. Kiaie, N.; Aavani, F.; Razavi, M. 2-particles/fibers/bulk. In Development and Evaluation; Razavi, M., Ed.; Woodhead Publishing: Cambridge, UK, 2017; pp. 7-25.

42. Wang, G.; Mostafa, N.Z.; Incani, V.; Kucharski, C.; Uludaĝ, H. Bisphosphonate-decorated lipid nanoparticles designed as drug carriers for bone diseases. J. Biomed. Mater. Res. Part A 2012, 100, 684-693. [CrossRef] [PubMed]

43. Zhang, G.; Guo, B.; Wu, H.; Tang, T.; Zhang, B.T.; Zheng, L.; He, Y.; Yang, Z.; Pan, X.; Chow, H.; et al. A delivery system targeting bone formation surfaces to facilitate RNAi-based anabolic therapy. Nat. Med. 2012, 18, 307-314. [CrossRef] [PubMed]

44. Liu, J.; Zhang, H.; Dong, Y.; Jin, Y.; Hu, X.; Cai, K.; Ma, J.; Wu, G. Bi-directionally selective bone targeting delivery for anabolic and antiresorptive drugs: A novel combined therapy for osteoporosis? Med. Hypotheses 2014, 83, 694-696. [CrossRef]

45. Hirsjärvi, S.; Sancey, L.; Dufort, S.; Belloche, C.; Vanpouille-Box, C.; Garcion, E.; Coll, J.-L.; Hindré, F.; Benoît, J.-P. Effect of particle size on the biodistribution of lipid nanocapsules: Comparison between nuclear and fluorescence imaging and counting. Int. J. Pharm. 2013, 453, 594-600. [CrossRef]

46. Nahar, M.; Dutta, T.; Murugesan, S.; Asthana, A.; Mishra, D.; Rajkumar, V.; Tare, M.; Saraf, S.; Jain, N.K. Functional polymeric nanoparticles: An efficient and promising tool for active delivery of bioactives. Crit. Rev. Ther. Drug Carr. Syst. 2006, 23, 259-318. [CrossRef] [PubMed]

47. An, S.Y.; Bui, M.-P.N.; Nam, Y.J.; Han, K.N.; Li, C.A.; Choo, J.; Lee, E.K.; Katoh, S.; Kumada, Y.; Seong, G.H. Preparation of monodisperse and size-controlled poly(ethylene glycol) hydrogel nanoparticles using liposome templates. J. Colloid Interface Sci. 2009, 331, 98-103. [CrossRef] [PubMed]

48. Monteiro, N.; Martins, A.; Reis, R.L.; Neves, N.M. Liposomes in tissue engineering and regenerative medicine. J. R. Soc. Interface 2014, 11, 281-297. [CrossRef] [PubMed]

49. Qi, R.; Majoros, I.; Misra, A.C.; Koch, A.E.; Campbell, P.; Marotte, H.; Bergin, I.L.; Cao, Z.; Goonewardena, S.; Morry, J.; et al. Folate receptor-targeted dendrimer-methotrexate conjugate for inflammatory arthritis. J. Biomed. Nanotechnol. 2014, 11, 1370-1384. [CrossRef]

50. Duncan, R.; Izzo, L. Dendrimer biocompatibility and toxicity. Adv. Drug Deliv. Rev. 2005, 57, $2215-2237$. [CrossRef]

51. De la Riva, B.; Sánchez, E.; Hernández, A.; Reyes, R.; Tamimi, F.; López-Cabarcos, E.; Delgado, A.; vora, C. Local controlled release of VEGF and PDGF from a combined brushite-chitosan system enhances bone regeneration. J. Control. Release 2010, 143, 45-52. [CrossRef]

52. Rampino, A.; Borgogna, M.; Blasi, P.; Bellich, B.; Cesàro, A. Chitosan nanoparticles: Preparation, size evolution and stability. Int. J. Pharm. 2013, 455, 219-228. [CrossRef]

53. Vedakumari, W.S.; Prabu, P.; Sastry, T.P. Chitosan-fibrin nanocomposites as drug delivering and wound healing materials. J. Biomed. Nanotechnol. 2015, 11, 657-667. [CrossRef] 
54. Shim, K.; Won, H.S.; Sang, Y.L.; Sang, H.L.; Seong, J.H.; Myung, C.L.; Lee, S.J. Chitosan nano-/microfibrous double-layered membrane with rolled-up three-dimensional structures for chondrocyte cultivation. J. Biomed. Mater. Res. Part A 2009, 90, 595-602. [CrossRef]

55. Poth, N.; Seiffart, V.; Gross, G.; Menzel, H.; Dempwolf, W. Biodegradable chitosan nanoparticle coatings on titanium for the delivery of BMP-2. Biomolecules 2015, 5, 3-19. [CrossRef]

56. Nagarajan, U.; Kawakami, K.; Zhang, S.; Chandrasekaran, B. Fabrication of solid collagen nanoparticles using electrospray deposition. Chem. Pharm. Bull. 2014, 62, 422-428. [CrossRef] [PubMed]

57. Liu, Y.; Lu, Y.; Tian, X.; Cui, G.; Zhao, Y.; Yang, Q.; Yu, S.; Xing, G.; Zhang, B. Segmental bone regeneration using an rhBMP-2-loaded gelatin/nanohydroxyapatite/fibrin scaffold in a rabbit model. Biomaterials 2009, 30, 6276-6285. [CrossRef] [PubMed]

58. Jahanshahi, M.; Sanati, M.H.; Hajizadeh, S.; Babaei, Z. Gelatin nanoparticle fabrication and optimization of the particle size. Phys. Status Solidi 2008, 205, 2898-2902. [CrossRef]

59. Miller, D.C.; Thapa, A.; Haberstroh, K.M.; Webster, T.J. Endothelial and vascular smooth muscle cell function on poly(lactic-co-glycolic acid) with nano-structured surface features. Biomaterials 2004, 25, 53-61. [CrossRef]

60. Danhier, F.; Ansorena, E.; Silva, J.M.; Coco, R.; Le Breton, A.; Préat, V. PLGA-based nanoparticles: An overview of biomedical applications. J. Control. Release 2012, 161, 505-522. [CrossRef]

61. Pattison, M.A.; Wurster, S.; Webster, T.J.; Haberstroh, K.M. Three-dimensional, nano-structured PLGA scaffolds for bladder tissue replacement applications. Biomaterials 2005, 26, 2491-2500. [CrossRef]

62. Soundrapandian, C.; Mahato, A.; Kundu, B.; Datta, S.; Sa, B.; Basu, D. Development and effect of different bioactive silicate glass scaffolds: In vitro evaluation for use as a bone drug delivery system. J. Mech. Behav. Biomed. Mater. 2014, 40, 1-12. [CrossRef] [PubMed]

63. Baldrighi, M.; Trusel, M.; Tonini, R.; Giordani, S. Carbon Nanomaterials Interfacing with Neurons: An In vivo Perspective. Front. Neurosci. 2016, 10, 250. [CrossRef] [PubMed]

64. Gorain, B.; Choudhury, H.; Pandey, M.; Kesharwani, P.; Abeer, M.M.; Tekade, R.K.; Hussain, Z. Carbon nanotube scaffolds as emerging nanoplatform for myocardial tissue regeneration: A review of recent developments and therapeutic implications. Biomed. Pharmacother. 2018, 104, 496-508. [CrossRef] [PubMed]

65. Zhu, Z. An overview of carbon nanotubes and graphene for biosensing applications. Nanomicro Lett. 2017, 9, 25. [CrossRef]

66. Guo, Q.; Shen, X.; Li, Y.; Xu, S. Carbon nanotubes-based drug delivery to cancer and brain. Curr. Med. Sci. 2017, 37, 635-641. [CrossRef] [PubMed]

67. Fahy, E.; Subramaniam, S.; Murphy, R.C.; Nishijima, M.; Raetz, C.R.H.; Shimizu, T.; Spener, F.; van Meer, G.; Wakelam, M.J.O.; Dennis, E.A. Update of the LIPID MAPS comprehensive classification system for lipids. J. Lipid Res. 2009, 50, S9-S14. [CrossRef] [PubMed]

68. Vemuri, S.; Rhodes, C.T. Preparation and characterization of liposomes as therapeutic delivery systems: A review. Pharm. Acta Helv. 1995, 70, 95-111. [CrossRef]

69. Subramaniam, S.; Fahy, E.; Gupta, S.; Sud, M.; Byrnes, R.W.; Cotter, D.; Dinasarapu, A.R.; Maurya, M.R. Bioinformatics and systems biology of the lipidome. Chem. Rev. 2011, 111, 6452-6490. [CrossRef]

70. Khan, I.; Saeed, K.; Khan, I. Nanoparticles: Properties, applications and toxicities. Arab. J. Chem. 2019, 12, 908-931. [CrossRef]

71. Carbone, C.; Leonardi, A.; Cupri, S.; Puglisi, G.; Pignatello, R. Pharmaceutical and biomedical applications of lipid-based nanocarriers. Pharm. Pat. Anal. 2014, 3, 199-215. [CrossRef]

72. Bozzuto, G.; Molinari, A. Liposomes as nanomedical devices. Int. J. Nanomed. 2015, 10, 975-999. [CrossRef]

73. Puri, A.; Loomis, K.; Smith, B.; Lee, J.-H.; Yavlovich, A.; Heldman, E.; Blumenthal, R. Lipid-based nanoparticles as pharmaceutical drug carriers: From concepts to clinic. Crit. Rev. Ther. Drug Carr. Syst. 2009, 26, 523-580. [CrossRef]

74. Rai, R.; Alwani, S.; Badea, I. Polymeric nanoparticles in gene therapy: New avenues of design and optimization for delivery applications. Polymers 2019, 11, 745. [CrossRef]

75. Dolatabadi, J.E.N.; Omidi, Y. Solid lipid-based nanocarriers as efficient targeted drug and gene delivery systems. TrAC Trends Anal. Chem. 2016, 77, 100-108. [CrossRef]

76. Mukherjee, S.; Ray, S.; Thakur, R.S. Solid lipid nanoparticles: A modern formulation approach in drug delivery system. Indian J. Pharm. Sci. 2009, 71, 349-358. [CrossRef] [PubMed] 
77. Tamjidi, F.; Shahedi, M.; Varshosaz, J.; Nasirpour, A. Nanostructured lipid carriers (NLC): A potential delivery system for bioactive food molecules. Innov. Food Sci. Emerg. Technol. 2013, 19, 29-43. [CrossRef]

78. Mouzouvi, C.R.A.; Umerska, A.; Bigot, A.K.; Saulnier, P. Surface active properties of lipid nanocapsules. PLoS ONE 2017, 12, e0179211. [CrossRef] [PubMed]

79. Irby, D.; Du, C.; Li, F. Lipid—Drug conjugate for enhancing drug delivery. Mol. Pharm. 2017, 14, 1325-1338. [CrossRef]

80. Talegaonkar, S.; Bhattacharyya, A. Potential of lipid nanoparticles (SLNs and NLCs) in enhancing oral bioavailability of drugs with poor intestinal permeability. AAPS PharmSciTech 2019, 20, 121. [CrossRef]

81. Dave, V.; Tak, K.; Sohgaura, A.; Gupta, A.; Sadhu, V.; Reddy, K.R. Lipid-polymer hybrid nanoparticles: Synthesis strategies and biomedical applications. J. Microbiol. Methods 2019, 160, 130-142. [CrossRef]

82. Bangham, A.D.; Standish, M.M.; Watkins, J.C. Diffusion of univalent ions across the lamellae of swollen phospholipids. J. Mol. Biol. 1965, 13, 238-IN27. [CrossRef]

83. Akbarzadeh, A.; Rezaei-Sadabady, R.; Davaran, S.; Joo, S.; Zarghami, N.; Hanifehpour, Y.; Samiei, M.; Kouhi, M.; Nejati, K. Liposome: Classification, preparation, and applications. Nanoscale Res. Lett. 2013, 8, 102. [CrossRef]

84. Daraee, H.; Etemadi, A.; Kouhi, M.; Alimirzalu, S.; Akbarzadeh, A. Application of liposomes in medicine and drug delivery. Artif. Cells Nanomed. Biotechnol. 2016, 44, 381-391. [CrossRef]

85. Fenske, D.B.; Chonn, A.; Cullis, P.R. Liposomal nanomedicines: An emerging field. Toxicol. Pathol. 2008, 36, 21-29. [CrossRef]

86. Immordino, M.L.; Dosio, F.; Cattel, L. Stealth liposomes: Review of the basic science, rationale, and clinical applications, existing and potential. Int. J. Nanomed. 2006, 1, 297-315.

87. La, W.-G.; Jin, M.; Park, S.; Yoon, H.-H.; Jeong, G.-J.; Bhang, S.; Park, H.; Char, K.; Kim, B.-S. Delivery of bone morphogenetic protein-2 and substance P using graphene oxide for bone regeneration. Int. J. Nanomed. 2014, 9 (Suppl. 1), 107-116.

88. Du, G.-Y.; He, S.-W.; Sun, C.-X.; Mi, L.-D. Bone morphogenic Protein-2 (rhBMP2)-loaded silk fibroin scaffolds to enhance the osteoinductivity in bone tissue engineering. Nanoscale Res. Lett. 2017, 12, 573. [CrossRef] [PubMed]

89. Takahashi, M.; Inafuku, K.; Miyagi, T.; Oku, H.; Wada, K.; Imura, T.; Kitamoto, D. Efficient preparation of liposomes encapsulating food materials using lecithins by a mechanochemical method. J. Oleo Sci. 2007, 56, 35-42. [CrossRef]

90. Zhu, C.T.; Xu, Y.Q.; Shi, J.; Li, J.; Ding, J. Liposome combined porous $\beta$-TCP scaffold: Preparation, characterization, and anti-biofilm activity. Drug Deliv. 2010, 17, 391-398. [CrossRef]

91. Li, Y.; Bai, Y.; Pan, J.; Wang, H.; Li, H.; Xu, X.; Fu, X.; Shi, R.; Luo, Z.; Li, Y.; et al. A hybrid 3D-printed aspirin-laden liposome composite scaffold for bone tissue engineering. J. Mater. Chem. B 2019, 7, 619-629. [CrossRef]

92. Sou, K.; Inenaga, S.; Takeoka, S.; Tsuchida, E. Loading of curcumin into macrophages using lipid-based nanoparticles. Int. J. Pharm. 2008, 352, 287-293. [CrossRef]

93. Mayer, L.D.; Bally, M.B.; Cullis, P.R. Uptake of adriamycin into large unilamellar vesicles in response to a $\mathrm{pH}$ gradient. Biochim. Biophys. Acta Biomembr. 1986, 857, 123-126. [CrossRef]

94. Cullis, P.R.; Hope, M.J.; Bally, M.B.; Madden, T.D.; Mayer, L.D.; Fenske, D.B. Influence of pH gradients on the transbilayer transport of drugs, lipids, peptides and metal ions into large unilamellar vesicles. Biochim. Biophys. Acta Rev. Biomembr. 1997, 1331, 187-211. [CrossRef]

95. Dang, M.; Saunders, L.; Niu, X.; Fan, Y.; Ma, P.X. Biomimetic delivery of signals for bone tissue engineering. Bone Res. 2018, 6, 25. [CrossRef]

96. Kulkarni, M.; Greiser, U.; O’Brien, T.; Pandit, A. Liposomal gene delivery mediated by tissue-engineered scaffolds. Trends Biotechnol. 2010, 28, 28-36. [CrossRef] [PubMed]

97. Abbasi, E.; Aval, S.F.; Akbarzadeh, A.; Milani, M.; Nasrabadi, H.T.; Joo, S.W.; Hanifehpour, Y.; Nejati-Koshki, K.; Pashaei-Asl, R. Dendrimers: Synthesis, applications, and properties. Nanoscale Res. Lett. 2014, 9, 247. [CrossRef] [PubMed]

98. Majoral, J.-P.; Caminade, A.-M. Dendrimers containing heteroatoms (Si, P, B, Ge, or Bi). Chem. Rev. 1999, 99, 845-880. [CrossRef] [PubMed]

99. Bosman, A.W.; Janssen, H.M.; Meijer, E.W. About dendrimers: Structure, physical properties, and applications. Chem. Rev. 1999, 99, 1665-1688. [CrossRef] [PubMed] 
100. Joshi, N.; Grinstaff, M. Applications of dendrimers in tissue engineering. Curr. Top. Med. Chem. 2008, 8, 1225-1236. [CrossRef] [PubMed]

101. Barrett, T.; Ravizzini, G.; Choyke, P.L.; Kobayashi, H. Dendrimers in medical nanotechnology. IEEE Eng. Med. Biol. Mag. 2009, 28, 12-22. [CrossRef] [PubMed]

102. Liu, Y.; Tee, J.K.T.; Chiu, G.N.C. Dendrimers in oral drug delivery application: Current explorations, toxicity issues and strategies for improvement. Curr. Pharm. Des. 2015, 21, 2629-2642. [CrossRef] [PubMed]

103. Courtenay, J.C.; Deneke, C.; Lanzoni, E.M.; Costa, C.A.; Bae, Y.; Scott, J.L.; Sharma, R.I. Modulating cell response on cellulose surfaces; tunable attachment and scaffold mechanics. Cellulose 2018, 25, 925-940. [CrossRef]

104. Zhou, L.; Shan, Y.; Hu, H.; Yu, B.Y.; Cong, H. Synthesis and biomedical applications of dendrimers. Curr. Org. Chem. 2018, 22, 600-612. [CrossRef]

105. Opina, A.C.; Wong, K.J.; Griffiths, G.L.; Turkbey, B.I.; Bernardo, M.; Nakajima, T.; Kobayashi, H.; Choyke, P.L.; Vasalatiy, O. Preparation and long-term biodistribution studies of a PAMAM dendrimer G5-Gd-BnDOTA conjugate for lymphatic imaging. Nanomedicine 2014, 10, 1423-1437. [CrossRef]

106. Shadrack, D.M.; Swai, H.S.; Munissi, J.J.E.; Mubofu, E.B.; Nyandoro, S.S. Polyamidoamine dendrimers for enhanced solubility of small molecules and other desirable properties for site specific delivery: Insights from experimental and computational studies. Molecules 2018, 23, 1419. [CrossRef] [PubMed]

107. Din, F.U.; Aman, W.; Ullah, I.; Qureshi, O.S.; Mustapha, O.; Shafique, S.; Zeb, A. Effective use of nanocarriers as drug delivery systems for the treatment of selected tumors. Int. J. Nanomed. 2017, 12, 7291-7309. [CrossRef] [PubMed]

108. Pooja, D.; Sistla, R.; Kulhari, H. Chapter 7-Dendrimer-drug conjugates: Synthesis strategies, stability and application in anticancer drug delivery. In Design of Nanostructures for Theranostics Applications; Grumezescu, A.M., Ed.; William Andrew Publishing: Norwich, NY, USA, 2018; pp. 277-303.

109. Yiyun, C.; Na, M.; Tongwen, X.; Rongqiang, F.; Xueyuan, W.; Xiaomin, W.; Longping, W. Transdermal delivery of nonsteroidal anti-inflammatory drugs mediated by polyamidoamine (PAMAM) dendrimers. J. Pharm. Sci. 2007, 96, 595-602. [CrossRef] [PubMed]

110. Fu, H.-L.; Cheng, S.-X.; Zhang, X.-Z.; Zhuo, R.-X. Dendrimer/DNA complexes encapsulated functional biodegradable polymer for substrate-mediated gene delivery. J. Gene Med. 2008, 10, 1334-1342. [CrossRef]

111. Grinstaff, M.W. Dendritic macromers for hydrogel formation: Tailored materials for ophthalmic, orthopedic, and biotech applications. J. Polym. Sci. Part A Polym. Chem. 2008, 46, 383-400. [CrossRef]

112. Grinstaff, M. Biodendrimers: New polymeric biomaterials for tissues engineering. Chem. A Eur. J. 2002, 8, 2838-2846. [CrossRef]

113. Boduch-Lee, K.A.; Chapman, T.; Petricca, S.E.; Marra, K.G.; Kumta, P. Design and synthesis of hydroxyapatite composites containing an mPEG-Dendritic Poly(l-lysine) star polycaprolactone. Macromolecules 2004, 37, 8959-8966. [CrossRef]

114. Rajzer, I. Fabrication of bioactive polycaprolactone/hydroxyapatite scaffolds with final bilayer nano-/micro-fibrous structures for tissue engineering application. J. Mater. Sci. 2014, 49, 5799-5807. [CrossRef]

115. Mintzer, M.A.; Grinstaff, M.W. Biomedical applications of dendrimers: A tutorial. Chem. Soc. Rev. 2011, 40, 173-190. [CrossRef]

116. Oliveira, J.M.; Sousa, R.A.; Kotobuki, N.; Tadokoro, M.; Hirose, M.; Mano, J.F.; Reis, R.L.; Ohgushi, H. The osteogenic differentiation of rat bone marrow stromal cells cultured with dexamethasone-loaded carboxymethylchitosan/poly(amidoamine) dendrimer nanoparticles. Biomaterials 2009, 30, 804-813. [CrossRef]

117. Fathi-Achachelouei, M.; Knopf-Marques, H.; Ribeiro da Silva, C.E.; Barthès, J.; Bat, E.; Tezcaner, A.; Vrana, N.E. Use of nanoparticles in tissue engineering and regenerative medicine. Front. Bioeng. Biotechnol. 2019, 7, 113. [CrossRef] [PubMed]

118. Jain, S.K. PEGylation: An approach for drug delivery. A review. Crit. Rev. Ther. Drug Carr. Syst. 2008, 25, 403-447. [CrossRef]

119. Yoo, H.S.; Kim, T.G.; Park, T.G. Surface-functionalized electrospun nanofibers for tissue engineering and drug delivery. Adv. Drug Deliv. Rev. 2009, 61, 1033-1042. [CrossRef] [PubMed]

120. Rao, J.P.; Geckeler, K.E. Polymer nanoparticles: Preparation techniques and size-control parameters. Prog. Polym. Sci. 2011, 36, 887-913. [CrossRef] 
121. Santo, V.E.; Ratanavaraporn, J.; Sato, K.; Gomes, M.E.; Mano, J.F.; Reis, R.L.; Tabata, Y. Cell engineering by the internalization of bioinstructive micelles for enhanced bone regeneration. Nanomedicine 2015, 10, 1707-1721. [CrossRef] [PubMed]

122. Nicolas, J.; Mura, S.; Brambilla, D.; Mackiewicz, N.; Couvreur, P. Design, functionalization strategies and biomedical applications of targeted biodegradable/biocompatible polymer-based nanocarriers for drug delivery. Chem. Soc. Rev. 2013, 42, 1147-1235. [CrossRef]

123. Fàbregas, A.; Miñarro, M.; García-Montoya, E.; Pérez-Lozano, P.; Carrillo, C.; Sarrate, R.; Sánchez, N.; Ticó, J.R.; Suñé-Negre, J.M. Impact of physical parameters on particle size and reaction yield when using the ionic gelation method to obtain cationic polymeric chitosan-tripolyphosphate nanoparticles. Int. J. Pharm. 2013, 446, 199-204. [CrossRef]

124. Vaculikova, E.; Grunwaldova, V.; Kral, V.; Dohnal, J.; Jampilek, J. Preparation of candesartan and atorvastatin nanoparticles by solvent evaporation. Molecules 2012, 17, 13221-13234. [CrossRef]

125. Chung, J.W.; Lee, K.; Neikirk, C.; Nelson, C.M.; Priestley, R.D. Photoresponsive coumarin-stabilized polymeric nanoparticles as a detectable drug carrier. Small 2012, 8, 1693-1700. [CrossRef]

126. Langer, K.; Anhorn, M.G.; Steinhauser, I.; Dreis, S.; Celebi, D.; Schrickel, N.; Faust, S.; Vogel, V. Human serum albumin (HSA) nanoparticles: Reproducibility of preparation process and kinetics of enzymatic degradation. Int. J. Pharm. 2008, 347, 109-117. [CrossRef]

127. Yu, X.; Trase, I.; Ren, M.; Duval, K.; Guo, X.; Chen, Z. Design of nanoparticle-based carriers for targeted drug delivery. J. Nanomater. 2016, 2016, 1087250. [CrossRef] [PubMed]

128. Nagavarma, B.V.N.; Yadav, H.K.S.; Ayaz, A.; Vasudha, L.S.; Shivakumar, H.G. Different techniques for preparation of polymeric nanoparticles-A review. Asian J. Pharm. Clin. Res. 2012, 5, 16-23.

129. Calzoni, E.; Cesaretti, A.; Polchi, A.; Di Michele, A.; Tancini, B.; Emiliani, C. Biocompatible polymer nanoparticles for drug delivery applications in cancer and neurodegenerative disorder therapies. J. Funct. Biomater. 2019, 10, 4. [CrossRef] [PubMed]

130. Joye, I.J.; McClements, D.J. Biopolymer-based nanoparticles and microparticles: Fabrication, characterization, and application. Curr. Opin. Colloid Interface Sci. 2014, 19, 417-427. [CrossRef]

131. Ezhilarasi, P.N.; Karthik, P.; Chhanwal, N.; Anandharamakrishnan, C. Nanoencapsulation techniques for food bioactive components: A review. Food Bioprocess Technol. 2013, 6, 628-647. [CrossRef]

132. Bennet, D.; Kim, S. Polymer nanoparticles for smart drug delivery. In Application of Nanotechnology in Drug Delivery; Sezer, A.D., Ed.; IntechOpen: Rijeka, Croatia, 2014.

133. Makadia, H.K.; Siegel, S.J. Poly Lactic-co-glycolic acid (PLGA) as biodegradable controlled drug delivery carrier. Polymers 2011, 3, 1377-1397. [CrossRef]

134. Shoichet, M.S. Polymer scaffolds for biomaterials applications. Macromolecules 2010, 43, 581-591. [CrossRef]

135. Priya James, H.; John, R.; Alex, A.; Anoop, K.R. Smart polymers for the controlled delivery of drugs-A concise overview. Acta Pharm. Sin. B 2014, 4, 120-127. [CrossRef]

136. Kashirina, A.; Yao, Y.; Liu, Y.; Leng, J. Biopolymers as bone substitutes: A review. Biomater. Sci. 2019, 7, 3961-3983. [CrossRef] [PubMed]

137. Van Vlierberghe, S.; Dubruel, P.; Schacht, E. Biopolymer-based hydrogels as scaffolds for tissue engineering applications: A review. Biomacromolecules 2011, 12, 1387-1408. [CrossRef] [PubMed]

138. Tang, Z.; He, C.; Tian, H.; Ding, J.; Hsiao, B.S.; Chu, B.; Chen, X. Polymeric nanostructured materials for biomedical applications. Prog. Polym. Sci. 2016, 60, 86-128. [CrossRef]

139. Cheng, R.; Meng, F.; Deng, C.; Klok, H.-A.; Zhong, Z. Dual and multi-stimuli responsive polymeric nanoparticles for programmed site-specific drug delivery. Biomaterials 2013, 34, 3647-3657. [CrossRef] [PubMed]

140. Wu, S.; Liu, X.; Yeung, K.W.K.; Liu, C.; Yang, X. Biomimetic porous scaffolds for bone tissue engineering. Mater. Sci. Eng. R Rep. 2014, 80, 1-36. [CrossRef]

141. Sharma, K.; Mujawar, M.A.; Kaushik, A. State-of-art functional biomaterials for tissue engineering. Front. Mater. 2019, 6, 1-10. [CrossRef]

142. Tezcaner, A.; Baran, E.; Keskin, D. Nanoparticles based on plasma proteins for drug delivery applications. Curr. Pharm. Des. 2016, 22, 3445-3454. [CrossRef]

143. Kumar, P.; Dehiya, B.S.; Sindhu, A. Comparative study of chitosan and chitosan-gelatin scaffold for tissue engineering. Int. Nano Lett. 2017, 7, 285-290. [CrossRef] 
144. Younes, I.; Rinaudo, M. Chitin and chitosan preparation from marine sources. Structure, properties and applications. Mar. Drugs 2015, 13, 1133-1174. [CrossRef]

145. Al-Qadi, S.; Grenha, A.; Carrión-Recio, D.; Seijo, B.; Remuñán-López, C. Microencapsulated chitosan nanoparticles for pulmonary protein delivery: In vivo evaluation of insulin-loaded formulations. J. Control. Release 2012, 157, 383-390. [CrossRef]

146. Berger, J.; Reist, M.; Mayer, J.M.; Felt, O.; Peppas, N.A.; Gurny, R. Structure and interactions in covalently and ionically crosslinked chitosan hydrogels for biomedical applications. Eur. J. Pharm. Biopharm. 2004, 57, 19-34. [CrossRef]

147. Agnihotri, S.A.; Mallikarjuna, N.N.; Aminabhavi, T.M. Recent advances on chitosan-based micro- and nanoparticles in drug delivery. J. Control. Release 2004, 100, 5-28. [CrossRef]

148. Kim, S.K.; Rajapakse, N. Enzymatic production and biological activities of chitosan oligosaccharides (COS): A review. Carbohydr. Polym. 2005, 62, 357-368. [CrossRef]

149. Campos, E.V.R.; Oliveira, J.L.; Fraceto, L.F. Poly(ethylene glycol) and cyclodextrin-grafted chitosan: From methodologies to preparation and potential biotechnological applications. Front. Chem. 2017, 5, 93. [CrossRef]

150. Wang, J.J.; Zeng, Z.W.; Xiao, R.Z.; Xie, T.; Zhou, G.L.; Zhan, X.R.; Wang, S.L. Recent advances of chitosan nanoparticles as drug carriers. Int. J. Nanomed. 2011, 6, 765-774.

151. Levengood, S.L.; Zhang, M. Chitosan-based scaffolds for bone tissue engineering. J. Mater. Chem. B 2014, 2, 3161-3184. [CrossRef]

152. Eap, S.; Keller, L.; Schiavi, J.; Huck, O.; Jacomine, L.; Fioretti, F.; Gauthier, C.; Sebastian, V.; Schwinté, P.; Benkirane-Jessel, N. A living thick nanofibrous implant bifunctionalized with active growth factor and stem cells for bone regeneration. Int. J. Nanomed. 2015, 10, 1061-1075.

153. Shrestha, A.; Kishen, A. The effect of tissue inhibitors on the antibacterial activity of chitosan nanoparticles and photodynamic therapy. J. Endod. 2012, 38, 1275-1278. [CrossRef]

154. Kumar, P.; Dehiya, B.S.; Sindhu, A. Synthesis and characterization of nHA-PEG and nBG-PEG scaffolds for hard tissue engineering applications. Ceram. Int. 2019, 45, 8370-8379. [CrossRef]

155. Kumar, P.; Saini, M.; Dehiya, B.S.; Umar, A.; Sindhu, A.; Mohammed, H.; Al-Hadeethi, Y.; Guo, Z. Fabrication and in-vitro biocompatibility of freeze-dried CTS-nHA and CTS-nBG scaffolds for bone regeneration applications. Int. J. Biol. Macromol. 2020, 149, 1-10. [CrossRef]

156. Bhowmick, A.; Banerjee, S.L.; Pramanik, N.; Jana, P.; Mitra, T.; Gnanamani, A.; Das, M.; Kundu, P.P. Organically modified clay supported chitosan/hydroxyapatite-zinc oxide nanocomposites with enhanced mechanical and biological properties for the application in bone tissue engineering. Int. J. Biol. Macromol. 2018, 106, 11-19. [CrossRef]

157. Yilgor, P.; Tuzlakoglu, K.; Reis, R.L.; Hasirci, N.; Hasirci, V. Incorporation of a sequential BMP-2/BMP-7 delivery system into chitosan-based scaffolds for bone tissue engineering. Biomaterials 2009, 30, 3551-3559. [CrossRef]

158. Mili, B.; Das, K.; Kumar, A.; Saxena, A.C.; Singh, P.; Ghosh, S.; Bag, S. Preparation of NGF encapsulated chitosan nanoparticles and its evaluation on neuronal differentiation potentiality of canine mesenchymal stem cells. J. Mater. Sci. Mater. Med. 2017, 29, 4. [CrossRef]

159. Kumar, $\mathrm{P}$. Nano-TiO(2) doped chitosan scaffold for the bone tissue engineering applications. Int. J. Biomater. 2018, 2018, 6576157. [CrossRef]

160. Koosha, M.; Solouk, A.; Ghalei, S.; Sadeghi, D.; Bagheri, S.; Mirzadeh, H. Electrospun chitosan/gum tragacanth/polyvinyl alcohol hybrid nanofibrous scaffold for tissue engineering applications. Bioinspired Biomim. Nanobiomater. 2019, 9, 1-8.

161. Zugravu, M.; Smith, R.; Reves, B.; Jennings, J.; Cooper, J.; Haggard, W.; Bumgardner, J. Physical properties and in vitro evaluation of collagen-chitosan-calcium phosphate microparticle-based scaffolds for bone tissue regeneration. J. Biomater. Appl. 2012, 28, 566-579. [CrossRef] [PubMed]

162. Wahl, D.; Czernuszka, J. Collagen-hydroxyapatite composites for hard tissue repair. Eur. Cell Mater. 2006, 11, 43-56. [CrossRef] [PubMed]

163. Krafts, K.P. Tissue repair: The hidden drama. Organogenesis 2010, 6, 225-233. [CrossRef]

164. Dong, C.; Lv, Y. Application of collagen scaffold in tissue engineering: Recent advances and new perspectives. Polymers 2016, 8, 42. [CrossRef] [PubMed] 
165. Lim, Y.-S.; Ok, Y.-J.; Hwang, S.-Y.; Kwak, J.-Y.; Yoon, S. Marine collagen as a promising biomaterial for biomedical applications. Mar. Drugs 2019, 17, 467. [CrossRef]

166. Khan, R.; Khan, M.H. Use of collagen as a biomaterial: An update. J. Indian Soc. Periodontol. 2013, 17, 539-542. [CrossRef]

167. D’Mello, S.; Atluri, K.; Geary, S.M.; Hong, L.; Elangovan, S.; Salem, A.K. Bone regeneration using gene-activated matrices. AAPS J. 2017, 19, 43-53. [CrossRef]

168. Fujioka-Kobayashi, M.; Schaller, B.; Saulacic, N.; Pippenger, B.E.; Zhang, Y.; Miron, R.J. Absorbable collagen sponges loaded with recombinant bone morphogenetic protein 9 induces greater osteoblast differentiation when compared to bone morphogenetic protein 2. Clin. Exp. Dent. Res. 2017, 3, 32-40. [CrossRef] [PubMed]

169. Nakagawa, T.; Tagawa, T. Ultrastructural study of direct bone formation induced by BMPs-collagen complex implanted into an ectopic site. Oral Dis. 2000, 6, 172-179. [CrossRef] [PubMed]

170. Xie, J.; Baumann, M.J.; McCabe, L.R. Osteoblasts respond to hydroxyapatite surfaces with immediate changes in gene expression. J. Biomed. Mater. Res. Part A 2004, 71, 108-117. [CrossRef] [PubMed]

171. Chan, E.C.; Kuo, S.-M.; Kong, A.M.; Morrison, W.A.; Dusting, G.J.; Mitchell, G.M.; Lim, S.Y.; Liu, G.-S. Three dimensional collagen scaffold promotes intrinsic vascularisation for tissue engineering applications. PLoS ONE 2016, 11, e0149799. [CrossRef]

172. Vázquez, J.J.; Martín-Martínez, E.S. Collagen and elastin scaffold by electrospinning for skin tissue engineering applications. J. Mater. Res. 2019, 34, 2819-2827. [CrossRef]

173. Marques, C.F.; Diogo, G.S.; Pina, S.; Oliveira, J.M.; Silva, T.H.; Reis, R.L. Collagen-based bioinks for hard tissue engineering applications: A comprehensive review. J. Mater. Sci. Mater. Med. 2019, 30, 32. [CrossRef]

174. Hoque, M.E.; Hutmacher, D.W.; Feng, W.; Li, S.; Huang, M.-H.; Vert, M.; Wong, Y.S. Fabrication using a rapid prototyping system and in vitro characterization of PEG-PCL-PLA scaffolds for tissue engineering. J. Biomater. Sci. Polym. Ed. 2005, 16, 1595-1610. [CrossRef]

175. Ba Linh, N.T.; Lee, K.H.; Lee, B.T. Functional nanofiber mat of polyvinyl alcohol/gelatin containing nanoparticles of biphasic calcium phosphate for bone regeneration in rat calvaria defects. J. Biomed. Mater. Res. Part A 2013, 101, 2412-2423. [CrossRef]

176. Elzoghby, A.O. Gelatin-based nanoparticles as drug and gene delivery systems: Reviewing three decades of research. J. Control. Release 2013, 172, 1075-1091. [CrossRef]

177. Santoro, M.; Tatara, A.M.; Mikos, A.G. Gelatin carriers for drug and cell delivery in tissue engineering. J. Control. Release 2014, 190, 210-218. [CrossRef]

178. Won, Y.-W.; Yoon, S.-M.; Sonn, C.H.; Lee, K.-M.; Kim, Y.-H. Nano self-assembly of recombinant human gelatin conjugated with $\alpha$-tocopheryl succinate for hsp90 inhibitor, 17-AAG, delivery. ACS Nano 2011, 5, 3839-3848. [CrossRef] [PubMed]

179. Olsen, D.; Yang, C.; Bodo, M.; Chang, R.; Leigh, S.; Baez, J.; Carmichael, D.; Perälä, M.; Hämäläinen, E.-R.; Jarvinen, M.; et al. Recombinant collagen and gelatin for drug delivery. Adv. Drug Deliv. Rev. 2003, 55, 1547-1567. [CrossRef] [PubMed]

180. Su, K.; Wang, C. Recent advances in the use of gelatin in biomedical research. Biotechnol. Lett. 2015, 37, 2139-2145. [CrossRef] [PubMed]

181. Nitta, S.K.; Numata, K. Biopolymer-Based nanoparticles for drug/gene delivery and tissue engineering. Int. J. Mol. Sci. 2013, 14, 1629-1654. [CrossRef]

182. Kuijpers, A.J.; Engbers, G.H.M.; Krijgsveld, J.; Zaat, S.A.J.; Dankert, J.; Feijen, J. Cross-linking and characterisation of gelatin matrices for biomedical applications. J. Biomater. Sci. Polym. Ed. 2000, 11, 225-243. [CrossRef]

183. Bigi, A.; Cojazzi, G.; Panzavolta, S.; Rubini, K.; Roveri, N. Mechanical and thermal properties of gelatin films at different degrees of glutaraldehyde crosslinking. Biomaterials 2001, 22, 763-768. [CrossRef]

184. Yue, K.; Trujillo-de Santiago, G.; Alvarez, M.M.; Tamayol, A.; Annabi, N.; Khademhosseini, A. Synthesis, properties, and biomedical applications of gelatin methacryloyl (GelMA) hydrogels. Biomaterials 2015, 73, 254-271. [CrossRef]

185. Wang, H.; Boerman, O.; Sariibrahimoglu, K.; Li, Y.; Jansen, J.; Leeuwenburgh, S. Comparison of micro- vs. nanostructured colloidal gelatin gels for sustained delivery of osteogenic proteins: Bone morphogenetic protein-2 and alkaline phosphatase. Biomaterials 2012, 33, 8695-8703. [CrossRef] 
186. Perez, R.; del Valle, S.; Altankov, G.; Ginebra, M.-P. Porous hydroxyapatite and gelatin/hydroxyapatite microspheres obtained by calcium phosphate cement emulsion. J. Biomed. Mater. Res. Part B Appl. Biomater. 2011, 97, 156-166. [CrossRef]

187. Gil, E.S.; Frankowski, D.J.; Spontak, R.J.; Hudson, S.M. Swelling behavior and morphological evolution of mixed gelatin/silk fibroin hydrogels. Biomacromolecules 2005, 6, 3079-3087. [CrossRef]

188. Ulrich, D.; Edwards, S.; Su, K.; Tan, K.; White, J.; Ramshaw, J.; Lo, C.; Rosamilia, A.; Werkmeister, J.; Gargett, C. Human endometrial mesenchymal stem cells modulate the tissue response and mechanical behavior of polyamide mesh implants for pelvic organ prolapse repair. Tissue Eng. Part A 2013, 20, 785-798. [CrossRef]

189. Han, J.; Lazarovici, P.; Pomerantz, C.; Chen, X.; Wei, Y.; Lelkes, P.I. Co-Electrospun blends of PLGA, gelatin, and elastin as potential nonthrombogenic scaffolds for vascular tissue engineering. Biomacromolecules 2011, 12, 399-408. [CrossRef] [PubMed]

190. Ovsianikov, A.; Deiwick, A.; van Vlierberghe, S.; Dubruel, P.; Möller, L.; Dräger, G.; Chichkov, B. Laser fabrication of three-dimensional CAD scaffolds from photosensitive gelatin for applications in tissue engineering. Biomacromolecules 2011, 12, 851-858. [CrossRef] [PubMed]

191. Tielens, S.; Declercq, H.; Gorski, T.; Lippens, E.; Schacht, E.; Cornelissen, M. Gelatin-based microcarriers as embryonic stem cell delivery system in bone tissue engineering: An in-vitro study. Biomacromolecules 2007, 8 , 825-832. [CrossRef] [PubMed]

192. Samal, S.K.; Goranov, V.; Dash, M.; Russo, A.; Shelyakova, T.; Graziosi, P.; Lungaro, L.; Riminucci, A.; Uhlarz, M.; Bañobre-López, M.; et al. Multilayered magnetic gelatin membrane scaffolds. ACS Appl. Mater. Interfaces 2015, 7, 23098-23109. [CrossRef] [PubMed]

193. Gentile, P.; Chiono, V.; Carmagnola, I.; Hatton, P.V. An overview of poly(lactic-co-glycolic) acid (PLGA)-based biomaterials for bone tissue engineering. Int. J. Mol. Sci. 2014, 15, 3640-3659. [CrossRef] [PubMed]

194. Meretoja, V.V.; Tirri, T.; Malin, M.; Seppälä, J.V.; Närhi, T.O. Ectopic bone formation in and soft-tissue response to P(CL/DLLA)/bioactive glass composite scaffolds. Clin. Oral Implants Res. 2014, 25, 159-164. [CrossRef]

195. Yang, K.; Wan, J.; Zhang, S.; Zhang, Y.; Lee, S.-T.; Liu, Z. In vivo pharmacokinetics, long-term biodistribution, and toxicology of PEGylated graphene in mice. ACS Nano 2011, 5, 516-522. [CrossRef] [PubMed]

196. Zhang, J.; Zhao, S.; Zhu, Y.; Huang, Y.; Zhu, M.; Tao, C.; Zhang, C. Three-dimensional printing of strontium-containing mesoporous bioactive glass scaffolds for bone regeneration. Acta Biomater. 2014, 10, 2269-2281. [CrossRef]

197. Padmanabhan, J.; Kyriakides, T.R. Nanomaterials, inflammation, and tissue engineering. Wiley Interdiscip. Rev. Nanomed. Nanobiotechnol. 2015, 7, 355-370. [CrossRef]

198. Lombardo, D.; Kiselev, M.A.; Caccamo, M.T. Smart nanoparticles for drug delivery application: Development of versatile nanocarrier platforms in biotechnology and nanomedicine. J. Nanomater. 2019, 2019, 3702518. [CrossRef]

199. Harris, L.D.; Kim, B.; Mooney, D.J. Open pore biodegradable matrices formed with gas foaming. J. Biomed. Mater. Res. 1998, 42, 396-402. [CrossRef]

200. Mikos, A.G.; Thorsen, A.J.; Czerwonka, L.A.; Bao, Y.; Langer, R.; Winslow, D.N.; Vacanti, J.P. Preparation and characterization of poly(l-lactic acid) foams. Polymer 1994, 35, 1068-1077. [CrossRef]

201. Zein, I.; Hutmacher, D.W.; Tan, K.C.; Teoh, S.H. Fused deposition modeling of novel scaffold architectures for tissue engineering applications. Biomaterials 2002, 23, 1169-1185. [CrossRef]

202. Zhang, R.; Ma, P.X. Poly (A-hydroxyl acids)/hydroxyapatite porous composites for bone-tissue engineering.I. Preparation and morphology. J. Biomed. Mater. Res. 1999, 44, 446-455. [CrossRef]

203. Perkins, B.L.; Naderi, N. Carbon nanostructures in bone tissue engineering. Open Orthop. J. 2016, 10, 877-899. [CrossRef]

204. Dresselhaus, M.S.; Avouris, P. Introduction to carbon materials research. Carbon Nanotub. 2001, 9, 1-9.

205. Han, Z.J.; Rider, A.E.; Ishaq, M.; Kumar, S.; Kondyurin, A.; Bilek, M.M.M.; Levchenko, I.; Ostrikov, K. Carbon nanostructures for hard tissue engineering. RSC Adv. 2013, 3, 11058-11072. [CrossRef]

206. Eivazzadeh-Keihan, R.; Maleki, A.; de la Guardia, M.; Bani, M.S.; Chenab, K.K.; Pashazadeh-Panahi, P.; Baradaran, B.; Mokhtarzadeh, A.; Hamblin, M.R. Carbon based nanomaterials for tissue engineering of bone: Building new bone on small black scaffolds: A review. J. Adv. Res. 2019, 18, 185-201. [CrossRef]

207. Geetha Bai, R.; Muthoosamy, K.; Manickam, S.; Hilal-Alnaqbi, A. Graphene-based 3D scaffolds in tissue engineering: Fabrication, applications, and future scope in liver tissue engineering. Int. J. Nanomed. 2019, 14, 5753-5783. [CrossRef] 
208. Kim, H.; Macosko, C.W. Processing-property relationships of polycarbonate/graphene composites. Polymer 2009, 50, 3797-3809. [CrossRef]

209. Stankovich, S.; Dikin, D.A.; Dommett, G.H.B.; Kohlhaas, K.M.; Zimney, E.J.; Stach, E.A.; Piner, R.D.; Nguyen, S.B.T.; Ruoff, R.S. Graphene-based composite materials. Nature 2006, 442, 282-286. [CrossRef] [PubMed]

210. Bon, S.B.; Valentini, L.; Verdejo, R.; Fierro, J.L.G.; Peponi, L.; Lopez-Manchado, M.A.; Kenny, J.M. Plasma fluorination of chemically derived graphene sheets and subsequent modification with butylamine. Chem. Mater. 2009, 21, 3433-3438. [CrossRef]

211. Valentini, L.; Armentano, I.; Biagiotti, J.; Frulloni, E.; Kenny, J.M.; Santucci, S. Frequency dependent electrical transport between conjugated polymer and single-walled carbon nanotubes. Diam. Relat. Mater. 2003, 12, 1601-1609. [CrossRef]

212. MacDonald, R.A.; Voge, C.M.; Kariolis, M.; Stegemann, J.P. Carbon nanotubes increase the electrical conductivity of fibroblast-seeded collagen hydrogels. Acta Biomater. 2008, 4, 1583-1592. [CrossRef]

213. Armentano, I.; Dottori, M.; Fortunati, E.; Mattioli, S.; Kenny, J.M. Biodegradable polymer matrix nanocomposites for tissue engineering: A review. Polym. Degrad. Stabil. 2010, 95, 2126-2146. [CrossRef]

214. Armentano, I.; Fortunati, E.; Gigli, M.; Luzi, F.; Trotta, R.; Bicchi, I.; Soccio, M.; Lotti, N.; Munari, A.; Martino, S.; et al. Effect of SWCNT introduction in random copolymers on material properties and fibroblast long term culture stability. Polym. Degrad. Stab. 2016, 132, 220-230. [CrossRef]

215. Mihajlovic, M.; Mihajlovic, M.; Dankers, P.Y.W.; Masereeuw, R.; Sijbesma, R.P. Carbon nanotube reinforced supramolecular hydrogels for bioapplications. Macromol. Biosci. 2019, 19, 1800173. [CrossRef]

216. Wu, K.; Tao, J.; Qi, L.; Chen, S.; Wan, W. Intracellular microtubules as nano-scaffolding template self-assembles with conductive carbon nanotubes for biomedical device. Mater. Sci. Eng. C 2020, 113, 11971. [CrossRef]

217. Yang, Y.-L.; Ju, H.-Z.; Liu, S.-F.; Lee, T.-C.; Shih, Y.-W.; Chuang, L.-Y.; Guh, J.-Y.; Yang, Y.-Y.; Liao, T.-N.; Hung, T.-J.; et al. BMP-2 suppresses renal interstitial fibrosis by regulating epithelial-mesenchymal transition. J. Cell. Biochem. 2011, 112, 2558-2565. [CrossRef]

218. Minati, L.; Antonini, V.; Dalla Serra, M.; Speranza, G. Multifunctional branched gold-carbon nanotube hybrid for cell imaging and drug delivery. Langmuir 2012, 28, 15900-15906. [CrossRef]

219. Srikanth, M.; Asmatulu, R.; Cluff, K.; Yao, L. Material characterization and bioanalysis of hybrid scaffolds of carbon nanomaterial and polymer nanofibers. ACS Omega 2019, 4, 5044-5051. [CrossRef]

220. Singh, R.K.; Patel, K.D.; Kim, J.-J.; Kim, T.-H.; Kim, J.-H.; Shin, U.S.; Lee, E.-J.; Knowles, J.C.; Kim, H.-W. Multifunctional hybrid nanocarrier: Magnetic CNTs ensheathed with mesoporous silica for drug delivery and imaging system. ACS Appl. Mater. Interfaces 2014, 6, 2201-2208. [CrossRef]

221. Huang, W.; Zhang, J.; Dorn, H.C.; Geohegan, D.; Zhang, C. Assembly of single-walled carbon nanohorn supported liposome particles. Bioconjug. Chem. 2011, 22, 1012-1016. [CrossRef]

222. Chen, Q.; Zhu, C.; Thouas, G.A. Progress and challenges in biomaterials used for bone tissue engineering: Bioactive glasses and elastomeric composites. Prog. Biomater. 2012, 1, 2. [CrossRef]

223. Navarro, M.; Michiardi, A.; Castaño, O.; Planell, J.A. Biomaterials in orthopaedics. J. R. Soc. Interface 2008, 5 , 1137-1158. [CrossRef]

224. European Centre for Disease Prevention and Control: An Agency of the European Union. Available online: http://ecdc.europa.eu (accessed on 1 September 2020).

225. Wu, X.; Wu, M.; Zhao, J.X. Recent development of silica nanoparticles as delivery vectors for cancer imaging and therapy. Nanomed. Nanotechnol. Biol. Med. 2014, 10, 297-312. [CrossRef]

226. Rosenholm, J.M.; Zhang, J.; Linden, M.; Sahlgren, C. Mesoporous silica nanoparticles in tissue engineering-A perspective. Nanomedicine 2016, 11, 391-402. [CrossRef]

227. Bitar, A.; Ahmad, N.M.; Fessi, H.; Elaissari, A. Silica-based nanoparticles for biomedical applications. Drug Discov. Today 2012, 17, 1147-1154. [CrossRef]

228. Türk, M.; Tamer, U.; Alver, E.; Çiftçi, H.; Metin, A.U.; Karahan, S. Fabrication and characterization of gold-nanoparticles/chitosan film: A scaffold for L929-fibroblasts. Artif. Cells Nanomed. Biotechnol. 2013, 41, 395-401. [CrossRef]

229. Yeh, Y.-C.; Creran, B.; Rotello, V.M. Gold nanoparticles: Preparation, properties, and applications in bionanotechnology. Nanoscale 2012, 4, 1871-1880. [CrossRef] 
230. Zuber, A.; Purdey, M.; Schartner, E.; Forbes, C.; van der Hoek, B.; Giles, D.; Abell, A.; Monro, T.; Ebendorff-Heidepriem, H. Detection of gold nanoparticles with different sizes using absorption and fluorescence based method. Sensors Actuators B Chem. 2016, 227, 117-127. [CrossRef]

231. Ito, A.; Kamihira, M. Tissue Engineering Using Magnetite Nanoparticles, 1st ed.; Elsevier Inc.: Amsterdam, The Netherlands, 2011; Volume 104.

232. Xiong, F.; Wang, H.; Feng, Y.; Li, Y.; Hua, X.; Pang, X.; Zhang, S.; Song, L.; Zhang, Y.; Gu, N. Cardioprotective activity of iron oxide nanoparticles. Sci. Rep. 2015, 5, 8579. [CrossRef]

233. Madhumathi, K.; Sampath Kumar, T.S. Regenerative potential and anti-bacterial activity of tetracycline loaded apatitic nanocarriers for the treatment of periodontitis. Biomed. Mater. 2014, 9, 35002. [CrossRef]

234. Choi, B.; Cui, Z.-K.; Kim, S.; Fan, J.; Wu, B.M.; Lee, M. Glutamine-chitosan modified calcium phosphate nanoparticles for efficient siRNA delivery and osteogenic differentiation. J. Mater. Chem. B 2015, 3, 6448-6455. [CrossRef]

235. Ding, T.; Luo, Z.J.; Zheng, Y.; Hu, X.Y.; Ye, Z.X. Rapid repair and regeneration of damaged rabbit sciatic nerves by tissue-engineered scaffold made from nano-silver and collagen type I. Injury 2010, 41, 522-527. [CrossRef]

236. Prabhu, S.; Poulose, E.K. Silver nanoparticles: Mechanism of antimicrobial action, synthesis, medical applications, and toxicity effects. Int. Nano Lett. 2012, 2, 32. [CrossRef]

237. Saravanan, S.; Nethala, S.; Pattnaik, S.; Tripathi, A.; Moorthi, A.; Selvamurugan, N. Preparation, characterization and antimicrobial activity of a bio-composite scaffold containing chitosan/nano -hydroxyapatite/nano-silver for bone tissue engineering. Int. J. Biol. Macromol. 2011, 49, 188-193. [CrossRef]

238. Hirota, M.; Hayakawa, T.; Yoshinari, M.; Ametani, A.; Shima, T.; Monden, Y.; Ozawa, T.; Sato, M.; Koyama, C.; Tamai, N.; et al. Hydroxyapatite coating for titanium fibre mesh scaffold enhances osteoblast activity and bone tissue formation. Int. J. Oral Maxillofac. Surg. 2012, 41, 1304-1309. [CrossRef]

239. Holtorf, H.L.; Jansen, J.A.; Mikos, A.G. Ectopic bone formation in rat marrow stromal cell/titanium fiber mesh scaffold constructs: Effect of initial cell phenotype. Biomaterials 2005, 26, 6208-6216. [CrossRef]

240. Fan, X.; Lin, L.; Messersmith, P.B. Surface-initiated polymerization from $\mathrm{TiO}_{2}$ nanoparticle surfaces through a biomimetic initiator: A new route toward polymer-matrix nanocomposites. Compos. Sci. Technol. 2006, 66, 1198-1204. [CrossRef]

241. Kevin, B.; Chang, Y.; Webster, T.J. Increased chondrocyte adhesion on nanotubular anodized titanium. J. Biomed. Mater. Res. Part A 2008, 88, 561-568.

242. Liao, D.L.; Liao, B.Q. Shape, size and photocatalytic activity control of $\mathrm{TiO}_{2}$ nanoparticles with surfactants. J. Photochem. Photobiol. A Chem. 2007, 187, 363-369. [CrossRef]

243. Rakhmatia, Y.D.; Ayukawa, Y.; Atsuta, I.; Furuhashi, A.; Koyano, K. Fibroblast attachment onto novel titanium mesh membranes for guided bone regeneration. Odontology 2015, 103, 218-226. [CrossRef] [PubMed]

244. Shi, Z.; Huang, X.; Cai, Y.; Tang, R.; Yang, D. Size effect of hydroxyapatite nanoparticles on proliferation and apoptosis of osteoblast-like cells. Acta Biomater. 2009, 5, 338-345. [CrossRef] [PubMed]

245. Webster, T.J.; Ergun, C.; Doremus, R.H.; Siegel, R.W.; Bizios, R. Specific proteins mediate enhanced osteoblast adhesion on nanophase ceramics. J. Biomed. Mater. Res. 2000, 51, 475-483. [CrossRef]

246. Lee, J.; Sieweke, J.H.; Rodriguez, N.A.; Schüpbach, P.; Lindström, H.; Susin, C.; Wikesjö, U.M.E. Evaluation of nano-technology-modified zirconia oral implants: A study in rabbits. J. Clin. Periodontol. 2009, 36, 610-617. [CrossRef] [PubMed]

247. Opalinska, A.; Malka, I.; Dzwolak, W.; Chudoba, T.; Presz, A.; Lojkowski, W. Size-dependent density of zirconia nanoparticles. Beilstein J. Nanotechnol. 2015, 6, 27-35. [CrossRef] [PubMed]

248. Park, Y.K.; Tadd, E.H.; Zubris, M.; Tannenbaum, R. Size-controlled synthesis of alumina nanoparticles from aluminum alkoxides. Mater. Res. Bull. 2005, 40, 1506-1512. [CrossRef]

249. Ravindran Girija, A.; Balasubramanian, S. Theragnostic potentials of core/shell mesoporous silica nanostructures. Nanotheranostics 2019, 3, 1-40. [CrossRef]

250. Tarn, D.; Ashley, C.E.; Xue, M.; Carnes, E.C.; Zink, J.I.; Brinker, C.J. Mesoporous silica nanoparticle nanocarriers: Biofunctionality and biocompatibility. Acc. Chem. Res. 2013, 46, 792-801. [CrossRef]

251. Slowing, I.I.; Vivero-Escoto, J.L.; Wu, C.W.; Lin, V.S.Y. Mesoporous silica nanoparticles as controlled release drug delivery and gene transfection carriers. Adv. Drug Deliv. Rev. 2008, 60, 1278-1288. [CrossRef] [PubMed] 
252. Tang, Y.; Zhao, Y.; Wang, X.; Lin, T. Layer-by-layer assembly of silica nanoparticles on 3D fibrous scaffolds: Enhancement of osteoblast cell adhesion, proliferation, and differentiation. J. Biomed. Mater. Res. Part A 2014, 102, 3803-3812. [CrossRef] [PubMed]

253. Zhou, Y.; Quan, G.; Wu, Q.; Zhang, X.; Niu, B.; Wu, B.; Huang, Y.; Pan, X.; Wu, C. Mesoporous silica nanoparticles for drug and gene delivery. Acta Pharm. Sin. B 2018, 8, 165-177. [CrossRef] [PubMed]

254. Anitha, A.; Menon, D.; Koyakutty, M.; Mohan, C.C.; Nair, S.V.; Nair, M.B. Bioinspired composite matrix containing hydroxyapatite-silica core-shell nanorods for bone tissue engineering. ACS Appl. Mater. Interfaces 2017, 9, 26707-26718.

255. Ambekar, R.S.; Kandasubramanian, B. Progress in the advancement of porous biopolymer scaffold: Tissue engineering application. Ind. Eng. Chem. Res. 2019, 58, 6163-6194. [CrossRef]

256. Zhou, P.; Cheng, X.; Xia, Y.; Wang, P.; Zou, K.; Xu, S.; Du, J. Organic/inorganic composite membranes based on poly(l-lactic-co-glycolic acid) and mesoporous silica for effective bone tissue engineering. ACS Appl. Mater. Interfaces 2014, 6, 20895-20903. [CrossRef]

257. Ding, Y.; Li, W.; Correia, A.; Yang, Y.; Zheng, K.; Liu, D.; Schubert, D.W.; Boccaccini, A.R.; Santos, H.A.; Roether, J.A. Electrospun polyhydroxybutyrate/poly( $\varepsilon$-Caprolactone)/sol-gel-derived silica hybrid scaffolds with drug releasing function for bone tissue engineering applications. ACS Appl. Mater. Interfaces 2018, 10, 14540-14548. [CrossRef]

258. Cha, C.; Oh, J.; Kim, K.; Qiu, Y.; Joh, M.; Shin, S.R.; Wang, X.; Camci-Unal, G.; Wan, K.; Liao, R.; et al. Microfluidics-assisted fabrication of gelatin-silica core-shell microgels for injectable tissue constructs. Biomacromolecules 2014, 15, 283-290. [CrossRef]

259. Qiu, K.; Chen, B.; Nie, W.; Zhou, X.; Feng, W.; Wang, W.; Chen, L.; Mo, X.; Wei, Y.; He, C. Electrophoretic deposition of dexamethasone-loaded mesoporous silica nanoparticles onto poly(l-Lactic Acid)/Poly( $\varepsilon$-Caprolactone) composite scaffold for bone tissue engineering. ACS Appl. Mater. Interfaces 2016, 8, 4137-4148. [CrossRef]

260. Jones, J.R. Reprint of: Review of bioactive glass: From Hench to hybrids. Acta Biomater. 2015, 23, S53-S82. [CrossRef]

261. Boccaccini, A.; Maquet, V. Bioresorbable and bioactive polymer/bioglass composites with tailored pore structure for tissue engineering applications. Compos. Sci. Technol. 2003, 63, 2417-2429. [CrossRef]

262. Yu, H.; Peng, J.; Xu, Y.; Chang, J.; Li, H. Bioglass activated skin tissue engineering constructs for wound healing. ACS Appl. Mater. Interfaces 2016, 8, 703-715. [CrossRef] [PubMed]

263. Fernandes, H.R.; Gaddam, A.; Rebelo, A.; Brazete, D.; Stan, G.E.; Ferreira, J.M.F. Bioactive glasses and glass-ceramics for healthcare applications in bone regeneration and tissue engineering. Materials 2018, 11, 2530. [CrossRef]

264. Fiume, E.; Barberi, J.; Verné, E.; Baino, F. Bioactive glasses: From parent 45s 5 composition to scaffold-assisted tissue-healing therapies. J. Funct. Biomater. 2018, 9, 24. [CrossRef] [PubMed]

265. Islam, M.T.; Felfel, R.M.; Abou Neel, E.A.; Grant, D.M.; Ahmed, I.; Hossain, K.M.Z. Bioactive calcium phosphate-based glasses and ceramics and their biomedical applications: A review. J. Tissue Eng. 2017, 8, 2041731417719170. [CrossRef] [PubMed]

266. González, P.; Serra, J.; Liste, S.; Chiussi, S.; León, B.; Pérez-Amor, M. Raman spectroscopic study of bioactive silica based glasses. J. Non. Cryst. Solids 2003, 320, 92-99. [CrossRef]

267. Yan, X.; Yu, C.; Zhou, X.; Tang, J.; Zhao, D. Highly ordered mesoporous bioactive glasses with superior in vitro bone-forming bioactivities. Angew. Chem. Int. Ed. 2004, 43, 5980-5984. [CrossRef]

268. Kumar, P.; Dehiya, B.S.; Sindhu, A.; Kumar, V. Synthesis and characterization of nano bioglass for the application of bone tissue engineering. J. Nanosci. Technol. 2018, 4, 471-474. [CrossRef]

269. De Oliveira, A.A.R.; de Souza, D.A.; Dias, L.L.S.; de Carvalho, S.M.; Mansur, H.S.; de Magalhães Pereira, M. Synthesis, characterization and cytocompatibility of spherical bioactive glass nanoparticles for potential hard tissue engineering applications. Biomed. Mater. 2013, 8, 025011. [CrossRef]

270. Wang, W.; Yeung, K.W.K. Bone grafts and biomaterials substitutes for bone defect repair: A review. Bioact. Mater. 2017, 2, 224-247. [CrossRef] [PubMed]

271. Chen, Q.; Boccaccini, A. Poly(D,L-lactic acid) coated 45S5 Bioglass-based scaffolds: Processing and characterization. J. Biomed. Mater. Res. Part A 2006, 77, 445-457. [CrossRef] [PubMed] 
272. Ravarian, R.; Zhong, X.; Barbeck, M.; Ghanaati, S.; Kirkpatrick, C.J.; Murphy, C.M.; Schindeler, A.; Chrzanowski, W.; Dehghani, F. Nanoscale chemical interaction enhances the physical properties of bioglass composites. ACS Nano 2013, 7, 8469-8483. [CrossRef] [PubMed]

273. Zeng, Q.; Desai, M.S.; Jin, H.-E.; Lee, J.H.; Chang, J.; Lee, S.-W. Self-healing elastin-bioglass hydrogels. Biomacromolecules 2016, 17, 2619-2625. [CrossRef] [PubMed]

274. Marelli, B.; Ghezzi, C.E.; Barralet, J.E.; Boccaccini, A.R.; Nazhat, S.N. Three-dimensional mineralization of dense nanofibrillar collagen-bioglass hybrid scaffolds. Biomacromolecules 2010, 11, 1470-1479. [CrossRef]

275. Misra, S.K.; Nazhat, S.N.; Valappil, S.P.; Moshrefi-Torbati, M.; Wood, R.J.K.; Roy, I.; Boccaccini, A.R. fabrication and characterization of biodegradable poly(3-hydroxybutyrate) composite containing bioglass. Biomacromolecules 2007, 8, 2112-2119. [CrossRef]

276. Fernandes, J.S.; Martins, M.; Neves, N.M.; Fernandes, M.H.V.; Reis, R.L.; Pires, R.A. Intrinsic antibacterial borosilicate glasses for bone tissue engineering applications. ACS Biomater. Sci. Eng. 2016, 2, 1143-1150. [CrossRef]

277. Xu, Y.; Luong, D.; Walker, J.M.; Dean, D.; Becker, M.L. Modification of poly(propylene fumarate)-bioglass composites with peptide conjugates to enhance bioactivity. Biomacromolecules 2017, 18, 3168-3177. [CrossRef]

278. Pepla, E.; Besharat, L.K.; Palaia, G.; Tenore, G.; Migliau, G. Nano-hydroxyapatite and its applications in preventive, restorative and regenerative dentistry: A review of literature. Ann. Stomatol. 2014, 5, 108-114. [CrossRef]

279. Leventouri, T.; Antonakos, A.; Kyriacou, A.; Venturelli, R.; Liarokapis, E.; Perdikatsis, V. Crystal structure studies of human dental apatite as a function of age. Int. J. Biomater. 2009, 2009, 698547. [CrossRef]

280. Freed, L.E.; Vunjak-Novakovic, G.; Biron, R.J.; Eagles, D.B.; Lesnoy, D.C.; Barlow, S.K.; Langer, R. Biodegradable polymer scaffolds for tissue engineering. Nat. Biotechnol. 1994, 12, 689-693. [CrossRef] [PubMed]

281. Isikli, C.; Hasirci, V.; Hasirci, N. Development of porous chitosan-gelatin/hydroxyapatite composite scaffolds for hard tissue-engineering applications. J. Tissue Eng. Regen. Med. 2011, 6, 135-143. [CrossRef] [PubMed]

282. Klein, C.; Driessen, A.A.; Degroot, K.; Vandenhooff, A. Biodegradation behavior of various calcium-phosphate materials in bone tissue. J. Biomed. Mater. Res. 1983, 17, 769-784. [CrossRef] [PubMed]

283. Rezwan, K.; Chen, Q.Z.; Blaker, J.J.; Boccaccini, A.R. Biodegradable and bioactive porous polymer/inorganic composite scaffolds for bone tissue engineering. Biomaterials 2006, 27, 3413-3431. [CrossRef] [PubMed]

284. Guzmán Vázquez, C.; Piña Barba, C.; Munguía, N. Stoichiometric hydroxyapatite obtained by precipitation and sol gel processes. Rev. Mex. Fis. 2005, 51, 284-293.

285. Li, J.; Lu, X.L.; Zheng, Y.F. Effect of surface modified hydroxyapatite on the tensile property improvement of HA/PLA composite. Appl. Surf. Sci. 2008, 255, 494-497. [CrossRef]

286. Dorozhkin, S.V. Calcium orthophosphate cements for biomedical application. J. Mater. Sci. 2008, 43, 3028-3057. [CrossRef]

287. Narasaraju, T.S.B.; Phebe, D.E. Some physico-chemical aspects of hydroxylapatite. J. Mater. Sci. 1996, 31, 1-21. [CrossRef]

288. Fathi, M.H.; Hanifi, A.; Mortazavi, V. Preparation and bioactivity evaluation of bone-like hydroxyapatite nanopowder. J. Mater. Process. Technol. 2008, 202, 536-542. [CrossRef]

289. Sopyan, I.; Singh, R.; Hamdi, M. Synthesis of nano sized hydroxyapatite powder using sol-gel technique and its conversion to dense and porous bodies. Indian J. Chem. Sect. A 2008, 47, 1626-1631.

290. Kattimani, V.S.; Kondaka, S.; Lingamaneni, K.P. Hydroxyapatite-Past, present, and future in bone regeneration. Bone Tissue Regen. Insights 2016, 7, S36138. [CrossRef]

291. Woodard, J.R.; Hilldore, A.J.; Lan, S.K.; Park, C.J.; Morgan, A.W.; Eurell, J.A.C.; Clark, S.G.; Wheeler, M.B.; Jamison, R.D.; Wagoner Johnson, A.J. The mechanical properties and osteoconductivity of hydroxyapatite bone scaffolds with multi-scale porosity. Biomaterials 2007, 28, 45-54. [CrossRef] [PubMed]

292. Gao, X.; Song, J.; Ji, P.; Zhang, X.; Li, X.; Xu, X.; Wang, M.; Zhang, S.; Deng, Y.; Deng, F.; et al. Polydopamine-templated hydroxyapatite reinforced polycaprolactone composite nanofibers with enhanced cytocompatibility and osteogenesis for bone tissue engineering. ACS Appl. Mater. Interfaces 2016, 8, 3499-3515. [CrossRef] [PubMed]

293. Jiang, L.; Li, Y.; Xiong, C.; Su, S.; Ding, H. Preparation and properties of bamboo fiber/nano-hydroxyapatite/ poly(lactic-co-glycolic) composite scaffold for bone tissue engineering. ACS Appl. Mater. Interfaces 2017, 9, 4890-4897. [CrossRef] [PubMed] 
294. Salarian, M.; Xu, W.Z.; Wang, Z.; Sham, T.-K.; Charpentier, P.A. Hydroxyapatite--TiO 2 -based nanocomposites synthesized in supercritical co2 for bone tissue engineering: Physical and mechanical properties. ACS Appl. Mater. Interfaces 2014, 6, 16918-16931. [CrossRef]

295. Liang, X.; Duan, P.; Gao, J.; Guo, R.; Qu, Z.; Li, X.; He, Y.; Yao, H.; Ding, J. Bilayered PLGA/PLGA-HAp composite scaffold for osteochondral tissue engineering and tissue regeneration. ACS Biomater. Sci. Eng. 2018, 4, 3506-3521. [CrossRef]

296. Fu, S.; Wang, X.; Guo, G.; Shi, S.; Liang, H.; Luo, F.; Wei, Y.; Qian, Z. Preparation and characterization of nano-hydroxyapatite/poly( $\varepsilon$-caprolactone)-poly(ethylene glycol)-poly( $\varepsilon$-caprolactone) composite fibers for tissue engineering. J. Phys. Chem. C 2010, 114, 18372-18378. [CrossRef]

297. Liu, M.; Liu, H.; Sun, S.; Li, X.; Zhou, Y.; Hou, Z.; Lin, J. Multifunctional Hydroxyapatite/Na(Y/Gd)F $\mathrm{F}_{4}: \mathrm{Yb}^{3+}, \mathrm{Er}^{3+}$ composite fibers for drug delivery and dual modal imaging. Langmuir 2014, 30, 1176-1182. [CrossRef]

298. Li, Z.; Liu, Z.; Yin, M.; Yang, X.; Yuan, Q.; Ren, J.; Qu, X. Aptamer-capped multifunctional mesoporous strontium hydroxyapatite nanovehicle for cancer-cell-responsive drug delivery and imaging. Biomacromolecules 2012, 13, 4257-4263. [CrossRef]

299. Wang, L.; Hu, C.; Shao, L. The antimicrobial activity of nanoparticles: Present situation and prospects for the future. Int. J. Nanomed. 2017, 12, 1227-1249. [CrossRef]

300. Wu, C.; Lee, C.; Chen, J.; Kuo, S.; Fan, S.; Cheng, C.; Chang, F.; Ko, F. Microwave-assisted electroless deposition of silver nanoparticles onto multiwalled carbon nanotubes. Int. J. Electrochem. Sci. 2012, 7, 4133-4142.

301. Ciobanu, C.S.; Iconaru, S.L.; Coustumer, P.L.; Constantin, L.V.; Predoi, D. Antibacterial activity of silver-doped hydroxyapatite nanoparticles against gram-positive and gram-negative bacteria. Nanoscale Res. Lett. 2012, 7 , 1-9. [CrossRef] [PubMed]

302. Melnikov, O.V.; Gorbenko, O.Y.; Markelova, M.N.; Kaul, A.R.; Atsarkin, V.A.; Demidov, V.V.; Soto, C.; Roy, E.J.; Odintsov, B.M. Ag-doped manganite nanoparticles: New materials for temperature-controlled medical hyperthermia. J. Biomed. Mater. Res. A 2009, 91, 1048-1055. [CrossRef] [PubMed]

303. Bapat, R.A.; Chaubal, T.V.; Joshi, C.P.; Bapat, P.R.; Choudhury, H.; Pandey, M.; Gorain, B.; Kesharwani, P. An overview of application of silver nanoparticles for biomaterials in dentistry. Mater. Sci. Eng. C 2018, 91, 881-898. [CrossRef] [PubMed]

304. Rai, M.; Yadav, A.; Gade, A. Silver nanoparticles as a new generation of antimicrobials. Biotechnol. Adv. 2009, 27, 76-83. [CrossRef]

305. Krishnaraj, C.; Jagan, E.G.; Rajasekar, S.; Selvakumar, P.; Kalaichelvan, P.T.; Mohan, N. Synthesis of silver nanoparticles using Acalypha indica leaf extracts and its antibacterial activity against water borne pathogens. Colloids Surfaces B Biointerfaces 2010, 76, 50-56. [CrossRef]

306. Jung, W.K.; Koo, H.C.; Kim, K.W.; Shin, S.; Kim, S.H.; Park, Y.H. Antibacterial Activity and Mechanism of Action of the Silver Ion in Staphylococcus aureus and Escherichia coli. Appl. Environ. Microbiol. 2008, 74, 2171-2178. [CrossRef]

307. Mihai, M.M.; Dima, M.B.; Dima, B.; Holban, A.M. Nanomaterials for Wound Healing and Infection Control. Materials 2019, 12, 2176. [CrossRef]

308. Burdușel, A.-C.; Gherasim, O.; Grumezescu, A.M.; Mogoantă, L.; Ficai, A.; Andronescu, E. Biomedical applications of silver nanoparticles: An up-to-date overview. Nanomaterials 2018, 8, 681. [CrossRef]

309. Stetciura, I.Y.; Markin, A.V.; Ponomarev, A.N.; Yakimansky, A.V.; Demina, T.S.; Grandfils, C.; Volodkin, D.V.; Gorin, D.A. New surface-enhanced raman scattering platforms: Composite calcium carbonate microspheres coated with astralen and silver nanoparticles. Langmuir 2013, 29, 4140-4147. [CrossRef]

310. Zan, X.; Kozlov, M.; McCarthy, T.J.; Su, Z. Covalently attached, silver-doped Poly(vinyl alcohol) hydrogel films on Poly(1-lactic acid). Biomacromolecules 2010, 11, 1082-1088. [CrossRef] [PubMed]

311. García-Astrain, C.; Chen, C.; Burón, M.; Palomares, T.; Eceiza, A.; Fruk, L.; Corcuera, M.Á.; Gabilondo, N. Biocompatible hydrogel nanocomposite with covalently embedded silver nanoparticles. Biomacromolecules 2015, 16, 1301-1310. [CrossRef] [PubMed]

312. Cao, H.; Zhang, W.; Meng, F.; Guo, J.; Wang, D.; Qian, S.; Jiang, X.; Liu, X.; Chu, P.K. Osteogenesis Catalyzed by Titanium-Supported Silver Nanoparticles. ACS Appl. Mater. Interfaces 2017, 9, 5149-5157. [CrossRef] [PubMed] 
313. Patrascu, J.M.; Nedelcu, I.A.; Sonmez, M.; Ficai, D.; Ficai, A.; Vasile, B.S.; Ungureanu, C.; Albu, M.G.; Andor, B.; Andronescu, E.; et al. Composite scaffolds based on silver nanoparticles for biomedical applications. J. Nanomater. 2015, 2015, 587989. [CrossRef]

314. Huang, X.; Qian, W.; El-Sayed, I.H.; El-Sayed, M.A. The potential use of the enhanced nonlinear properties of gold nanospheres in photothermal cancer therapy. Lasers Surg. Med. 2007, 39, 747-753. [CrossRef]

315. Vieira, S.; Vial, S.; Maia, F.R.; Carvalho, M.R.; Reis, R.L.; Granja, P.L.; Oliveira, J.M. Gellan gum-coated gold nanorods: An intracellular nanosystem for bone tissue engineering. RSC Adv. 2015, 5, 77996-78005. [CrossRef]

316. Yuan, H.; Khoury, C.G.; Wilson, C.M.; Grant, G.A.; Bennett, A.J.; Vo-Dinh, T. In vivo particle tracking and photothermal ablation using plasmon-resonant gold nanostars. Nanomed. Nanotechnol. Biol. Med. 2012, 8, 1355-1363. [CrossRef]

317. Zhang, Q.; Uchaker, E.; Candelaria, S.L.; Cao, G. Nanomaterials for energy conversion and storage. Chem. Soc. Rev. 2013, 42, 3127-3171. [CrossRef]

318. Li, H.; Pan, S.; Xia, P.; Chang, Y.; Fu, C.; Kong, W.; Yu, Z.; Wang, K.; Yang, X.; Qi, Z. Advances in the applications of gold nanoparticles in bone tissue engineering. J. Biol. Eng. 2020, 14, 14. [CrossRef]

319. Daniel, M.-C.; Astruc, D. Gold Nanoparticles: assembly, supramolecular chemistry, quantum-size-related properties, and applications toward biology, catalysis, and nanotechnology. Chem. Rev. 2004, 104, 293-346. [CrossRef]

320. Aldewachi, H.; Chalati, T.; Woodroofe, M.N.; Bricklebank, N.; Sharrack, B.; Gardiner, P. Gold nanoparticle-based colorimetric biosensors. Nanoscale 2018, 10, 18-33. [CrossRef]

321. Morita, M.; Tachikawa, T.; Seino, S.; Tanaka, K.; Majima, T. Controlled synthesis of gold nanoparticles on fluorescent nanodiamond via electron-beam-induced reduction method for dual-modal optical and electron bioimaging. ACS Appl. Nano Mater. 2018, 1, 355-363. [CrossRef]

322. Zhang, Y.S.; Wang, Y.; Wang, L.; Wang, Y.; Cai, X.; Zhang, C.; Wang, L.V.; Xia, Y. Labeling human mesenchymal stem cells with gold nanocages for in vitro and in vivo tracking by two-photon microscopy and photoacoustic microscopy. Theranostics 2013, 3, 532-543. [CrossRef] [PubMed]

323. Khlebtsov, N.; Bogatyrev, V.; Dykman, L.; Khlebtsov, B.; Staroverov, S.; Shirokov, A.; Matora, L.; Khanadeev, V.; Pylaev, T.; Tsyganova, N.; et al. Analytical and theranostic applications of gold Na-noparticles and multifunctional nanocomposites. Theranostics 2013, 3, 167-180. [CrossRef] [PubMed]

324. Sun, T.-M.; Wang, Y.-C.; Wang, F.; Du, J.; Mao, C.; Sun, C.-Y.; Tang, R.; Liu, Y.; Zhu, J.; Zhu, Y.-H.; et al. Cancer stem cell therapy using doxorubicin conjugated to gold nanoparticles via hydrazone bonds. Biomaterials 2013, 35, 836-845. [CrossRef] [PubMed]

325. Yu, M.; Lei, B.; Gao, C.; Yan, J.; Ma, P.X. Optimizing surface-engineered ultra-small gold nanoparticles for highly efficient miRNA delivery to enhance osteogenic differentiation of bone mesenchimal stromal cells. Nano Res. 2017, 10, 49-63. [CrossRef]

326. Vial, S.; Reis, R.L.; Oliveira, J.M. Recent advances using gold nanoparticles as a promising multimodal tool for tissue engineering and regenerative medicine. Curr. Opin. Solid State Mater. Sci. 2017, 21, 92-112. [CrossRef]

327. Khorasani, A.; Goldberg, M.; Doeven, E.; Littlefair, G. Titanium in biomedical applications-Properties and fabrication: A Review. J. Biomater. Tissue Eng. 2015, 5, 593-619. [CrossRef]

328. Hong, Y.C.; Kim, J.H.; Bang, C.U.; Uhm, H.S. Gas-phase synthesis of nitrogen-doped $\mathrm{TiO}_{2}$ nanorods by microwave plasma torch at atmospheric pressure. Phys. Plasmas 2005, 12, 114501. [CrossRef]

329. Dar, M.I.; Chandiran, A.K.; Gratzel, M.; Nazeeruddin, M.K.; Shivashankar, S.A. Controlled synthesis of $\mathrm{TiO}_{2}$ nanospheres using a microwave assisted approach for their application in dye-sensitized solar cells. J. Mater. Chem. A 2014, 2, 1662-1667. [CrossRef]

330. Jeon, S.; Braun, P.V. Hydrothermal synthesis of er-doped luminescent $\mathrm{TiO}_{2}$ nanoparticles. Chem. Mater. 2003, 15, 1256-1263. [CrossRef]

331. Ramakrishnan, V.M.; Natarajan, M.; Santhanam, A.; Asokan, V.; Velauthapillai, D. Size controlled synthesis of $\mathrm{TiO}_{2}$ nanoparticles by modified solvothermal method towards effective photocatalitic and photovoltaic applications. Mater. Res. 2018, 97, 351-360.

332. Loryuenyong, V.; Angamnuaysiri, K.; Sukcharoenpong, J.; Suwannasri, A. Sol-gel derived mesoporous titania nanoparticles: Effects of calcination temperature and alcoholic solvent on the photocatalytic behavior. Ceram. Int. 2012, 38, 2233-2237. [CrossRef] 
333. Maheswari, D.; Venkatachalam, P. Enhanced efficiency and improved photocatalytic activity of 1:1 composite mixture of $\mathrm{TiO}_{2}$ nanoparticles and nanotubes in dye-sensitized solar cell. Bull. Mater. Sci. 2014, 37, 1489-1496. [CrossRef]

334. Cai, Q.; Paulose, M.; Varghese, O.K.; Grimes, C.A. The effect of electrolyte composition on the fabrication of self-organized titanium oxide nanotube arrays by anodic oxidation. J. Mater. Res. 2005, 20, 230-236. [CrossRef]

335. Tang, Y.; Tao, J.; Zhang, Y.; Wu, T.; Tao, H.; Bao, Z. Preparation and characterization of $\mathrm{TiO}_{2}$ nanotube arrays via anodization of titanium films deposited on FTO conducting glass at room temperature. Acta Physico Chimica Sin. 2008, 24, 2191-2197. [CrossRef]

336. Ding, Z.; Hu, X.; Yue, P.; Lu, M.; Greenfield, P. Synthesis of anatase $\mathrm{TiO}_{2}$ supported on porous solids by chemical vapor deposition. Catal. Today 2001, 68, 173-182. [CrossRef]

337. Lee, H.; Song, M.; Jurng, J.; Park, Y.-K. The synthesis and coating process of $\mathrm{TiO}_{2}$ nanoparticles using CVD process. Powder Technol. 2011, 214, 64-68. [CrossRef]

338. Arami, H.; Mazloumi, M.; Khalifehzadeh, R.; Sadrnezhaad, S.K. Sonochemical preparation of $\mathrm{TiO}_{2}$ nanoparticles. Mater. Lett. 2007, 61, 4559-4561. [CrossRef]

339. Guo, J.; Zhu, S.; Chen, Z.; Li, Y.; Yu, Z.; Liu, Q.; Li, J.; Feng, C.; Zhang, D. Sonochemical synthesis of $\mathrm{TiO}_{2}$ nanoparticles on graphene for use as photocatalyst. Ultrason. Sonochem. 2011, 18, 1082-1090. [CrossRef]

340. Nasrollahzadeh, M.; Atarod, M.; Jaleh, B.; Gandomirouzbahani, M. In situ green synthesis of Ag nanoparticles on graphene oxide/ $/ \mathrm{TiO}_{2}$ nanocomposite and their catalytic activity for the reduction of 4-nitrophenol, Congo red and methylene blue. Ceram. Int. 2016, 42, 8587-8596. [CrossRef]

341. Sivaranjani, V.; Philominathan, P. Synthesize of Titanium dioxide nanoparticles using Moringa oleifera leaves and evaluation of wound healing activity. Wound Med. 2016, 12, 1-5. [CrossRef]

342. Goutam, S.P.; Saxena, G.; Singh, V.; Yadav, A.K.; Bharagava, R.N.; Thapa, K.B. Green synthesis of $\mathrm{TiO}_{2}$ nanoparticles using leaf extract of Jatropha curcas L. for photocatalytic degradation of tannery wastewater. Chem. Eng. J. 2018, 336, 386-396. [CrossRef]

343. Paunesku, T.; Rajh, T.; Wiederrecht, G.; Maser, J.; Vogt, S.; Stojićević, N.; Protić, M.; Lai, B.; Oryhon, J.; Thurnauer, M.; et al. Biology of $\mathrm{TiO}_{2}$-oligonucleotide nanocomposites. Nat. Mater. 2003, 2, 343-346. [CrossRef] [PubMed]

344. Paunesku, T.; Vogt, S.; Lai, B.; Maser, J.; Stojićević, N.; Thurn, K.T.; Osipo, C.; Liu, H.; Legnini, D.; Wang, Z.; et al. Intracellular distribution of $\mathrm{TiO}_{2}$-DNA oligonucleotide nanoconjugates directed to nucleolus and mitochondria indicates sequence specificity. Nano Lett. 2007, 7, 596-601. [CrossRef]

345. Cesmeli, S.; Biray Avci, C. Application of titanium dioxide $\left(\mathrm{TiO}_{2}\right)$ nanoparticles in cancer therapies. J. Drug Target. 2019, 27, 762-766. [CrossRef]

346. Roy, P.; Berger, S.; Schmuki, P. TiO 2 Nanotubes: Synthesis and applications. Angew. Chem. Int. Ed. 2011, 50, 2904-2939. [CrossRef]

347. Losic, D.; Aw, M.; Santos, A.; Gulati, K.; Bariana, M. Titania nanotube arrays for local drug delivery: Recent advances and perspectives. Expert Opin. Drug Deliv. 2014, 12, 103-127. [CrossRef]

348. Wang, Q.; Huang, J.-Y.; Li, H.-Q.; Chen, Z.; Zhao, A.Z.-J.; Wang, Y.; Zhang, K.-Q.; Sun, H.-T.; Al-Deyab, S.S.; Lai, Y.-K. $\mathrm{TiO}_{2}$ nanotube platforms for smart drug delivery: A review. Int. J. Nanomed. 2016, 11, 4819-4834.

349. Wu, S.; Weng, Z.; Liu, X.; Yeung, K.W.K.; Chu, P.K. Functionalized $\mathrm{TiO}_{2}$ based nanomaterials for biomedical applications. Adv. Funct. Mater. 2014, 24, 5464-5481. [CrossRef]

350. Tiainen, H.; Monjo, M.; Knychala, J.; Nilsen, O.; Lyngstadaas, S.P.; Ellingsen, J.E.; Haugen, H.J. The effect of fluoride surface modification of ceramic $\mathrm{TiO}_{2}$ on the surface properties and biological response of osteoblastic cells in vitro. Biomed. Mater. 2011, 6, 45006. [CrossRef] [PubMed]

351. Tiainen, H.; Lyngstadaas, S.P.; Ellingsen, J.E.; Haugen, H.J. Ultra-porous titanium oxide scaffold with high compressive strength. J. Mater. Sci. Mater. Med. 2010, 21, 2783-2792. [CrossRef]

352. Tabriz, K.R.; Katbab, A.A. Preparation of modified- $-\mathrm{TiO}_{2} / \mathrm{PLA}$ nanocomposite films: Micromorphology, photo-degradability and antibacterial studies. AIP Conf. Proc. 2017, 1914, 70009.

353. Wu, X.; Liu, X.; Wei, J.; Ma, J.; Deng, F.; Wei, S. Nano-TiO $2 /$ PEEK bioactive composite as a bone substitute material: In vitro and in vivo studies. Int. J. Nanomed. 2012, 7, 1215-1225. 
354. Eslami, H.; Azimi Lisar, H.; Jafarzadeh Kashi, T.S.; Tahriri, M.; Ansari, M.; Rafiei, T.; Bastami, F.; Shahin-Shamsabadi, A.; Mashhadi Abbas, F.; Tayebi, L. Poly(lactic-co-glycolic acid)(PLGA)/TiO 2 nanotube bioactive composite as a novel scaffold for bone tissue engineering: In vitro and in vivo studies. Biologicals 2018, 53, 51-62. [CrossRef] [PubMed]

355. Paušová, Š.; Krýsa, J.; Jirkovský, J.; Prevot, V.; Mailhot, G. Preparation of $\mathrm{TiO}_{2}-\mathrm{SiO}_{2}$ composite photocatalysts for environmental applications. J. Chem. Technol. Biotechnol. 2014, 89, 1129-1135. [CrossRef]

356. Liu, S.; Tao, W.; Li, J.; Yang, Z.; Liu, F. Study on the formation process of $\mathrm{Al} 2 \mathrm{O} 3-\mathrm{TiO}_{2}$ composite powders. Powder Technol. 2005, 155, 187-192. [CrossRef]

357. Omid-Bakhtiari, M.; Nasr-Esfahani, M.; Nourmohamadi, A. TiO ${ }_{2}$-Bioactive glass nanostructure composite films produced by a sol-gel method: In vitro behavior and UV-enhanced bioactivity. J. Mater. Eng. Perform. 2014, 23, 285-293. [CrossRef]

358. Oktar, F.N. Hydroxyapatite-TiO 2 composites. Mater. Lett. 2006, 60, 2207-2210. [CrossRef]

359. Khalid, N.R.; Bilal Tahir, M.; Majid, A.; Ahmed, E.; Ahmad, M.; Khalid, S.; Ahmed, W. TiO ${ }_{2}$-graphene-based composites: Synthesis, characterization, and application in photocatalysis of organic pollutants. In Micro and Nanomanufacturing Volume II; Jackson, M.J., Ahmed, W., Eds.; Springer International Publishing: Cham, Switzerland, 2018; pp. 95-122.

360. Roguska, A.; Pisarek, M.; Andrzejczuk, M.; Dolata, M.; Lewandowska, M.; Janik-Czachor, M. Characterization of a calcium phosphate- $\mathrm{TiO}_{2}$ nanotube composite layer for biomedical applications. Mater. Sci. Eng. C 2011, 31, 906-914. [CrossRef]

361. Rehman, F.U.; Zhao, C.; Jiang, H.; Wang, X. Biomedical applications of nano-titania in theranostics and photodynamic therapy. Biomater. Sci. 2016, 4, 40-54. [CrossRef] [PubMed]

362. Chen, J.; Dong, X.; Zhao, J.; Tang, G. In vivo acute toxicity of titanium dioxide nanoparticles to mice after intraperitioneal injection. J. Appl. Toxicol. 2009, 29, 330-337. [CrossRef] [PubMed]

363. Chennell, P.; Feschet-Chassot, E.; Devers, T.; Awitor, K.O.; Descamps, S.; Sautou, V. In vitro evaluation of $\mathrm{TiO}_{2}$ nanotubes as cefuroxime carriers on orthopaedic implants for the prevention of periprosthetic joint infections. Int. J. Pharm. 2013, 455, 298-305. [CrossRef] [PubMed]

364. Kumar, P.; Dehiya, B.S.; Sindhu, A. Bioceramics for hard tissue engineering applications: A review. Int. J. Appl. Eng. Res. 2018, 13, 2744-2752.

365. Hentrich, R.L.; Graves, G.A.; Stein, H.G.; Bajpai, P.K. An evaluation of inert and resorbale ceramics for future clinical orthopedic applications. J. Biomed. Mater. Res. 1971, 5, 25-51. [CrossRef] [PubMed]

366. Christel, P.; Meunier, A.; Heller, M.; Torre, J.P.; Peille, C.N. Mechanical properties and short-term in vivo evaluation of yttrium-oxide-partially-stabilized zirconia. J. Biomed. Mater. Res. 1989, 23, 45-61. [CrossRef] [PubMed]

367. Afzal, M.A.F.; Kesarwani, P.; Reddy, K.M.; Kalmodia, S.; Basu, B.; Balani, K. Functionally graded hydroxyapatite-alumina-zirconia biocomposite: Synergy of toughness and biocompatibility. Mater. Sci. Eng. C 2012, 32, 1164-1173. [CrossRef]

368. Cales, B.; Stefani, Y.; Lilley, E. Long-term in vivo and in vivo aging of a zirconia ceramic used in orthopaedy. J. Biomed. Mater. Res. 1994, 28, 619-624. [CrossRef] [PubMed]

369. Hu, C.Y.; Yoon, T.-R. Recent updates for biomaterials used in total hip arthroplasty. Biomater. Res. 2018, 22, 1-12. [CrossRef]

370. Vagkopoulou, T.; Koutayas, S.O.; Koidis, P.; Strub, J.R. Zirconia in dentistry: Part 1. Discovering the nature of an upcoming bioceramic. Eur. J. Esthet. Dent. 2009, 4, 130-151.

371. Tosiriwatanapong, T.; Singhatanadgit, W. Zirconia-based biomaterials for hard tissue reconstruction. Bone Tissue Regen. Insights 2018, 9. [CrossRef]

372. Aboushelib, M.N.; Shawky, R. Osteogenesis ability of CAD/CAM porous zirconia scaffolds enriched with nano-hydroxyapatite particles. Int. J. Implant Dent. 2017, 3, 21. [CrossRef] [PubMed]

373. Mushahary, D.; Sravanthi, R.; Li, Y.; Kumar, M.J.; Harishankar, N.; Hodgson, P.D.; Wen, C.; Pande, G. Zirconium, calcium, and strontium contents in magnesium based biodegradable alloys modulate the efficiency of implant-induced osseointegration. Int. J. Nanomed. 2013, 8, 2887-2902.

374. Ramaswamy, Y.; Wu, C.; Van Hummel, A.; Combes, V.; Grau, G.; Zreiqat, H. The responses of osteoblasts, osteoclasts and endothelial cells to zirconium modified calcium-silicate-based ceramic. Biomaterials 2008, 29, 4392-4402. [CrossRef] 
375. Kim, H.-W.; Kim, H.-E.; Knowles, J.C. Hard-tissue-engineered zirconia porous scaffolds with hydroxyapatite sol-gel and slurry coatings. J. Biomed. Mater. Res. Part B. 2004, 70, 270-277. [CrossRef]

376. Chevalier, J.; Gremillard, L. Zirconia as a biomaterial. Compr. Biomater. 2011, 1, 95-108.

377. Alizadeh, A.; Moztarzadeh, F.; Ostad, S.N.; Azami, M.; Geramizadeh, B.; Hatam, G.; Bizari, D.; Tavangar, S.M.; Vasei, M.; Ai, J. Synthesis of calcium phosphate-zirconia scaffold and human endometrial adult stem cells for bone tissue engineering. Artif. Cells Nanomed. Biotechnol. 2016, 44, 66-73. [CrossRef]

378. Jayakumar, R.; Ramachandran, R.; Sudheesh Kumar, P.T.; Divyarani, V.V.; Srinivasan, S.; Chennazhi, K.P.; Tamura, H.; Nair, S.V. Fabrication of chitin-chitosan/nano $\mathrm{ZrO}_{2}$ composite scaffolds for tissue engineering applications. Int. J. Biol. Macromol. 2011, 49, 274-280. [CrossRef]

379. Teimouri, A.; Ebrahimi, R.; Emadi, R.; Beni, B.H.; Chermahini, A.N. Nano-composite of silk fibroin-chitosan/Nano $\mathrm{ZrO}_{2}$ for tissue engineering applications: Fabrication and morphology. Int. J. Biol. Macromol. 2015, 76, 292-302. [CrossRef]

380. Bermúdez-Reyes, B.; del Refugio Lara-Banda, M.; Reyes-Zarate, E.; Rojas-Martínez, A.; Camacho, A.; Moncada-Saucedo, N.; Pérez-Silos, V.; García-Ruiz, A.; Guzmán-López, A.; Peña-Martínez, V.; et al. Effect on growth and osteoblast mineralization of hydroxyapatite-zirconia $\left(\mathrm{HA}-\mathrm{ZrO}_{2}\right)$ obtained by a new low temperature system. Biomed. Mater. 2018, 13, 035001. [CrossRef]

381. Sa, M.-W.; Nguyen, B.-N.B.; Moriarty, R.A.; Kamalitdinov, T.; Fisher, J.P.; Kim, J.Y. Fabrication and evaluation of 3D printed BCP scaffolds reinforced with $\mathrm{ZrO}_{2}$ for bone tissue applications. Biotechnol. Bioeng. 2018, 115, 989-999. [CrossRef] [PubMed]

382. Bhowmick, A.; Pramanik, N.; Mitra, T.; Gnanamani, A.; Das, M.; Kundu, P.P. Mechanical and biological investigations of chitosan-polyvinyl alcohol based $\mathrm{ZrO}_{2}$ doped porous hybrid composites for bone tissue engineering applications. New J. Chem. 2017, 41, 7524-7530. [CrossRef]

383. Wang, X.; Chen, D.; Cao, L.; Li, Y.; Boyd, B.J.; Caruso, R.A. Mesoporous titanium zirconium oxide nanospheres with potential for drug delivery applications. ACS Appl. Mater. Interfaces 2013, 5, 10926-10932. [CrossRef] [PubMed]

384. Abánades Lázaro, I.; Haddad, S.; Rodrigo-Muñoz, J.M.; Marshall, R.J.; Sastre, B.; del Pozo, V.; Fairen-Jimenez, D.; Forgan, R.S. Surface-functionalization of Zr-Fumarate MOF for selective cytotoxicity and immune system compatibility in nanoscale drug delivery. ACS Appl. Mater. Interfaces 2018, 10, 31146-31157. [CrossRef]

385. Milak, P.; Minatto, F.; De Noni, A., Jr.; Montedo, O. Wear performance of alumina-based ceramics-A review of the influence of microstructure on erosive wear. Cerâmica 2015, 61, 88-103. [CrossRef]

386. Gaber, A.A.A.-A.; Ibrahim, D.M.; Abd-AImohsen, F.F.; El-Zanati, M.M. Synthesis of alumina, titania, and alumina-titania hydrophobic membranes via sol-gel polymeric route. J. Anal. Sci. Technol. 2013, 4, 18. [CrossRef]

387. Elsberg, L.; Moore, M. Total hip replacement: Metal-on-metal systems. In Clinical Performance of Skeletal Prostheses; Hench, L.L., Wilson, J., Eds.; Springer: Dordrecht, The Netherlands, 1996; pp. 57-70.

388. Al-Sanabani, F.A.; Madfa, A.A.; Al-Qudaimi, N.H. Alumina ceramic for dental applications: A review article. Am. J. Mater. Res. 2014, 1, 26-34.

389. Lee, K.-L.; Hsu, H.-Y.; You, M.-L.; Chang, C.-C.; Pan, M.-Y.; Shi, X.; Ueno, K.; Misawa, H.; Wei, P.-K. Highly sensitive aluminum-based biosensors using tailorable fano resonances in capped nanostructures. Sci. Rep. 2017, 7, 44104. [CrossRef]

390. Bartzsch, H.; Glöß, D.; Böcher, B.; Frach, P.; Goedicke, K. Properties of $\mathrm{SiO}_{2}$ and $\mathrm{Al}_{2} \mathrm{O}_{3}$ films for electrical insulation applications deposited by reactive pulse magnetron sputtering. Surf. Coat. Technol. 2003, 174, 774-778. [CrossRef]

391. Elisabet, X.-P.; Josep, F.-B.; Josep, P.; Marsal, F.L. Mesoporous alumina as a biomaterial for biomedical applications. Open Mater. Sci. 2015, 2, 13.

392. Mohanty, M. Medical Applications of alumina ceramics. Trans. Indian Ceram. Soc. 1995, 54, $200-204$. [CrossRef]

393. Sansone, V.; Pagani, D.; Melato, M. The effects on bone cells of metal ions released from orthopaedic implants. A review. Clin. Cases Miner. Bone Metab. 2013, 10, 34-40. [CrossRef] [PubMed]

394. Piconi, C.; Condo, S.G.; Kosmac, T. Chapter 11-Alumina- and zirconia-based ceramics for load-bearing applications. In Advanced Ceramics for Dentistry; Shen, J.Z., Kosmač, T., Eds.; Butterworth-Heinemann: Oxford, UK, 2014; pp. 219-253. 
395. Kandpal, B.C.; kumar, J.; Singh, H. Fabrication and characterisation of $\mathrm{Al}_{2} \mathrm{O}_{3} /$ aluminium alloy 6061 composites fabricated by stir casting. Mater. Today Proc. 2017, 4, 2783-2792. [CrossRef]

396. Saini, M.; Singh, Y.; Arora, P.; Arora, V.; Jain, K. Implant biomaterials: A comprehensive review. World J. Clin. Cases 2015, 3, 52-57. [CrossRef] [PubMed]

397. Sarhadi, F.; Shafiee Afarani, M.; Mohebbi-Kalhori, D.; Shayesteh, M. Fabrication of alumina porous scaffolds with aligned oriented pores for bone tissue engineering applications. Appl. Phys. A 2016, 122, 390. [CrossRef]

398. Levin, I.; Brandon, D. Metastable alumina polymorphs: Crystal structures and transition sequences. J. Am. Ceram. Soc. 1998, 81, 1995-2012. [CrossRef]

399. Rahmati, M.; Mozafari, M. Biocompatibility of alumina-based biomaterials-A review. J. Cell. Physiol. 2019, 234, 3321-3335. [CrossRef]

400. Ferraz, N.; Hong, J.; Santin, M.; Ott, M. Nanoporosity of alumina surfaces induces different patterns of activation in adhering monocytes/macrophages. Int. J. Biomater. 2010, 2010, 402715. [CrossRef]

401. Gregorová, E.; Pabst, W.; Živcová, Z.; Sedlářová, I.; Holíková, S. Porous alumina ceramics prepared with wheat flour. J. Eur. Ceram. Soc. 2010, 30, 2871-2880. [CrossRef]

402. Bartonickova, E.; Vojtisek, J.; Tkacz, J.; Pořízka, J.; Masilko, J.; Moncekova, M.; Parizek, L. Porous HA/Alumina composites intended for bone-tissue engineering. Mater. Technol. 2017, 51, 631-636. [CrossRef]

403. Leary Swan, E.E.; Popat, K.C.; Desai, T.A. Peptide-immobilized nanoporous alumina membranes for enhanced osteoblast adhesion. Biomaterials 2005, 26, 1969-1976. [CrossRef] [PubMed]

404. Ding, G.; Yang, R.; Ding, J.; Yuan, N.; Zhu, Y. Fabrication of porous anodic alumina with ultrasmall nanopores. Nanoscale Res. Lett. 2010, 5, 1257. [CrossRef] [PubMed]

405. Zaraska, L.; Jaskula, M.; Sulka, G. Porous anodic alumina layers with modulated pore diameters formed by sequential anodizing in different electrolytes. Mater. Lett. 2016, 171, 315-318. [CrossRef]

406. Porta-I-Batalla, M.; Xifré-Pérez, E.; Eckstein, C.; Ferré-Borrull, J.; Marsal, L.F. 3D Nanoporous Anodic Alumina Structures for Sustained Drug Release. Nanomaterials 2017, 7, 227. [CrossRef]

407. Vishal, P. Design and fabrication of ordered mesoporous alumina scaffold for drug delivery of poorly water soluble drug. Austin Ther. 2015, 2, 1-5.

408. Kang, H.J.; Park, S.J.; Yoo, J.B.; Kim, D.J. Controlled drug release using nanoporous anodic aluminum oxide. Solid State Phenom. 2007, 121, 709-712. [CrossRef]

409. Owens, G.J.; Singh, R.K.; Foroutan, F.; Alqaysi, M.; Han, C.-M.; Mahapatra, C.; Kim, H.-W.; Knowles, J.C. Sol-gel based materials for biomedical applications. Prog. Mater. Sci. 2016, 77, 1-79. [CrossRef]

410. Kumar Panda, S.; Dhupal, D.; Kumar Nanda, B. Experimental study on $\mathrm{Ca}_{3}\left(\mathrm{PO}_{4}\right)_{2}-\mathrm{Al}_{2} \mathrm{O}_{3}$ bio-ceramic composite using DPSS laser. Mater. Today Proc. 2018, 5, 24133-24140. [CrossRef]

411. Toloue, E.B.; Karbasi, S.; Salehi, H.; Rafienia, M. Evaluation of mechanical properties and cell viability of poly (3-Hydroxybutyrate)-Chitosan $/ \mathrm{Al}_{2} \mathrm{O}_{3}$ nanocomposite scaffold for cartilage tissue engineering. J. Med. Signals Sens. 2019, 9, 111-116.

412. Venkatesh, N.; Hanumantharaju, H.G.; Aravind, J. A Study of bio-active coating of $\mathrm{Al}_{2} \mathrm{O}_{3}$, egg and sea shell powder on Ss3161 and Ti-6Al-4V. Mater. Today Proc. 2018, 5, 22687-22693. [CrossRef]

413. Mandracci, P.; Mussano, F.; Rivolo, P.; Carossa, S. Surface treatments and functional coatings for biocompatibility improvement and bacterial adhesion reduction in dental implantology. Coatings 2016, 6, 7. [CrossRef]

414. Zhao, X.; Zhang, W.; Wang, Y.; Liu, Q.; Yang, J.; Zhang, L.; He, F. Fabrication of $\mathrm{Al}_{2} \mathrm{O}_{3}$ by anodic oxidation and hydrothermal synthesis of strong-bonding hydroxyapatite coatings on its surface. Appl. Surf. Sci. 2019, 470, 959-969. [CrossRef]

415. Rodríguez, J.P.; Ríos, S.; González, M. Modulation of the proliferation and differentiation of human mesenchymal stem cells by copper. J. Cell. Biochem. 2002, 85, 92-100. [CrossRef] [PubMed]

416. Hu, G. Copper stimulates proliferation of human endothelial cells under culture. J. Cell. Biochem. 1998, 69, 326-335. [CrossRef]

417. Cioffi, N.; Torsi, L.; Ditaranto, N.; Tantillo, G.; Ghibelli, L.; Sabbatini, L.; Bleve-Zacheo, T.; D'Alessio, M.; Zambonin, P.G.; Traversa, E. Copper nanoparticle/polymer composites with antifungal and bacteriostatic properties. Chem. Mater. 2005, 17, 5255-5262. [CrossRef]

418. Gallo, J.; Holinka, M.; Moucha, C.S. Antibacterial surface treatment for orthopaedic implants. Int. J. Mol. Sci. 2014, 15, 13849-13880. [CrossRef] 
419. Chaudhri, M.A.; Kemmler, W.; Harsch, I.; Watling, R.J. Plasma copper and bone mineral density in osteopenia: An indicator of bone mineral density in osteopenic females. Biol. Trace Elem. Res. 2009, 129, 94-98. [CrossRef]

420. Das, A.; Sudhahar, V.; Chen, G.-F.; Kim, H.W.; Youn, S.-W.; Finney, L.; Vogt, S.; Yang, J.; Kweon, J.; Surenkhuu, B.; et al. Endothelial antioxidant-1: A Key mediator of copper-dependent wound healing in vivo. Sci. Rep. 2016, 6, 33783. [CrossRef]

421. Nethi, S.K.; Das, S.; Patra, C.R.; Mukherjee, S. Recent advances in inorganic nanomaterials for wound-healing applications. Biomater. Sci. 2019, 7, 2652-2674. [CrossRef]

422. Tripathi, A.; Saravanan, S.; Pattnaik, S.; Moorthi, A.; Partridge, N.C.; Selvamurugan, N. Bio-composite scaffolds containing chitosan/nano-hydroxyapatite/nano-copper-zinc for bone tissue engineering. Int. J. Biol. Macromol. 2012, 50, 294-299. [CrossRef]

423. Azeena, S.; Subhapradha, N.; Selvamurugan, N.; Narayan, S.; Srinivasan, N.; Murugesan, R.; Chung, T.W.; Moorthi, A. Antibacterial activity of agricultural waste derived wollastonite doped with copper for bone tissue engineering. Mater. Sci. Eng. C 2017, 71, 1156-1165. [CrossRef] [PubMed]

424. Ryan, E.J.; Ryan, A.J.; González-Vázquez, A.; Philippart, A.; Ciraldo, F.E.; Hobbs, C.; Nicolosi, V.; Boccaccini, A.R.; Kearney, C.J.; O’Brien, F.J. Collagen scaffolds functionalised with copper-eluting bioactive glass reduce infection and enhance osteogenesis and angiogenesis both in vitro and in vivo. Biomaterials 2019, 197, 405-416. [CrossRef] [PubMed]

425. Alizadeh, S.; Seyedalipour, B.; Shafieyan, S.; Kheime, A.; Mohammadi, P.; Aghdami, N. Copper nanoparticles promote rapid wound healing in acute full thickness defect via acceleration of skin cell migration, proliferation, and neovascularization. Biochem. Biophys. Res. Commun. 2019, 517, 684-690. [CrossRef] [PubMed]

426. Michels, H.; Moran, W.; Michel, J. Antimicrobial properties of copper alloy surfaces, with a focus on hospital-acquired infections. Int. J. Met. 2008, 2, 47-56. [CrossRef]

427. Chen, Z.; Meng, H.; Xing, G.; Chen, C.; Zhao, Y.; Jia, G.; Wang, T.; Yuan, H.; Ye, C.; Zhao, F.; et al. Acute toxicological effects of copper nanoparticles in vivo. Toxicol. Lett. 2006, 163, 109-120. [CrossRef] [PubMed]

428. Khan, H.A.; Sakharkar, M.K.; Nayak, A.; Kishore, U.; Khan, A. Nanoparticles for biomedical applications: An overview. In Nanobiomaterials: Nanostructured Materials for Biomedical Applications, 1st ed.; Narayan, R.B.T.-N., Ed.; Woodhead Publishing: Cambridge, UK, 2017; Chapter 14, pp. 357-384.

429. Colombo, M.; Carregal-Romero, S.; Casula, M.F.; Gutiérrez, L.; Morales, M.P.; Böhm, I.B.; Heverhagen, J.T.; Prosperi, D.; Parak, W.J. Biological applications of magnetic nanoparticles. Chem. Soc. Rev. 2012, 41, 4306-4334. [CrossRef]

430. Sensenig, R.; Sapir, Y.; MacDonald, C.; Cohen, S.; Polyak, B. Magnetic nanoparticle-based approaches to locally target therapy and enhance tissue regeneration in vivo. Nanomedicine 2012, 7, 1425-1442. [CrossRef]

431. Khalil, M.I. Co-precipitation in aqueous solution synthesis of magnetite nanoparticles using iron(III) salts as precursors. Arab. J. Chem. 2015, 8, 279-284. [CrossRef]

432. Malik, M.A.; Wani, M.Y.; Hashim, M.A. Microemulsion method: A novel route to synthesize organic and inorganic nanomaterials: 1st Nano update. Arab. J. Chem. 2012, 5, 397-417. [CrossRef]

433. Daou, T.J.; Pourroy, G.; Bégin-Colin, S.; Grenèche, J.M.; Ulhaq-Bouillet, C.; Legaré, P.; Bernhardt, P.; Leuvrey, C.; Rogez, G. Hydrothermal synthesis of monodisperse magnetite nanoparticles. Chem. Mater. 2006, 18, 4399-4404. [CrossRef]

434. Takai, Z.; Mustafa, M.; Asman, S.; Sekak, K. Preparation and characterization of magnetite $\left(\mathrm{Fe}_{3} \mathrm{O}_{4}\right)$ nanoparticles by sol-gel method. Int. J. Nanoelectron. Mater. 2019, 12, 37-46.

435. Hachani, R.; Lowdell, M.; Birchall, M.; Hervault, A.; Mertz, D.; Begin-Colin, S.; Thanh, N.T.K. Polyol synthesis, functionalisation, and biocompatibility studies of superparamagnetic iron oxide nanoparticles as potential MRI contrast agents. Nanoscale 2016, 8, 3278-3287. [CrossRef]

436. Salazar-Alvarez, G.; Muhammed, M.; Zagorodni, A. Novel flow injection synthesis of iron oxide nanoparticles with narrow size distribution. Chem. Eng. Sci. 2006, 61, 4625-4633. [CrossRef]

437. Hassanjani-Roshan, A.; Vaezi, M.R.; Shokuhfar, A.; Rajabali, Z. Synthesis of iron oxide nanoparticles via sonochemical method and their characterization. Particuology 2011, 9, 95-99. [CrossRef]

438. Aivazoglou, E.; Metaxa, E.; Hristoforou, E. Microwave-assisted synthesis of iron oxide nanoparticles in biocompatible organic environment. AIP Adv. 2017, 8, 48201. [CrossRef] 
439. Starowicz, M.; Starowicz, P.; Zukrowski, J.; Przewoźnik, J.; Lemański, A.; Kapusta, C. Electrochemical synthesis of magnetic iron oxide nanoparticles with controlled size. J. Nanopart. Res. 2011, 13, 7167-7176. [CrossRef]

440. Huang, Y.; Zhang, L.; Huan, W.; Liang, X.; Liu, X.; Yang, Y. A study on synthesis and properties of $\mathrm{Fe}_{3} \mathrm{O}_{4}$ nanoparticles by solvothermal method. Glas. Phys. Chem. 2010, 36, 325-331. [CrossRef]

441. Wei, D.; Liu, Y.; Cao, L.; Fu, L.; Li, X.; Wang, Y.; Yu, G. A Magnetism-assisted chemical vapor deposition method to produce branched or iron-encapsulated carbon nanotubes. J. Am. Chem. Soc. 2007, 129, 7364-7368. [CrossRef]

442. Majidi, S.; Sehrig, F.Z.; Farkhani, S.M.; Goloujeh, M.S.; Akbarzadeh, A. Current methods for synthesis of magnetic nanoparticles. Artif. Cells Nanomed. Biotechnol. 2016, 44, 722-734. [CrossRef]

443. Karade, V.C.; Waifalkar, P.P.; Dongle, T.D.; Sahoo, S.C.; Kollu, P.; Patil, P.S.; Patil, P.B. Greener synthesis of magnetite nanoparticles using green tea extract and their magnetic properties. Mater. Res. Express 2017, 4, 96102. [CrossRef]

444. Kayal, S.; Bandyopadhyay, D.; Mandal, T.; Ramanujan, R. The flow of magnetic nanoparticles in magnetic drug targeting. RSC Adv. 2011, 1, 238-246. [CrossRef]

445. Safarik, I.; Safarikova, M. Magnetic techniques for the isolation and purification of proteins and peptides. Biomagn. Res. Technol. 2004, 2, 1-17. [CrossRef] [PubMed]

446. David, R.; Groebner, M.; Franz, W. Magnetic cell sorting purification of differentiated embryonic stem cells stably expressing truncated human CD4 as surface marker. Stem Cells 2005, 23, 477-482. [CrossRef] [PubMed]

447. Sun, C.; Lee, J.S.H.; Zhang, M. Magnetic nanoparticles in MR imaging and drug delivery. Adv. Drug Deliv. Rev. 2008, 60, 1252-1265. [CrossRef] [PubMed]

448. Kudr, J.; Haddad, Y.; Richtera, L.; Heger, Z.; Cernak, M.; Adam, V.; Zitka, O. Magnetic nanoparticles: From design and synthesis to real world applications. Nanomaterials 2017, 7, 243. [CrossRef]

449. Zhu, N.; Ji, H.; Yu, P.; Niu, J.; Bajwa, U.; Akram, M.W.; Udego, I.O.; Li, H.; Niu, X. Surface modification of magnetic iron oxide nanoparticles. Nanomaterials 2018, 8, 810. [CrossRef] [PubMed]

450. Akbarzadeh, A.; Samiei, M.; Davaran, S. Magnetic nanoparticles: Preparation, physical properties, and applications in biomedicine. Nanoscale Res. Lett. 2012, 7, 144. [CrossRef]

451. Pan, Y.; Du, X.; Zhao, F.; Xu, B. Magnetic nanoparticles for the manipulation of proteins and cells. Chem. Soc. Rev. 2012, 41, 2912-2942. [CrossRef]

452. Baroli, B.; Ennas, M.G.; Loffredo, F.; Isola, M.; Pinna, R.; López-Quintela, M.A. Penetration of Metallic Nanoparticles in Human Full-Thickness Skin. J. Investig. Dermatol. 2007, 127, 1701-1712. [CrossRef]

453. Li, Y.; Ye, D.; Li, M.; Ma, M.; Gu, N. Adaptive materials based on iron oxide nanoparticles for bone regeneration. ChemPhysChem 2018, 19, 1965-1979. [CrossRef]

454. Li, Y.; Liu, Y.-Z.; Long, T.; Yu, X.-B.; Tang, T.; Dai, K.-R.; Tian, B.; Guo, Y.-P.; Zhu, Z.-A. Mesoporous bioactive glass as a drug delivery system: Fabrication, bactericidal properties and biocompatibility. J. Mater. Sci. Mater. Med. 2013, 24, 1951-1961. [CrossRef] [PubMed]

455. Guo, Y.-J.; Wang, Y.-Y.; Chen, T.; Wei, Y.-T.; Chu, L.-F.; Guo, Y.-P. Hollow carbonated hydroxyapatite microspheres with mesoporous structure: Hydrothermal fabrication and drug delivery property. Mater. Sci. Eng. C 2013, 33, 3166-3172. [CrossRef] [PubMed]

456. Mahmoud, E.E.; Kamei, G.; Harada, Y.; Shimizu, R.; Kamei, N.; Adachi, N.; Misk, N.A.; Ochi, M. Cell magnetic targeting system for repair of severe chronic osteochondral defect in a rabbit model. Cell Transplant. 2016, 25, 1073-1083. [CrossRef] [PubMed]

457. Gilbertson, L.M.; Zimmerman, J.B.; Plata, D.L.; Hutchison, J.E.; Anastas, P.T. Designing nanomaterials to maximize performance and minimize undesirable implications guided by the Principles of Green Chemistry. Chem. Soc. Rev. 2015, 44, 5758-5777. [CrossRef]

458. Uskoković, V. Entering the era of nanoscience: Time to be so small. J. Biomed. Nanotechnol. 2013, 9, 1441-1470. [CrossRef]

459. Rizvi, S.A.A.; Saleh, A.M. Applications of nanoparticle systems in drug delivery technology. Saudi Pharm. J. 2018, 26, 64-70. [CrossRef]

460. Hasan, A.; Morshed, M.; Memic, A.; Hassan, S.; Webster, T.J.; Marei, H.E.-S. Nanoparticles in tissue engineering: Applications, challenges and prospects. Int. J. Nanomed. 2018, 13, 5637-5655. [CrossRef]

461. Singh, S.K.; Kulkarni, P.P.; Dash, D. Biomedical applications of nanomaterials: An overview. Bionanotechnology 2013, 1-32. [CrossRef] 
462. Das, S.; Mitra, S.; Khurana, S.M.P.; Debnath, N. Nanomaterials for biomedical applications. Front. Life Sci. 2013, 7, 90-98. [CrossRef]

463. Ng, C.-T.; Baeg, G.-H.; Yu, L.E.; Bay, C.-N.O. Biomedical applications of nanomaterials as therapeutics. Curr. Med. Chem. 2018, 25, 1409-1419. [CrossRef]

464. Gentile, A.; Ruffino, F.; Grimaldi, G.M. Complex-morphology metal-based nanostructures: Fabrication, characterization, and applications. Nanomaterials 2016, 6, 110. [CrossRef] [PubMed]

465. Mourdikoudis, S.; Pallares, R.M.; Thanh, N.T.K. Characterization techniques for nanoparticles: Comparison and complementarity upon studying nanoparticle properties. Nanoscale 2018, 10, 12871-12934. [CrossRef] [PubMed]

466. Jeevanandam, J.; Barhoum, A.; Chan, Y.S.; Dufresne, A.; Danquah, M.K. Review on nanoparticles and nanostructured materials: History, sources, toxicity and regulations. Beilstein J. Nanotechnol. 2018, 9, 1050-1074. [CrossRef] [PubMed]

467. Lin, P.-C.; Lin, S.; Wang, P.C.; Sridhar, R. Techniques for physicochemical characterization of nanomaterials. Biotechnol. Adv. 2014, 32, 711-726. [CrossRef] [PubMed]

468. Biener, J.; Wittstock, A.; Baumann, T.F.; Weissmüller, J.; Bäumer, M.; Hamza, A.V. Surface chemistry in nanoscale materials. Materials 2009, 2, 2404-2428. [CrossRef]

469. Williams, D.F. On the mechanisms of biocompatibility. Biomaterials 2008, 29, 2941-2953. [CrossRef]

470. Singh, A.; Elisseeff, J. Biomaterials for stem cell differentiation. J. Mater. Chem. 2010, 20, 8832-8847. [CrossRef]

471. Yang, X.; Li, Y.; Liu, X.; Zhang, R.; Feng, Q. In vitro uptake of hydroxyapatite nanoparticles and their effect on osteogenic differentiation of human mesenchymal stem cells. Stem Cells Int. 2018, 2018, 2036176. [CrossRef]

472. Lavenus, S.; Trichet, V.; Le Chevalier, S.; Hoornaert, A.; Louarn, G.; Layrolle, P. Cell differentiation and osseointegration influenced by nanoscale anodized titanium surfaces. Nanomedicine 2012, 7, 967-980. [CrossRef]

473. Somaiah, C.; Kumar, A.; Mawrie, D.; Sharma, A.; Patil, S.D.; Bhattacharyya, J.; Swaminathan, R.; Jaganathan, B.G. Collagen promotes higher adhesion, survival and proliferation of mesenchymal stem cells. PLoS ONE 2015, 10, e0145068. [CrossRef]

474. Rasouli, R.; Barhoum, A.; Uludag, H. A review of nanostructured surface and materials for dental implants: Surface coating, pattering and functionalization for improved performance. Biomater. Sci. 2018, 6, 1312-1338. [CrossRef]

475. Bertazzo, S.; Zambuzzi, W.F.; Da Silva, H.A.; Ferreira, C.V.; Bertran, C.A. Bioactivation of alumina by surface modification: A possibility for improving the applicability of alumina in bone and oral repair. Clin. Oral Implants Res. 2009, 20, 288-293. [CrossRef] [PubMed]

476. Profeta, A.C.; Huppa, C. Bioactive-glass in oral and maxillofacial surgery. Craniomaxillofac. Trauma Reconstr. 2016, 9, 1-14. [CrossRef] [PubMed]

477. Crovace, M.C.; Souza, M.T.; Chinaglia, C.R.; Peitl, O.; Zanotto, E.D. Biosilicate ${ }^{\circledR}$ _A multipurpose, highly bioactive glass-ceramic. In vitro, in vivo and clinical trials. J. Non. Cryst. Solids 2016, 432, 90-110. [CrossRef]

478. Kargozar, S.; Montazerian, M.; Fiume, E.; Baino, F. Multiple and promising applications of strontium (Sr)-containing bioactive glasses in bone tissue engineering. Front. Bioeng. Biotechnol. 2019, 7, 161. [CrossRef] [PubMed]

479. Baino, F.; Vitale-Brovarone, C. Three-dimensional glass-derived scaffolds for bone tissue engineering: Current trends and forecasts for the future. J. Biomed. Mater. Res. Part A 2011, 97, 514-535. [CrossRef]

480. Tautzenberger, A.; Kovtun, A.; Ignatius, A. Nanoparticles and their potential for application in bone. Int. J. Nanomed. 2012, 7, 4545-4557. [CrossRef]

481. Kumar, P.; Dehiya, B.S.; Sindhu, A. Ibuprofen-loaded CTS/nHA/nBG Scaffolds for the applications of hard tissue engineering. Iran. Biomed. J. 2019, 23, 190-199. [CrossRef]

482. Faraji, A.H.; Wipf, P. Nanoparticles in cellular drug delivery. Bioorganic Med. Chem. 2009, 17, $2950-2962$. [CrossRef]

483. Kong, G.; Braun, R.D.; Dewhirst, M.W. Hyperthermia enables tumor-specific nanoparticle delivery: Effect of particle size hyperthermia enables tumor-specific nanoparticle delivery: Effect of particle size 1. Cancer Res. 2000, 60, 4440-4445.

484. Trewyn, B.G.; Slowing, I.I.; Chen, H.; Lin, V.S. Synthesis and functionalization of a mesoporous silica nanoparticle based on the sol-gel process and applications in controlled release. Acc. Chem. Res. 2007, 40, 846-853. [CrossRef] [PubMed] 
485. Kumari, A.; Singla, R.; Guliani, A.; Yadav, S.K. Nanoencapsulation for drug delivery. EXCLI J. 2014, 13, 265-286. [PubMed]

486. Mahapatro, A.; Singh, D.K. Biodegradable nanoparticles are excellent vehicle for site directed in-vivo delivery of drugs and vaccines. J. Nanobiotechnol. 2011, 9, 55. [CrossRef] [PubMed]

487. Riley, M.K.; Vermerris, W. Recent advances in nanomaterials for gene delivery-A review. Nanomaterials 2017, 7, 94. [CrossRef]

488. Ylä-Herttuala, S. Endgame: Glybera finally recommended for approval as the first gene therapy drug in the European Union. Mol. Ther. 2012, 20, 1831-1832. [CrossRef]

489. Loh, X.J.; Lee, T.-C.; Dou, Q.; Deen, G.R. Utilising inorganic nanocarriers for gene delivery. Biomater. Sci. 2016, 4, 70-86. [CrossRef]

490. Zhao, Y.; Huang, L. Lipid nanoparticles for gene delivery. Adv. Genet. 2014, 88, 13-36.

491. Martin, B.; Sainlos, M.; Aissaoui, A.; Oudrhiri, N.; Hauchecorne, M.; Vigneron, J.-P.; Lehn, J.-M.; Lehn, P. The design of cationic lipids for gene delivery. Curr. Pharm. Des. 2005, 11, 375-394. [CrossRef]

492. Nordling-David, M.M.; Golomb, G. Gene delivery by liposomes. Isr. J. Chem. 2013, 53, 737-747. [CrossRef]

493. Ropert, C. Liposomes as a gene delivery system. Braz. J. Med. Biol. Res. 1999, 32, 163-169. [CrossRef]

494. Zylberberg, C.; Gaskill, K.; Pasley, S.; Matosevic, S. Engineering liposomal nanoparticles for targeted gene therapy. Gene Ther. 2017, 24, 441-452. [CrossRef] [PubMed]

495. Santander-Ortega, M.J.; Lozano, M.V.; Uchegbu, I.F.; Schätzlein, A.G. 6-Dendrimers for gene therapy. In Polymers and Nanomaterials for Gene Therapy; Narain, R., Ed.; Woodhead Publishing: Cambridge, UK, 2016; pp. 113-146.

496. Eliyahu, H.; Barenholz, Y.; Domb, A.J. Polymers for DNA delivery. Molecules 2005, 10, 34-64. [CrossRef] [PubMed]

497. Sharma, M.R.R.; Rekha, C.P. Polymers for gene delivery: Current status and future perspectives. Recent Patents DNA Gene Seq. 2012, 6, 98-107.

498. Zhao, H.; Ding, R.; Zhao, X.; Li, Y.; Qu, L.; Pei, H.; Yildirimer, L.; Wu, Z.; Zhang, W. Graphene-based nanomaterials for drug and/or gene delivery, bioimaging, and tissue engineering. Drug Discov. Today 2017, 22, 1302-1317. [CrossRef] [PubMed]

499. Imani, R.; Mohabatpour, F.; Mostafavi, F. Graphene-based nano-carrier modifications for gene delivery applications. Carbon N. Y. 2018, 140, 569-591. [CrossRef]

500. Dolatabadi, J.E.N.; Omid, Y.O.; Losic, D. Carbon nanotubes as an advanced drug and gene delivery nanosystem. Curr. Nanosci. 2011, 7, 297-314. [CrossRef]

501. Ramos-Perez, V.; Cifuentes, A.; Coronas, N.; de Pablo, A.; Borrós, S. Modification of carbon nanotubes for gene delivery vectors. In Nanomaterial Interfaces in Biology: Methods and Protocols; Bergese, P., Hamad-Schifferli, K., Eds.; Humana Press: Totowa, NJ, USA, 2013; pp. 261-268.

502. Keasberry, N.A.; Yapp, C.W.; Idris, A. Mesoporous silica nanoparticles as a carrier platform for intracellular delivery of nucleic acids. Biochemistry 2017, 82, 655-662. [CrossRef]

503. Mendes, R.; Fernandes, A.R.; Baptista, P.V. Gold nanoparticle approach to the selective delivery of gene silencing in cancer-The case for combined delivery? Genes 2017, 8, 94. [CrossRef]

504. Ding, Y.; Jiang, Z.; Saha, K.; Kim, C.S.; Kim, S.T.; Landis, R.F.; Rotello, V.M. Gold nanoparticles for nucleic acid delivery. Mol. Ther. 2014, 22, 1075-1083. [CrossRef]

505. Majidi, S.; Zeinali Sehrig, F.; Samiei, M.; Milani, M.; Abbasi, E.; Dadashzadeh, K.; Akbarzadeh, A. Magnetic nanoparticles: Applications in gene delivery and gene therapy. Artif. Cells Nanomed. Biotechnol. 2016, 44, 1186-1193. [CrossRef]

506. McBain, S.C.; Yiu, H.H.P.; Dobson, J. Magnetic nanoparticles for gene and drug delivery. Int. J. Nanomed. 2008, 3, 169-180.

507. Giacca, M.; Zacchigna, S. Virus-mediated gene delivery for human gene therapy. J. Control. Release 2012, 161, 377-388. [CrossRef] [PubMed]

508. Domvri, K.; Zarogoulidis, P.; Porpodis, K.; Koffa, M.; Lambropoulou, M.; Kakolyris, S.; Minadakis, G.; Zarogoulidis, K.; Chatzaki, E. Gene therapy in liver diseases: State-of-the-art and future perspectives. Curr. Gene Ther. 2012, 12, 463-483. [CrossRef] [PubMed]

509. Nienhuis, A.W.; Nathwani, A.C.; Davidoff, A.M. Gene therapy for hemophilia. Mol. Ther. 2017, 25, $1163-1167$. [CrossRef] 
510. Luo, J.; Sun, M.; Kang, Q.; Peng, Y.; Jiang, W.; Luu, H.; Luo, Q.; Park, J.; Li, Y.; Haydon, R. Gene therapy for bone regeneration. Curr. Gene Ther. 2005, 5, 167-179. [CrossRef]

511. Pensak, M.J.; Lieberman, J.R. Gene therapy for bone regeneration. Curr. Pharm. Des. 2013, 19, 3466-3473. [CrossRef]

512. Shapiro, G.; Lieber, R.; Gazit, D.; Pelled, G. Recent advances and future of gene therapy for bone regeneration. Curr. Osteoporos. Rep. 2018, 16, 504-511. [CrossRef]

513. De Jong, W.H.; Borm, P.J.A. Drug delivery and nanoparticles:applications and hazards. Int. J. Nanomed. 2008, 3, 133-149. [CrossRef]

514. Navya, P.N.; Daima, H.K. Rational engineering of physicochemical properties of nanomaterials for biomedical applications with nanotoxicological perspectives. Nano Converg. 2016, 3, 1. [CrossRef]

515. Sperling, R.A.; Parak, W.J. Surface modification, functionalization and bioconjugation of colloidal inorganic nanoparticles. Philos. Trans. R. Soc. A Math. Phys. Eng. Sci. 2010, 368, 1333-1383. [CrossRef]

516. Liu, C.; Zhang, N. Chapter 13-Nanoparticles in gene therapy: Principles, prospects, and challenges. In Nanoparticles in Translational Science and Medicine; Villaverde, A.B.T.-P., Ed.; Academic Press: Cambridge, MA, USA, 2011; Volume 104, pp. 509-562.

517. Islam, M.; Park, T.-E.; Singh, B.; Maharjan, S.; Firdous, J.; Kang, S.-K.; Yun, C.-H.; Choi, Y.; Cho, C. Major degradable polycations as carriers for DNA and siRNA. J. Control. Release 2014, 193, 74-89. [CrossRef] [PubMed]

518. Wang, Y.; Li, Z.; Weber, T.J.; Hu, D.; Lin, C.-T.; Li, J.; Lin, Y. In Situ Live Cell Sensing of multiple nucleotides exploiting DNA/RNA aptamers and graphene oxide nanosheets. Anal. Chem. 2013, 85, 6775-6782. [CrossRef] [PubMed]

519. Keles, E.; Song, Y.; Du, D.; Dong, W.-J.; Lin, Y. Recent progress in nanomaterials for gene delivery applications. Biomater. Sci. 2016, 4, 1291-1309. [CrossRef] [PubMed]

520. Radu, D.R.; Lai, C.-Y.; Jeftinija, K.; Rowe, E.W.; Jeftinija, S.; Lin, V.S.-Y. A Polyamidoamine dendrimer-capped mesoporous silica nanosphere-based gene transfection reagent. J. Am. Chem. Soc. 2004, 126, 13216-13217. [CrossRef] [PubMed]

521. Palmerston Mendes, L.; Pan, J.; Torchilin, V.P. Dendrimers as nanocarriers for nucleic acid and drug delivery in cancer therapy. Molecules 2017, 22, 1401. [CrossRef] [PubMed]

522. Kukowska-Latallo, J.F.; Bielinska, A.U.; Johnson, J.; Spindle, R.; Tomalia, D.A.; Baker, J.R. Efficient transfer of genetic material into mammalian cells using starburst polyamidoamine dendrimers. Proc. Natl. Acad. Sci. USA 1996, 93, 4897-4902. [CrossRef] [PubMed]

523. Chen, L.; Deng, H.; Cui, H.; Fang, J.; Zuo, Z.; Deng, J.; Li, Y.; Wang, X.; Zhao, L. Inflammatory responses and inflammation-associated diseases in organs. Oncotarget 2017, 9, 7204-7218. [CrossRef] [PubMed]

524. Busscher, H.J.; van der Mei, H.C.; Subbiahdoss, G.; Jutte, P.C.; van den Dungen, J.J.A.M.; Zaat, S.A.J.; Schultz, M.J.; Grainger, D.W. Biomaterial-associated infection: Locating the finish line in the race for the surface. Sci. Transl. Med. 2012, 4, 153rv10. [CrossRef]

525. Buhmann, M.T.; Stiefel, P.; Maniura-Weber, K.; Ren, Q. In vitro biofilm models for device-related infections. Trends Biotechnol. 2016, 34, 945-948. [CrossRef]

526. Lin, G.-L.; McGinley, J.P.; Drysdale, S.B.; Pollard, A.J. Epidemiology and immune pathogenesis of viral sepsis. Front. Immunol. 2018, 9, 2147. [CrossRef]

527. Oliveira, W.F.; Silva, P.M.S.; Silva, R.C.S.; Silva, G.M.M.; Machado, G.; Coelho, L.C.B.B.; Correia, M.T.S. Staphylococcus aureus and Staphylococcus epidermidis infections on implants. J. Hosp. Infect. 2018, 98, 111-117. [CrossRef] [PubMed]

528. Holzapfel, B.M.; Reichert, J.C.; Schantz, J.-T.; Gbureck, U.; Rackwitz, L.; Nöth, U.; Jakob, F.; Rudert, M.; Groll, J.; Hutmacher, D.W. How smart do biomaterials need to be? A translational science and clinical point of view. Adv. Drug Deliv. Rev. 2013, 65, 581-603. [CrossRef] [PubMed]

529. Ng, V. Risk of Disease Transmission With Bone Allograft. Orthopedics 2012, 35, 679-681. [CrossRef] [PubMed]

530. Jun, I.; Han, H.-S.; Edwards, J.R.; Jeon, H. Electrospun Fibrous scaffolds for tissue engineering: Viewpoints on architecture and fabrication. Int. J. Mol. Sci. 2018, 19, 745. [CrossRef]

531. Gong, T.; Xie, J.; Liao, J.; Zhang, T.; Lin, S.; Lin, Y. Nanomaterials and bone regeneration. Bone Res. 2015, 3 , 1-7. [CrossRef]

532. Gopalu, K.; Rangaraj, S.; Venkatachalam, R.; Kannan, N. Influence of $\mathrm{ZrO}_{2}, \mathrm{SiO}_{2}, \mathrm{Al}_{2} \mathrm{O}_{3}$ and $\mathrm{TiO}_{2}$ nanoparticles on maize seed germination under different growth conditions. IET Nanobiotechnol. 2016, 10, 171-177. 
533. Dhandayuthapani, B.; Yoshida, Y.; Maekawa, T.; Kumar, D.S. Polymeric scaffolds in tissue engineering application: A review. Int. J. Polym. Sci. 2011, 2011, 290602. [CrossRef]

534. Mozumder, M.S.; Zhu, J.; Perinpanayagam, H. Titania-polymeric powder coatings with nano-topography support enhanced human mesenchymal cell responses. J. Biomed. Mater. Res. Part A 2012, 100, 2695-2709. [CrossRef]

535. Trentler, T.J.; Denler, T.E.; Bertone, J.F.; Agrawal, A.; Colvin, V.L. Synthesis of $\mathrm{TiO}_{2}$ nanocrystals by nonhydrolytic solution-based reactions. J. Am. Chem. Soc. 1999, 121, 1613-1614. [CrossRef]

536. Hussian, H.A.R.A.; Hassan, M.A.M.; Agool, I.R. Synthesis of titanium dioxide $\left(\mathrm{TiO}_{2}\right)$ nanofiber and nanotube using different chemical method. Optik 2016, 127, 2996-2999. [CrossRef]

537. Shi, H.; Magaye, R.; Castranova, V.; Zhao, J. Titanium dioxide nanoparticles: A review of current toxicological data. Part. Fibre Toxicol. 2013, 10, 15. [CrossRef] [PubMed]

538. Ashkarran, A.A.; Fakhari, M.; Hamidinezhad, H.; Haddadi, H.; Nourani, M.R. TiO 2 nanoparticles immobilized on carbon nanotubes for enhanced visible-light photo-induced activity. J. Mater. Res. Technol. 2015, 4, 126-132. [CrossRef]

539. Tsuchiya, H.; Macak, J.M.; Müller, L.; Kunze, J.; Müller, F.; Greil, P.; Virtanen, S.; Schmuki, P. Hydroxyapatite growth on anodic $\mathrm{TiO}_{2}$ nanotubes. J. Biomed. Mater. Res. Part A 2006, 77, 534-541. [CrossRef] [PubMed]

540. Inzunza, D.; Covarrubias, C.; Von Marttens, A.; Leighton, Y.; Carvajal, J.C.; Valenzuela, F.; Diaz-Dosque, M.; Méndez, N.; Martínez, C.; Pino, A.M.; et al. Synthesis of nanostructured porous silica coatings on titanium and their cell adhesive and osteogenic differentiation properties. J. Biomed. Mater. Res. Part A 2013, 102, 37-48. [CrossRef]

541. Assad, M.; Chernyshov, A.; Leroux, M.; Rivard, C. A new porous titanium-nickel alloy: Part 1. Cytotoxicity and genotoxicity evaluation. Biomed. Mater. Eng. 2002, 12, 225-237.

542. Gu, Y.W.; Khor, K.; Pan, D.; Cheang, P. Activity of plasma sprayed yttria stabilized zirconia reinforced hydroxyapatite/Ti-6Al-4V composite coatings in simulated body fluid. Biomaterials 2004, 25, 3177-3185. [CrossRef]

543. Maschhoff, P.M.; Geilich, B.M.; Webster, T.J. Greater fibroblast proliferation on an ultrasonicated ZnO/PVC nanocomposite material. Int. J. Nanomed. 2014, 9, 257-263.

544. Pei, B.; Wang, W.; Dunne, N.; Li, X. Applications of carbon nanotubes in bone tissue regeneration and engineering: Superiority, concerns, current advancements, and prospects. Nanomaterials 2019, 9, 1501. [CrossRef] [PubMed]

545. Subbiah, R.; Du, P.; Van, S.Y.; Suhaeri, M.; Hwang, M.P.; Lee, K.; Kwideok, P. Fibronectin-tethered graphene oxide as an artificial matrix for osteogenesis. Biomed. Mater. 2014, 9, 65003. [CrossRef] [PubMed]

546. Zhao, C.; Lu, X.; Zanden, Z.; Liu, J. The promising application of graphene oxide as coating materials in orthopedic implants: Preparation, characterization and cell behavior. Biomed. Mater. 2015, 10, 15019. [CrossRef] [PubMed]

547. Al-Jumaili, A.; Alancherry, S.; Bazaka, K.; Jacob, M.V. Review on the antimicrobial properties of carbon nanostructures. Materials 2017, 10, 1066. [CrossRef] [PubMed]

548. Nishida, E.; Miyaji, H.; Takita, H.; Kanayama, I.; Tsuji, M.; Akasaka, T.; Sugaya, T.; Sakagami, R.; Kawanami, M. Graphene oxide coating facilitates the bioactivity of scaffold material for tissue engineering. Jpn. J. Appl. Phys. 2014, 53, 06JD04. [CrossRef]

549. Guazzo, R.; Gardin, C.; Bellin, G.; Sbricoli, L.; Ferroni, L.; Ludovichetti, F.S.; Piattelli, A.; Antoniac, I.; Bressan, E.; Zavan, B. Graphene-based nanomaterials for tissue engineering in the dental field. Nanomaterials 2018, 8, 349. [CrossRef] [PubMed]

550. Vera-Sánchez, M.; Aznar-Cervantes, S.; Jover, E.; García-Bernal, D.; Oñate-Sánchez, R.; Hernández-Romero, D.; Moraleda, J.M.; Collado-González, M.; Rodríguez-Lozano, F.J.; Cenis, J. Silk-fibroin and graphene oxide composites promote human periodontal ligament stem cell spontaneous differentiation into osteo/cementoblast-like cells. Stem Cells Dev. 2016, 25, 1742-1754. [CrossRef] [PubMed]

551. Ghassemi, T.; Shahroodi, A.; Ebrahimzadeh, M.H.; Mousavian, A.; Movaffagh, J.; Moradi, A. Current concepts in scaffolding for bone tissue engineering. Arch. Bone Jt. Surg. 2018, 6, 90-99.

552. Farack, J.; Wolf-Brandstetter, C.; Glorius, S.; Nies, B.; Standke, G.; Quadbeck, P.; Worch, H.; Scharnweber, D. The effect of perfusion culture on proliferation and differentiation of human mesenchymal stem cells on biocorrodible bone replacement material. Mater. Sci. Eng. B 2011, 176, 1767-1772. [CrossRef] 
553. Zhang, P.; Wu, T.; Kong, J.-L. In situ monitoring of intracellular controlled drug release from mesoporous silica nanoparticles coated with pH-responsive charge-reversal polymer. ACS Appl. Mater. Interfaces 2014, 6, 17446-17453. [CrossRef]

554. Kim, S.-S.; Ahn, K.-M.; Park, M.S.; Lee, J.-H.; Choi, C.Y.; Kim, B.-S. A poly(lactide-co-glycolide)/hydroxyapatite composite scaffold with enhanced osteoconductivity. J. Biomed. Mater. Res. Part A 2007, 80, 206-215. [CrossRef]

555. Rider, P.; Kačarević, Ž.P.; Alkildani, S.; Retnasingh, S.; Barbeck, M. Bioprinting of tissue engineering scaffolds. J. Tissue Eng. 2018, 9, 2041731418802090. [CrossRef]

556. Park, J.W.; Hwang, S.R.; Yoon, I.-S. Advanced growth factor delivery systems in wound management and skin regeneration. Molecules 2017, 22, 1259. [CrossRef]

557. Kleinman, H.K.; Philp, D.; Hoffman, M.P. Role of the extracellular matrix in morphogenesis. Curr. Opin. Biotechnol. 2003, 14, 526-532. [CrossRef] [PubMed]

558. Lee, E.J.; Kasper, F.K.; Mikos, A.G. Biomaterials for tissue engineering. Ann. Biomed. Eng. 2014, $42,323-337$. [CrossRef] [PubMed]

559. Sato, M.; Webster, T.J.; Sato, M.; Webster, T.J. Nanobiotechnology: Implications for the future of nanotechnology in orthopedic applications Nanobiotechnology: Implications for the future of nanotechnology in orthopedic applications. Expert Rev. Med. Devices 2004, 1, 105-114. [CrossRef] [PubMed]

560. Demais, V.; Audrain, C.; Mabilleau, G.; Chappard, D.; Baslé, M.F. Diversity of bone matrix adhesion proteins modulates osteoblast attachment and organization of actin cytoskeleton. Morphologie 2014, 98, 53-64. [CrossRef] [PubMed]

561. Tran, N.; Webster, T.J. Increased osteoblast functions in the presence of hydroxyapatite-coated iron oxide nanoparticles. Acta Biomater. 2011, 7, 1298-1306. [CrossRef] [PubMed]

562. Smith, L.A.; Ma, P.X. Nano-fibrous scaffolds for tissue engineering. Colloids Surf. B Biointerfaces 2004, 39, 125-131. [CrossRef] [PubMed]

563. Tuzlakoglu, K.; Bolgen, N.; Salgado, A.J.; Gomes, M.E.; Piskin, E.; Reis, R.L. Nano- and micro-fiber combined scaffolds: A new architecture for bone tissue engineering. J. Mater. Sci. Mater. Med. 2005, 16, 1099-1104. [CrossRef]

564. Shin, M.; Yoshimoto, H.; Vacanti, J.P. In vivo bone tissue engineering using mesenchymal stem cells on a novel electrospun nanofibrous scaffold. Tissue Eng. 2004, 10, 33-41. [CrossRef]

565. Li, W.J.; Tuli, R.; Huang, X.; Laquerriere, P.; Tuan, R.S. Multilineage differentiation of human mesenchymal stem cells in a three-dimensional nanofibrous scaffold. Biomaterials 2005, 26, 5158-5166. [CrossRef]

566. Li, W.J.; Tuli, R.; Okafor, C.; Derfoul, A.; Danielson, K.G.; Hall, D.J.; Tuan, R.S. A three-dimensional nanofibrous scaffold for cartilage tissue engineering using human mesenchymal stem cells. Biomaterials 2005, 26, 599-609. [CrossRef]

567. Woo, K.M.; Chen, V.J.; Ma, P.X. Nano-fibrous scaffolding architecture selectively enhances protein adsorption contributing to cell attachment. J. Biomed. Mater. Res. 2003, 67, 531-537. [CrossRef] [PubMed]

568. Woo, K.M.; Jun, J.H.; Chen, V.J.; Seo, J.; Baek, J.H.; Ryoo, H.M.; Kim, G.S.; Somerman, M.J.; Ma, P.X. Nano-fibrous scaffolding promotes osteoblast differentiation and biomineralization. Biomaterials 2007, 28, 335-343. [CrossRef]

569. Bhattarai, N.; Edmondson, D.; Veiseh, O.; Matsen, F.A.; Zhang, M. Electrospun chitosan-based nanofibers and their cellular compatibility. Biomaterials 2005, 26, 6176-6184. [CrossRef] [PubMed]

570. Zhang, L.; Wang, Z.; Xu, C.; Li, Y.; Gao, J.; Wang, W.; Liu, Y. High strength graphene oxide/polyvinyl alcohol composite hydrogels. J. Mater. Chem. 2011, 21, 10399-10406. [CrossRef]

571. Goenka, S.; Sant, V.; Sant, S. Graphene-based nanomaterials for drug delivery and tissue engineering. J. Control. Release 2014, 173, 75-88. [CrossRef] [PubMed]

572. Yu, M.F.; Lourie, O.; Dyer, M.J.; Moloni, K.; Kelly, T.; Ruoff, R. Strength and breaking mechanism of multiwalled carbon nanotubes under tensile load. Science 2000, 287, 637-640. [CrossRef]

573. Kim, S.-S.; Sun Park, M.; Gwak, S.-J.; Choi, C.; Kim, B.-S. Accelerated bonelike apatite growth on porous polymer/ceramic composite scaffolds in vitro. Tissue Eng. 2006, 12, 2997-3006. [CrossRef]

574. Okamoto, M.; John, B. Synthetic biopolymer nanocomposites for tissue engineering scaffolds. Prog. Polym. Sci. 2013, 38, 1487-1503. [CrossRef]

575. Hench, L.L. Bioceramics: From concept to clinic. J. Am. Ceram. Soc. 1991, 74, 1487-1510. [CrossRef] 
576. Wei, B.; Yao, Q.; Guo, Y.; Mao, F.; Liu, S.; Xu, Y.; Wang, L. Three-dimensional polycaprolactone-hydroxyapatite scaffolds combined with bone marrow cells for cartilage tissue engineering. J. Biomater. Appl. 2015, 30, 160-170. [CrossRef]

577. Wei, G.; Ma, P.X. Structure and properties of nano-hydroxyapatite/polymer composite scaffolds for bone tissue engineering. Biomaterials 2004, 25, 4749-4757. [CrossRef] [PubMed]

578. Du, C.; Cui, F.-Z.; Feng, Q.; Zhu, X.D.; Groot, K. Tissue response to nano-hydroxyapatite/collagen composite implants in marrow cavity. J. Biomed. Mat. Res. 1998, 42, 540-548. [CrossRef]

579. Li, Z.; Yubao, L.; Aiping, Y.; Xuelin, P.; Xuejiang, W.; Xiang, Z. Preparation and in vitro investigation of chitosan/nano-hydroxyapatite composite used as bone substitute materials. J. Mater. Sci. Mater. Med. 2005, 16, 213-219. [CrossRef] [PubMed]

580. Jiang, W.G.; Sanders, A.J.; Katoh, M.; Ungefroren, H.; Gieseler, F.; Prince, M.; Thompson, S.K.; Zollo, M.; Spano, D.; Dhawan, P.; et al. Tissue invasion and metastasis: Molecular, biological and clinical perspectives. Semin. Cancer Biol. 2015, 35, S244-S275. [CrossRef]

581. Srinivasan, M.; Rajabi, M.A.; Mousa, S. Chapter 3-Nanobiomaterials in cancer therapy. In Nanobiomaterials in Cancer Therapy; Grumezescu, A.M., Ed.; William Andrew Publishing: Norwich, NY, USA, 2016; pp. 57-89.

582. Hernandez, R.K.; Wade, S.W.; Reich, A.; Pirolli, M.; Liede, A.; Lyman, G.H. Incidence of bone metastases in patients with solid tumors: Analysis of oncology electronic medical records in the United States. BMC Cancer 2018, 18, 44. [CrossRef]

583. Adjei, I.M.; Temples, M.N.; Brown, S.B.; Sharma, B. Targeted nanomedicine to treat bone metastasis. Pharmaceutics 2018, 10, 205. [CrossRef]

584. Serafini, A.N. Therapy of metastatic bone pain. J. Nucl. Med. 2001, 42, 895-906.

585. Auffinger, B.; Morshed, R.; Tobias, A.; Cheng, Y.; Ahmed, A.U.; Lesniak, M.S. Drug-loaded nanoparticle systems and adult stem cells: A potential marriage for the treatment of malignant glioma? Oncotarget 2013, 4, 378-396. [CrossRef]

586. Brannon-Peppas, L.; Blanchette, J.O. Nanoparticle and targeted systems for cancer therapy. Adv. Drug Deliv. Rev. 2004, 56, 1649-1659. [CrossRef]

587. Chu, K.F.; Dupuy, D.E. Thermal ablation of tumours: Biological mechanisms and advances in therapy. Nat. Rev. Cancer 2014, 14, 199-208. [CrossRef]

588. Nichols, J.W.; Bae, Y.H. EPR: Evidence and fallacy. J. Control. Release 2014, 190, 451-464. [CrossRef] [PubMed]

589. Navya, P.N.; Kaphle, A.; Srinivas, S.P.; Bhargava, S.K.; Rotello, V.M.; Daima, H.K. Current trends and challenges in cancer management and therapy using designer nanomaterials. Nano Converg. 2019, 6, 23. [CrossRef] [PubMed]

(C) 2020 by the authors. Licensee MDPI, Basel, Switzerland. This article is an open access article distributed under the terms and conditions of the Creative Commons Attribution (CC BY) license (http://creativecommons.org/licenses/by/4.0/). 